\title{
MAGMATIC AND STRUCTURAL FRAMEWORK OF PGE AND OTHER MINERALIZATION IN NORTHWESTERN WRANGELLIA, CENTRAL ALASKA
}

Evan Twelker, Lauren L. Lande, Rainer J. Newberry, Alicja Wypych, Karri R. Sicard, and Lawrence K. Freeman
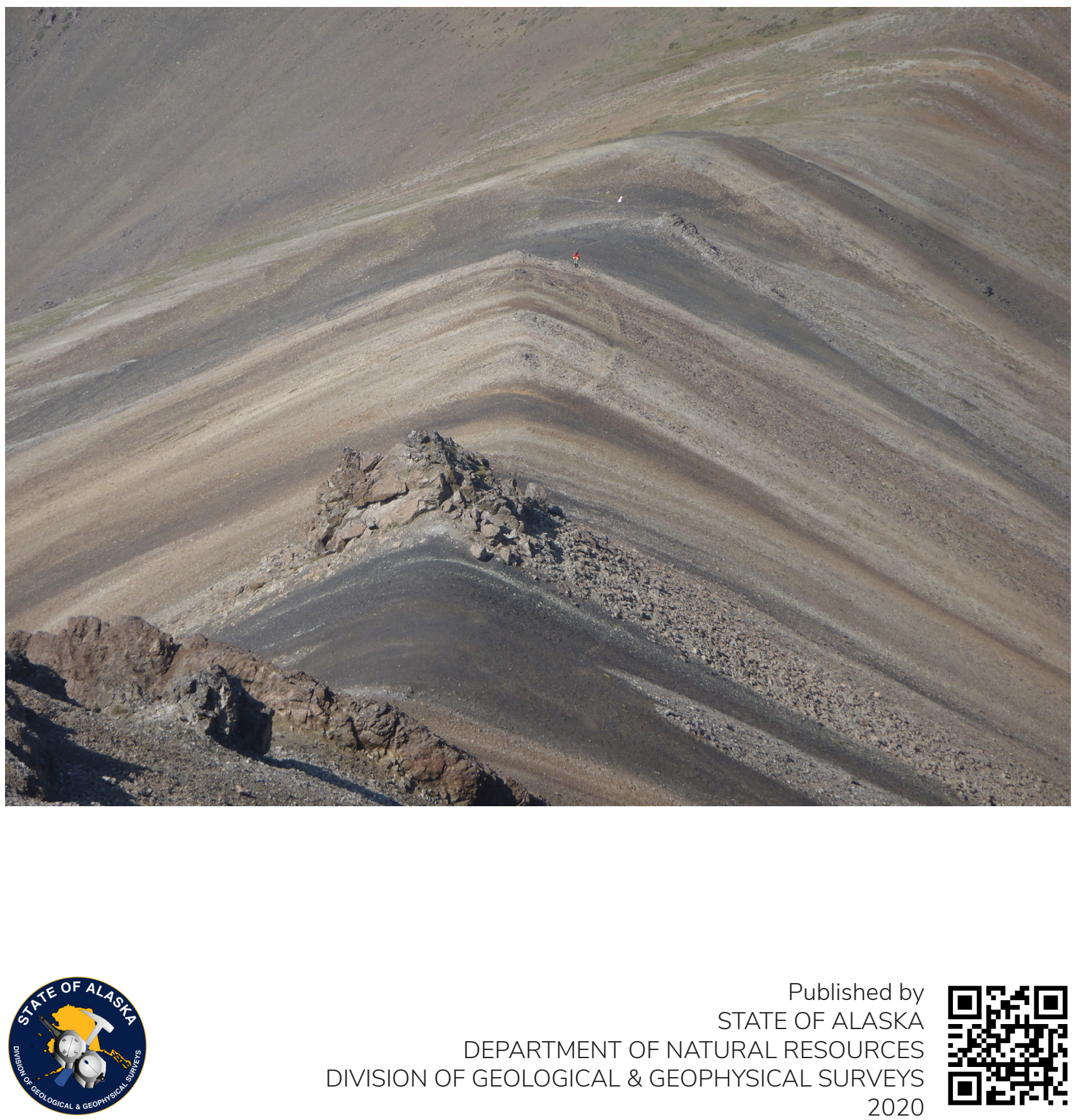

Published by STATE OF ALASKA 
Cover. Alaska Division of Geological \& Geophysical Surveys geologist Alicja Wypych traverses a ridgeline exposure of the Late Triassic Butte Creek mafic-ultramafic intrusive complex in the northwestern Talkeetna Mountains. Photograph by Evan Twelker. 


\section{MAGMATIC AND STRUCTURAL FRAMEWORK OF PGE AND OTHER MINERALIZATION IN NORTHWESTERN WRANGELLIA, CENTRAL ALASKA}

Evan Twelker, Lauren L. Lande, Rainer J. Newberry, Alicja Wypych, Karri R. Sicard, and Lawrence K. Freeman

Report of Investigation 2020-6

State of Alaska

Department of Natural Resources

Division of Geological \& Geophysical Surveys 


\section{STATE OF ALASKA}

Mike Dunleavy, Governor

\section{DEPARTMENT OF NATURAL RESOURCES}

Corri A. Feige, Commissioner

\section{DIVISION OF GEOLOGICAL \& GEOPHYSICAL SURVEYS}

Steve Masterman, State Geologist and Director

Publications produced by the Division of Geological \&

Geophysical Surveys (DGGS) are available for free download

from the DGGS website (dggs.alaska.gov). Publications on

hard-copy or digital media can be examined or purchased in

the Fairbanks office:

Alaska Division of Geological \& Geophysical Surveys

3354 College Rd., Fairbanks, Alaska 99709-3707

Phone: (907) 451-5010 Fax (907) 451-5050

dggspubs@alaska.gov|dggs.alaska.gov

\section{DGGS publications are also available at:}

Alaska State Library,

Historical Collections \& Talking Book Center

395 Whittier Street

Juneau, Alaska 99811

Alaska Resource Library and Information Services (ARLIS)

3150 C Street, Suite 100

Anchorage, Alaska 99503

\section{Suggested citation:}

Twelker, Evan, Lande, L.L., Newberry, R.J., Wypych, Alicja, Sicard, K.R., and Freeman, L.K., 2020, Magmatic and structural framework of PGE and other mineralization in northwestern Wrangellia, Central Alaska: Alaska Division of Geological \& Geophysical Surveys Report of Investigation 2020-6, 72 p.

http://doi.org/10.14509/30468
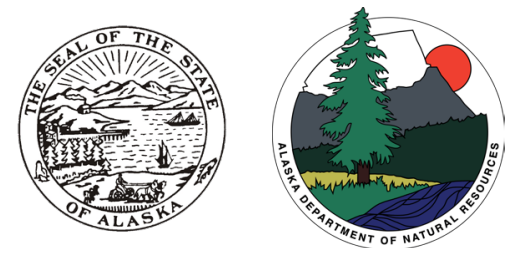


\section{Contents}

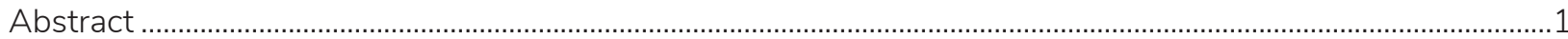

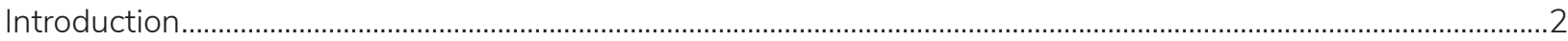

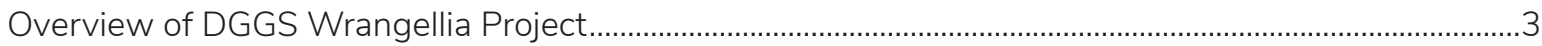

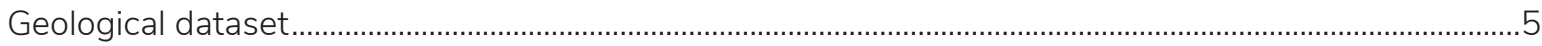

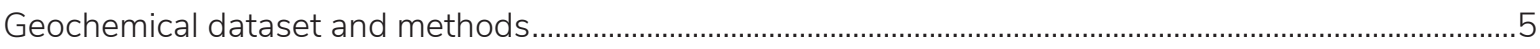

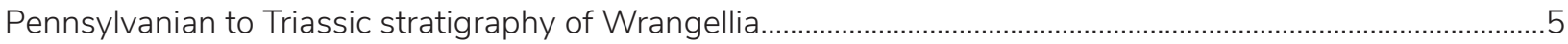

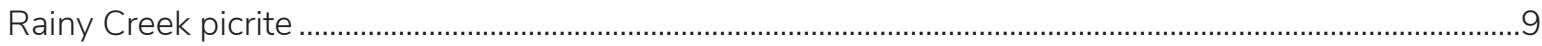

Clearwater metamorphic rocks................................................................................................................... 10

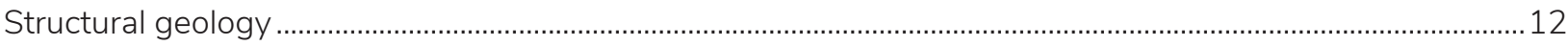

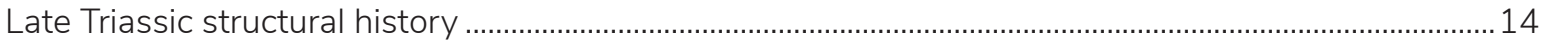

Northwest-vergent thrust faulting in the Talkeetna Mountains.................................................................... 15

Talkeetna suture zone and parallel structures in the central Talkeetna Mountains....................................16

South-vergent thrust faulting in the southern Alaska Range ....................................................................... 18

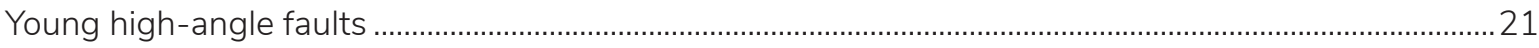

Magmatic-geochemical framework of Ni-Cu-Co-PGE mineralization .................................................................2

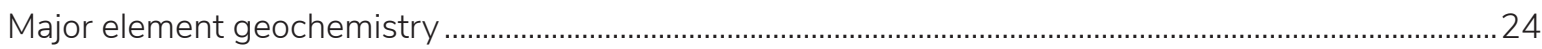

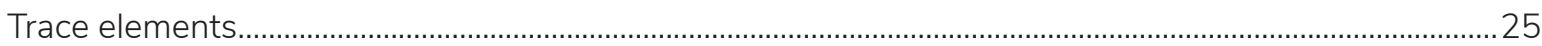

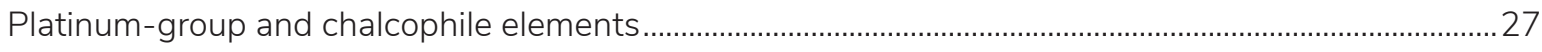

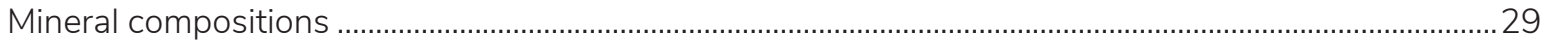

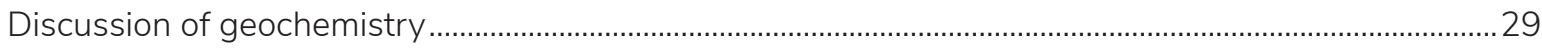

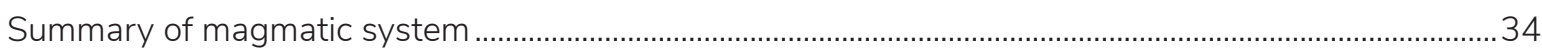

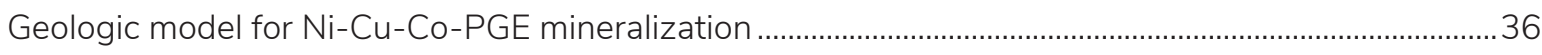

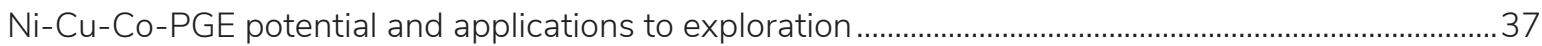

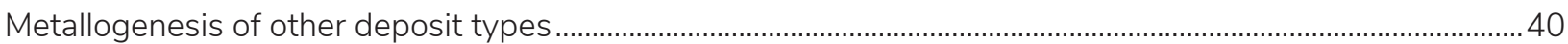

Basalt- and sediment-hosted copper mineralization ......................................................................................40

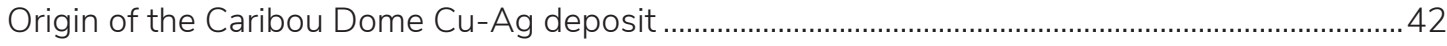

Mineralization related to intrusions other than Late Triassic....................................................................... 43

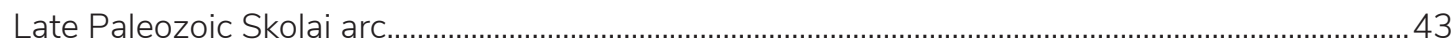

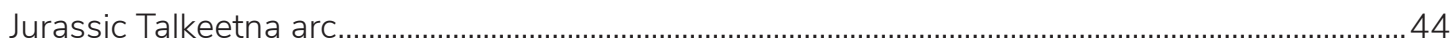

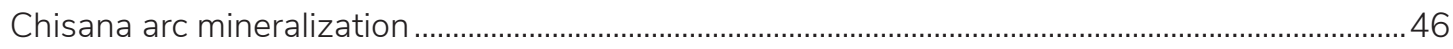

Cretaceous to Cenozoic arc-related mineralization .............................................................................46

Structurally controlled mineralization in the Talkeetna Mountains...................................................................4

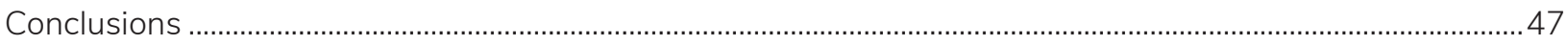

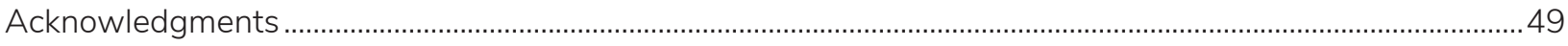

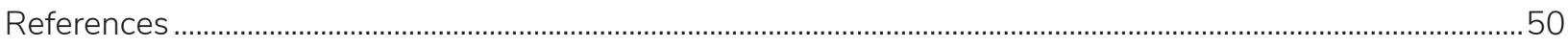

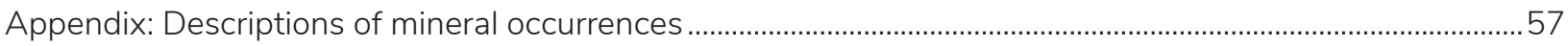

\section{Figures}

Figure 1. Map showing the distribution of the Wrangellia terrane, project area, and selected

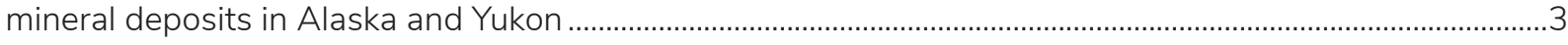

Figure 2. Map showing mineral occurrences discussed in this report .......................................................................

Figure 3. Bedrock geologic map of the eastern Denali Highway region .......................................................................

Figure 4. Geologic map of the Talkeetna Mountains C-4 Quadrangle …………………………………………..

Figure 5. Schematic stratigraphic columns from across the study area ................................................................

Figure 6. Photomicrographs illustrating the texture of Rainy Creek picrite ............................................................11

Figure 7. Hypabyssal picrite dike intrudes Rainy Creek dunite body and lithic fragments of dunite

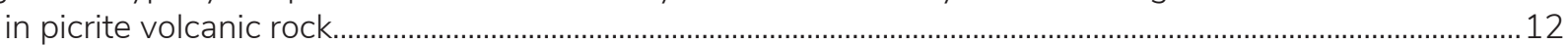

Figure 8. Geologic map of the Clearwater Creek and Pass Creek area .................................................................13 
Figure 9. Cross section through Wrangellia in the central Talkeetna Mountains 15

Figure 10. Simplified interpretive geologic map of the central Talkeetna Mountains .........................................17

Figure 11. Geologic map and cross section of the Amphitheater Mountains-Rainy Creek area......................20

Figure 12. Detailed geologic map of the central Alpha mafic-ultramafic intrusive complex at VABM Wild

Figure 13. Proposed structural assembly of the Amphitheater Mountains-Rainy Creek area .........................22

Figure 14. Simplified fault map showing the series of high angle normal faults south of the Talkeetna-Valdez Creek-Broxson Gulch fault system.

Figure 15. Map showing the distribution of whole-rock geochemical samples of Late Triassic mafic and ultramafic rocks generated for this project.

Figure 16. IUGS classification diagrams illustrating the major element compositions of noncumulate rocks

Figure 17. Selected major-element-oxide trends for non-cumulate rocks plotted against Mg \# $(100 *[\mathrm{molar} \mathrm{MgO} /(\mathrm{MgO}+\mathrm{FeO})]) ;$ vertical axes values given in percent

Figure 18. Bivariate scatterplot of $\mathrm{CaO}$ and $\mathrm{Cr}$ versus $\mathrm{MgO}$ for cumulate and non-cumulate samples .........27

Figure 19. Bivariate scatterplot of selected HFSE elements Zr, Y, and Th in non-cumulate samples ............27

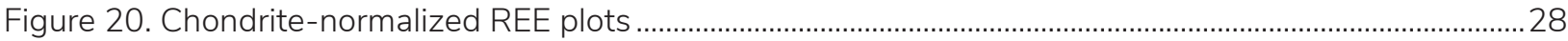

Figure 21. Bivariate scatterplots showing rare earth elements $\mathrm{Ce}$ versus $\mathrm{Yb}$, and $\mathrm{TiO}_{2}$ versus $\mathrm{Y}$ for

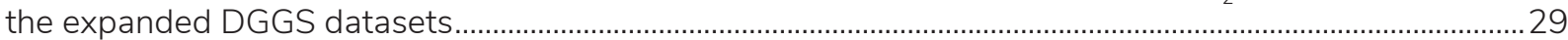

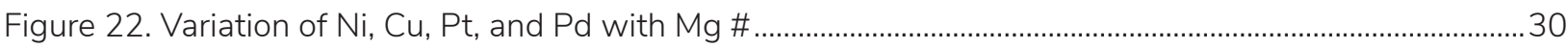

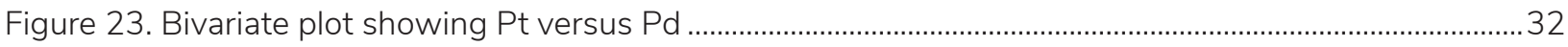

Figure 24. Bivariate plots of whole rock $\mathrm{Ni}$ versus $\mathrm{Cu}$, and whole rock $\mathrm{Ni}$ versus $\mathrm{S}$........................................33

Figure 25. Schematic diagram illustrating our understanding of the Late Triassic Nikolai Greenstone magmatic system and associated $\mathrm{Ni}$-Cu-Co-PGE mineralization and volcanic rocks .............35

Figure 26. Plot of $\mathrm{Pd}$ and Cu values (normalized to 100 percent sulfide) in comparison to typical magmatic sulfide compositions of different PGE-deposit types.........................................................................

Figure 27. Distribution of Late Triassic picrite volcanic rock samples from across the study area...................38

Figure 28. Distribution of Late Triassic mafic-ultramafic intrusions and high-Ti series olivine \pm

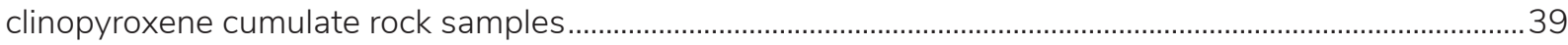

Figure 29. Samples depleted in Pt and Pd in the DGGS and BLM whole rock dataset....................................40

Figure 30. Map and bivariate plot showing the distribution of stream-sediment samples with greater than $10 \mathrm{ppb} \mathrm{Pt}$ or $\mathrm{Pd}$, and Pt/Pd ratio of 1 or greater or Pt/Pd ratio of less than 1 ....................... 41

Figure 31. Pt/Pd ratios and Pt values from rock samples, mafic-ultramafic intrusions, and major faults in the Rainy Creek and Amphitheater Mountains

Figure 32. Mobile-element (Sr, Ba) compositional data for samples of upper Nikolai Greenstone and average, unaltered basalt, $\mathrm{Ag} / \mathrm{Cu}$ ratios of mineralized samples by prospect and oremineral assemblage, $\mathrm{Zn} / \mathrm{Cd}$ ratios of mineralized samples by prospect, and $\mathrm{Ag} / \mathrm{Cu}$ versus $\mathrm{Au} /$ Cu ratios for copper-rich prospects in Wrangellia...

Figure 33. Photomicrographs (reflected light) showing replacement textures in sulfide mineralization........ 45

Figure 34. Energy dispersive spectroscopy images of chalcopyrite replacing framboidal pyrite in

Caribou Dome samples.

Figure 35. North-south cross section (no vertical exaggeration) through the Caribou Dome $\mathrm{Cu}-\mathrm{Ag}$ deposit showing the present-day setting of the deposit.

\section{Tables}

Table 1. Microprobe compositions of olivine from ultramafic samples across the study area ..........................31

Table 2. Pyroxene compositions from several ultramafic samples across the study area....... 


\section{Appendix}

Figure A1. Mineralization at site 1 (Unnamed — south tributary to Fog Creek) ....................................................58

Figure A2. Outcrop exposure of the quartz vein occurrence at site 2 (Unnamed —north of Peak 6910) ......59

Figure A3. Mineralization at site 5 (Unnamed_at Peak 6045) ..........................................................................61

Figure A4. Malachite-stained shear surfaces cutting metabasalt at site 6 (Unnamed—north of

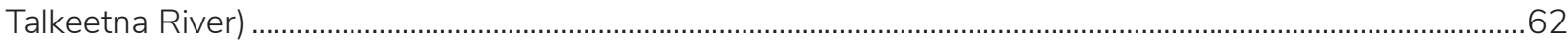

Figure A5. North-facing oblique view of part of the Red Ridge occurrence (site 7) .........................................64

Figure A6. Oblique aerial photo of the Butte Creek intrusive complex looking southeast.................................67

Figure A7. Schematic cross section of the Butte Creek intrusive complex at Peak 5532 ..............................68

Figure A8. Backscattered electron images of magmatic sulfide grains in sample 13RN423A .......................68

Figure A9. Enlargement of detailed geologic map at the Alpha ultramafic complex at the eastern end of the Eureka Zone ......................................................................................................................................

Figure A10. Photomicrographs of mineralization at the Eureka zone of the Alpha complex............................72 



\title{
MAGMATIC AND STRUCTURAL FRAMEWORK OF PGE AND OTHER MINERALIZATION IN NORTHWESTERN WRANGELLIA, CENTRAL ALASKA
}

Evan Twelker ${ }^{1}$, Lauren L. Lande ${ }^{1,2}$, Rainer J. Newberry², Alicja Wypych ${ }^{1}$, Karri R. Sicard ${ }^{1}$, and Lawrence K. Freeman ${ }^{1}$

\begin{abstract}
This report summarizes the findings of a multiyear Alaska Division of Geological \& Geophysical Surveys (DGGS) project to better understand the geologic context of mineralization hosted by the Wrangellia terrane in the eastern Alaska Range and Talkeetna Mountains, with particular emphasis on evaluating the area's potential for hosting the strategic and critical platinum-group elements (PGEs) and cobalt (Co). Subeconomic concentrations of these elements are already known to occur together with nickel $(\mathrm{Ni})$ and copper $(\mathrm{Cu})$ in magmatic-sulfide-type deposits. We take a mineral systems approach, our goal being to understand the ore-forming processes in order to assess the potential for undiscovered, economically extractable mineralization to occur in the study area.

Our work subdivides Wrangellia's Late Triassic mafic magmatism (known regionally as the Nikolai Greenstone and related intrusive rocks) into an early, low-titanium (Ti) series, a subsequent high-Ti series, and a primitive high-Ti series known as the Rainy Creek picrite. These distinctions apply to both extrusive and intrusive rocks. Known magmatic sulfide mineralization is strongly associated with cumulate ultramafic rocks and with primitive high-Ti melts such as those of the Rainy Creek picrite series. These magmas hybridized with those of the earlier, low-Ti series in multiphase sill complexes, inheriting cumulus minerals and also possibly magmatic sulfide. Our data show that sulfide saturation and depletion of chalcophile elements occurred locally, and that this saturation occurred prior to the fractionation of olivine. In these respects, the study area, particularly the Eureka Creek-Rainy Creek-Canwell Glacier area and the Butte Creek area, can be considered to be fertile and highly prospective for $\mathrm{Ni}$-Cu-Co-PGE sulfide deposits analogous to the Wellgreen deposit in Canada's Yukon. The more evolved magmas associated with the main, regionally extensive eruptive phase of the Nikolai Greenstone do not carry Ni-Cu-Co-PGE magmatic sulfide mineralization. These magmas evolved under sulfide-undersaturated conditions that caused enrichment of chalcophile elements, resulting in a copper-rich source rock for metamorphism-related copper deposits at Kennecott and Caribou Dome.

The rocks of the study area have been heavily modified by multiple generations of faults that crosscut the Triassic mineral systems; faults may localize some of the younger mineralization. In the central Talkeetna Mountains, thrust faults repeat and thicken the Wrangellia stratigraphic section; this apparently occurred during the Early Jurassic and prior to the complete accretion of Wrangellia to North America during the Cretaceous. Our work suggests that deformation related to the crustal-scale Talkeetna suture zone shifted southeastward after the Paleocene, moving from the Range Front fault to the Central Raingellia fault and nearby structures. In the Rainy Creek and Amphitheater Mountains areas, the Wrangellia stratigraphic section has been duplicated by large-scale, south-vergent thrust faulting. In the Clearwater and Amphitheater Mountains, a series of post-thrusting, west-northwest-striking, high-angle faults indicate a localized transtensional environment developed in response to regional, right-lateral tectonics.
\end{abstract}

${ }^{1}$ Alaska Division of Geological \& Geophysical Surveys, 3354 College Rd., Fairbanks, Alaska 99709-3707

${ }^{2}$ Department of Geosciences, University of Alaska, P.O. Box 755780, Fairbanks, Alaska 99775-5780 


\section{INTRODUCTION}

A thick and regionally extensive sequence of low-grade-metamorphosed Late Triassic basaltic rocks, the Nikolai Greenstone, is a characteristic component of the stratigraphy of the Wrangellia terrane in central and southeastern Alaska, Yukon, and British Columbia (fig. 1). Mafic to ultramafic intrusions feeding this extensive volcanic province hold high geologic potential for discovery of magmatic sulfide deposits containing nickel $(\mathrm{Ni})$, copper $(\mathrm{Cu})$, cobalt $(\mathrm{Co})$, the platinum-group elements (platinum $[\mathrm{Pt}]$, palladium $[\mathrm{Pd}]$, iridium [Ir], rhodium [Rh], osmium [Os], and ruthenium $[\mathrm{Ru}]$, collectively known as the PGEs), as well as gold $(\mathrm{Au})$ and silver $(\mathrm{Ag})$. In Yukon, exploration of these Late Triassic intrusions has led to the discovery of the Wellgreen (also known as Nickel Shäw) deposit, a preliminary economic-assessment-stage project with a measured and indicated resource of 6.0 million ounces combined Pt-Pd-Au, 2.1 billion pounds $\mathrm{Ni}, 1.1$ billion pounds $\mathrm{Cu}$, and 121 million pounds Co (Nickel Creek Platinum Corp., 2017). In our central Alaska study area, promising $\mathrm{Ni}-\mathrm{Cu}$ Co-PGE mineralization has been discovered at the Eureka zone and other early-stage prospects in the Paxson area.

Intrusive and extrusive products of these prospective Late Triassic magmas extend through central Alaska as a narrow belt in the eastern Alaska Range and the central Talkeetna Mountains (fig. 2); however, not all Nikolai Greenstone is the same, and there are important variations within this province that have bearing on its mineral potential. Recent work by Greene and others $(2008,2010)$ shows that the Late Triassic igneous rocks can be subdivided based on distinctive geochemical characteristics, suggesting new avenues for improvement of the region's geologic maps and $\mathrm{Ni}-\mathrm{Cu}-$ Co-PGE exploration models.

The Wrangellia terrane also holds high potential for other deposit types. High-grade epigenetic $\mathrm{Cu}-\mathrm{Ag}$ deposits at Kennecott, Alaska, with historic production of 1.18 billion pounds of copper and
9 million ounces of silver, are related to remobilization of metal from a copper-enriched subunit of the Nikolai Greenstone, which was then deposited into the overlying Chitistone Limestone during Jurassic to Cretaceous metamorphism associated with accretion of the Wrangellia terrane (MacKevett and others, 1997; Price, 2004). As discussed in this report, the Caribou Dome $\mathrm{Cu}-\mathrm{Ag}$ deposit (190,000 pounds Cu; Athey and Werdon, 2018), also known as Denali Copper, may share a similar genesis. Other mineral occurrences are related to magmatic arcs that developed in both pre-accretion settings on Wrangellia and post-accretion settings on the southern Alaska margin. Finally, fault activity and magmatism during the Paleogene localize a series of structurally controlled mineral occurrences in the central Talkeetna Mountains.

The location and timing of movement of the fault systems is of increased importance in the central Talkeetna Mountains due to the prospect of hydropower development along the Susitna River. Development of this resource will need to accurately account for hazards of both active and reservoir-induced seismicity.

In order to catalyze exploration success and resource development, the Alaska Division of Geological \& Geophysical Surveys (DGGS) undertook a multiyear, multidisciplinary effort to improve public-domain geologic data, with dual emphasis on Late Triassic mafic-ultramafic magmatism and the location and history of fault systems in the region. We sought to improve geologic mapping of high-mineral-potential areas with a combination of new targeted geologic mapping, airborne geophysical surveys, and compilation and reinterpretation of published and unpublished maps. We used geochemistry, petrography, and geochronology to more precisely understand the magmatic context of $\mathrm{Ni}-\mathrm{Cu}-\mathrm{Co}-\mathrm{PGE}$ mineralization, and this context has been used to better evaluate mineral potential within the study area. Finally, we have generated a large dataset of modern rock, stream sediment, and pan concentrate geochemical analyses to directly evaluate individual drainages for the presence of mineralization. 


\section{Overview of DGGS Wrangellia Project}

This report summarizes fieldwork conducted by DGGS geologists during the 2013 through 2015 field seasons. During the initial 2013 field season, mineral resources geologists from DGGS carried out a 19-day, helicopter-supported geological and geochemical resource assessment and gravity survey in parts of the Gulkana, Healy, Mount Hayes, and Talkeetna Mountains quadrangles. Publications include whole rock and exploration (stream sediment, pan concentrate, and rock)

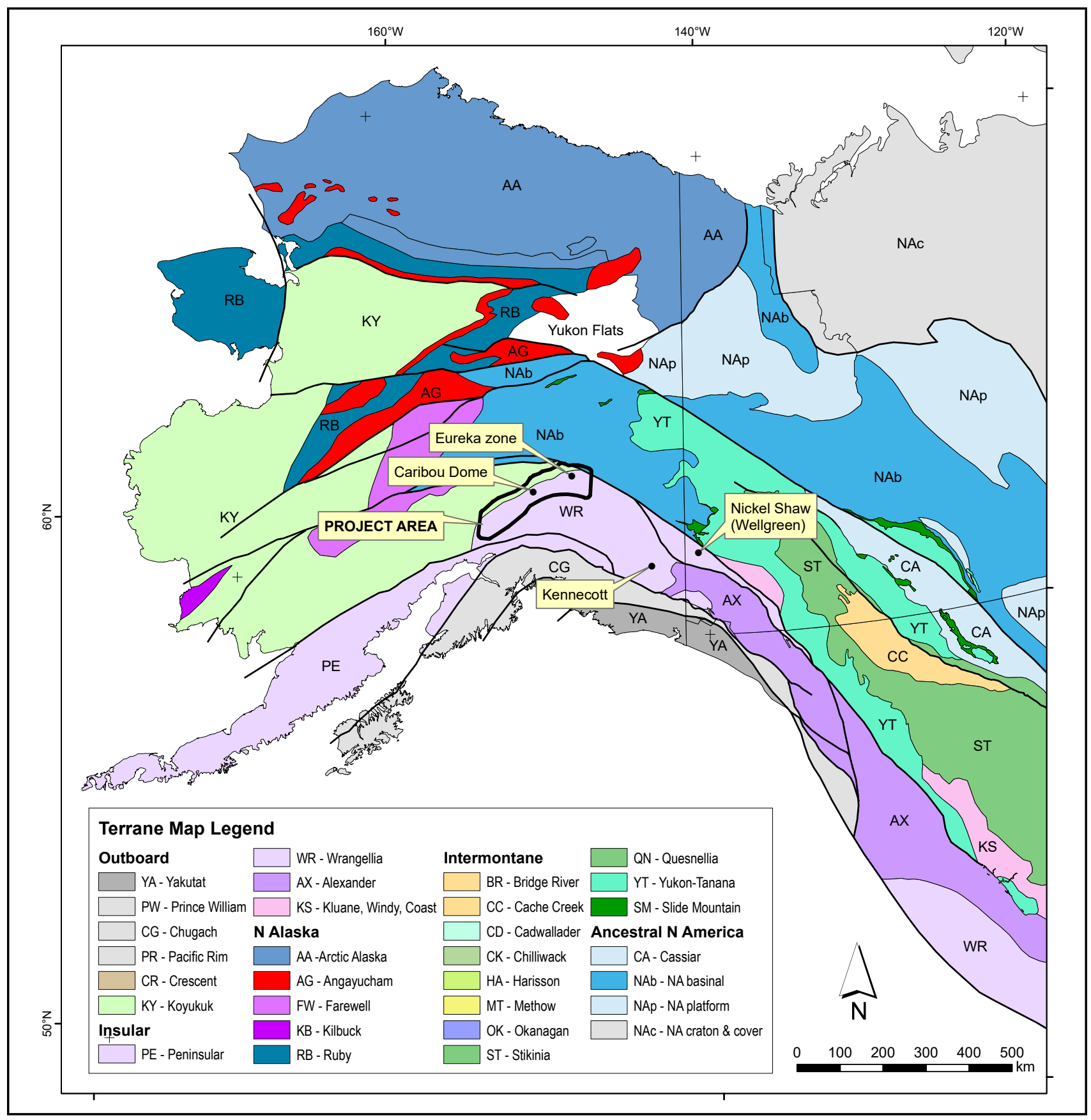

Figure 1. Map showing the distribution of the Wrangellia terrane, project area, and selected mineral deposits in Alaska and Yukon (modified from Colpron and Nelson, 2011). 


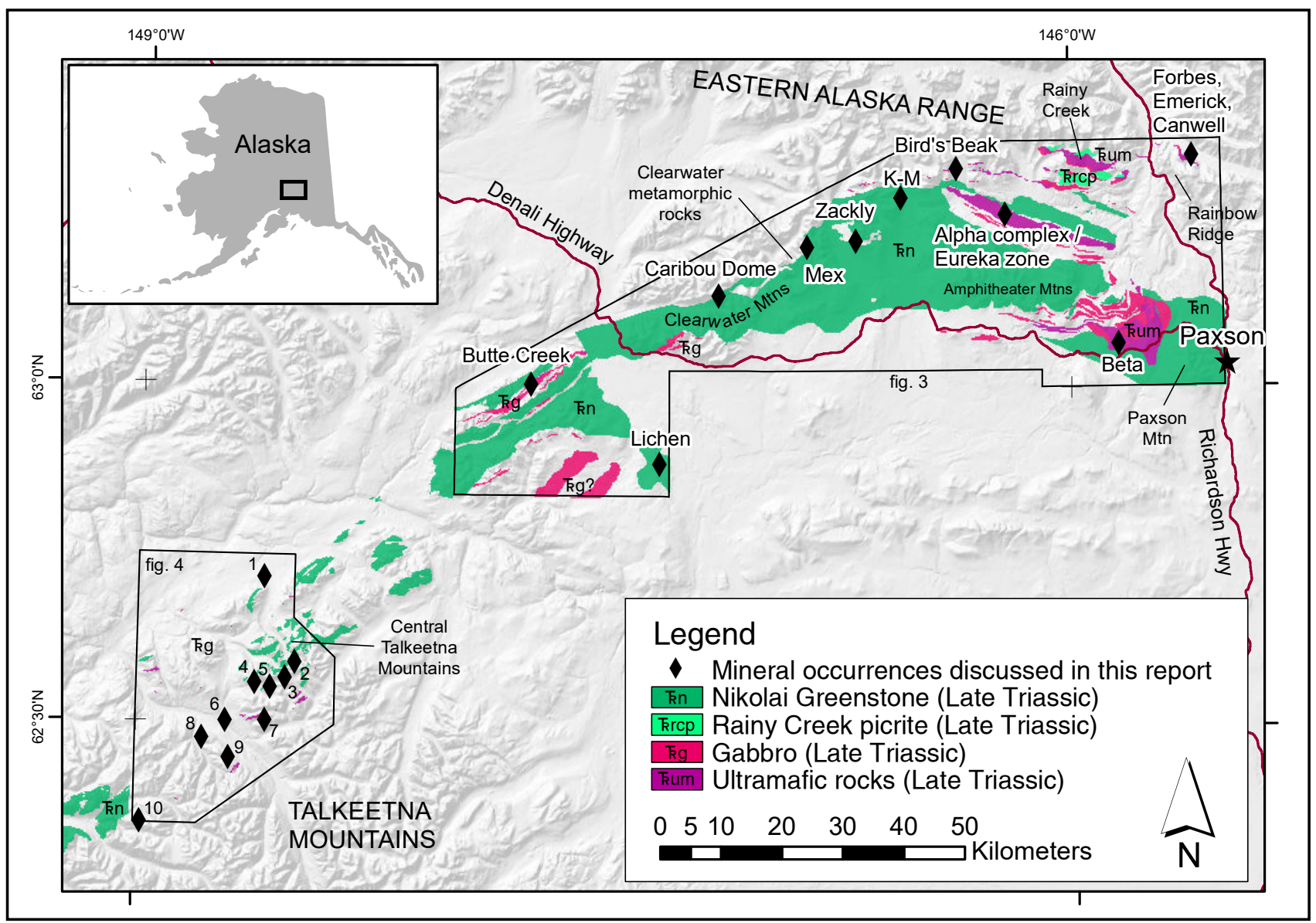

Figure 2. Map showing mineral occurrences discussed in this report and the distribution of Late Triassic Nikolai Greenstone and genetically related intrusive igneous rocks in the study area. Geology adapted from DGGS and DGGS-supported mapping (Werdon and others, 2002; Twelker and others, 2015a; Lande, 2016; Twelker and others, 2020) and USGS mapping published by Greene and others (2010) and Nokleberg and others (2015).

geochemical datasets (Twelker and others, 2014) and six ${ }^{40} \mathrm{Ar} /{ }^{39} \mathrm{Ar}$ ages (Benowitz and others, 2014).

In partnership with the U.S. Geological Survey (USGS), DGGS funded re-analyses of 1,682 historical USGS sediment samples listed in the statewide Alaska Geochemical Database Version 2.0 (AGDB2; Granitto and others, 2013). Samples were chosen from an area covering the western half of the Wrangellia terrane in the Anchorage, Gulkana, Healy, Mt. Hayes, Nabesna, and Talkeetna Mountains quadrangles of south-central Alaska (Werdon and others, 2014).

DGGS contracted CGG and Fugro Geosciences to fly the 3,500-sq-km Wrangellia airborne magnetic and electromagnetic survey using the helicopter-borne DIGHEM frequency domain system at a 400- $\mathrm{m}$ line spacing and $30-\mathrm{m}(100-\mathrm{ft})$ ground clearance (Burns and others, 2014a). This survey covers the Butte Creek, Windy Creek, and parts of the Maclaren River drainages, and connects other surveys covering adjacent parts of the Wrangellia terrane, including the Iron Creek (Burns and others, 2014b), Valdez Creek (Burns and others, 2004), and Southern Delta River surveys (Burns and others, 2003).

DGGS, in consultation with its Geologic Mapping Advisory Board, identified an area of the central Talkeetna Mountains with geologic potential for $\mathrm{Ni}-\mathrm{Cu}-\mathrm{Co}-\mathrm{PGE}$ mineralization and only reconnaissance-scale geologic maps. To fill this gap in geologic map coverage, DGGS conducted a 42-day, 1,165 -sq-km mapping project in the Talkeetna Mountains C-4 Quadrangle and adjoining areas 
during the 2014 field season. Resulting publications include a preliminary geologic map (Twelker and others, 2015a), and supporting geochemical data (Wypych and others, 2014) and ${ }^{40} \mathrm{Ar} /{ }^{39} \mathrm{Ar}$ geochronology (Benowitz and others, 2015).

In 2015, DGGS geologists completed an additional 10 days of targeted mapping and sampling in the Butte Creek, Windy Creek, and Eureka Creek areas. This campaign targeted unresolved geologic relationships in the northeastern Talkeetna Mountains, Clearwater Mountains, and the Eureka Creek area, with special emphasis on tracing suspected, unmapped Late Triassic mafic and ultramafic intrusions and volcanic rocks indicated in previous reports and geophysical surveys. Wypych and others (2015) published the geochemical results from this work.

In an effort to resolve controversy about the geologic origins of the Alpha ultramafic complex (also known as the Fish Lake complex), DGGS and the University of Alaska Fairbanks jointly sponsored the Master of Science thesis of Lauren Lande (Lande, 2016), a detailed examination of the petrology, contact relationships, and trends in mineral compositions across the complex.

DGGS also worked in cooperation with Trevor Waldien, a PhD candidate at the University of California, Davis, who in 2015 began mapping and research on the Broxson Gulch and Valdez Creek fault systems bounding the northern edge of Wrangellia.

\section{Geological dataset}

This report summarizes geological mapping and sampling conducted by DGGS during the 2013 through 2015 field seasons, plus compilation, synthesis, and reinterpretation of existing geologic maps in light of recently flown geophysical surveys. This reinterpreted geology is illustrated by DGGS Report of Investigations 2020-7 (fig. 3; Twelker and others, 2020), while a stand-alone map of the central Talkeetna Mountains was published as Preliminary Interpretive Report 2015-6 (fig. 4; Twelker and others, 2015a).

\section{Geochemical dataset and methods}

This report references whole rock geochemical data published by DGGS (Twelker and others, 2014; Wypych and others, 2014; 2015). DGGS field geologists sampled outcrops, trimmed weathered surfaces, and submitted the samples to ALS Minerals for crushing, pulverization, and analysis. Major and minor oxides were analyzed by lithium metaborate fusion digestion and ICP-AES. Trace elements, including rare earth elements, were determined using lithium metaborate fusion digestion and ICP-MS. Ag, Cd, Co, Cu, Li, Mo, Ni, Pb, Sc, and $\mathrm{Zn}$ were determined by four-acid digestion and ICP-AES; and As, Bi, Hg, In, Re, Sb, Se, Te, and $\mathrm{Tl}$ were determined by aqua regia digestion followed by ICP-MS. Total C and S were analyzed by LECO furnace. Platinum, palladium, and gold values were analyzed by 30 -g fire assay with ICP-MS finish. We calculated $\mathrm{FeO}$ and $\mathrm{Fe}_{2} \mathrm{O}_{3}$ from reported total $\mathrm{Fe}_{2} \mathrm{O}_{3}$ according to the method of Le Maitre (1976), normalizing major elements to 100 percent on a volatile-free basis using IgPet software (Carr and Gazel, 2017). We also used whole rock data for Ni-Cu-Co-PGE-mineralized samples collected by the U.S. Bureau of Land Management (Bittenbender and others, 2007).

\section{PENNSYLVANIAN TO TRIASSIC STRATIGRAPHY OF WRANGELLIA}

Our mapping and reinterpretation indicate some basic consistencies as well as differences in the generalized stratigraphy of Wrangellia across the study area (fig. 5).

The base of the section, where exposed, consistently comprises volcanic flows, breccias, and volcaniclastic rocks (unit Pmv; fig. 5) of mafic to intermediate composition (andesite, basalt, and, locally, dacite). The base of this unit is not exposed, and the unit has a minimum thickness of several kilometers. The mafic to intermediate volcanics are overlain by felsic (dacite to rhyolite) volcaniclastic rocks with lesser felsic flows and interbedded sedimentary rocks $(\mathbb{P f v})$. This unit ranges in thickness 


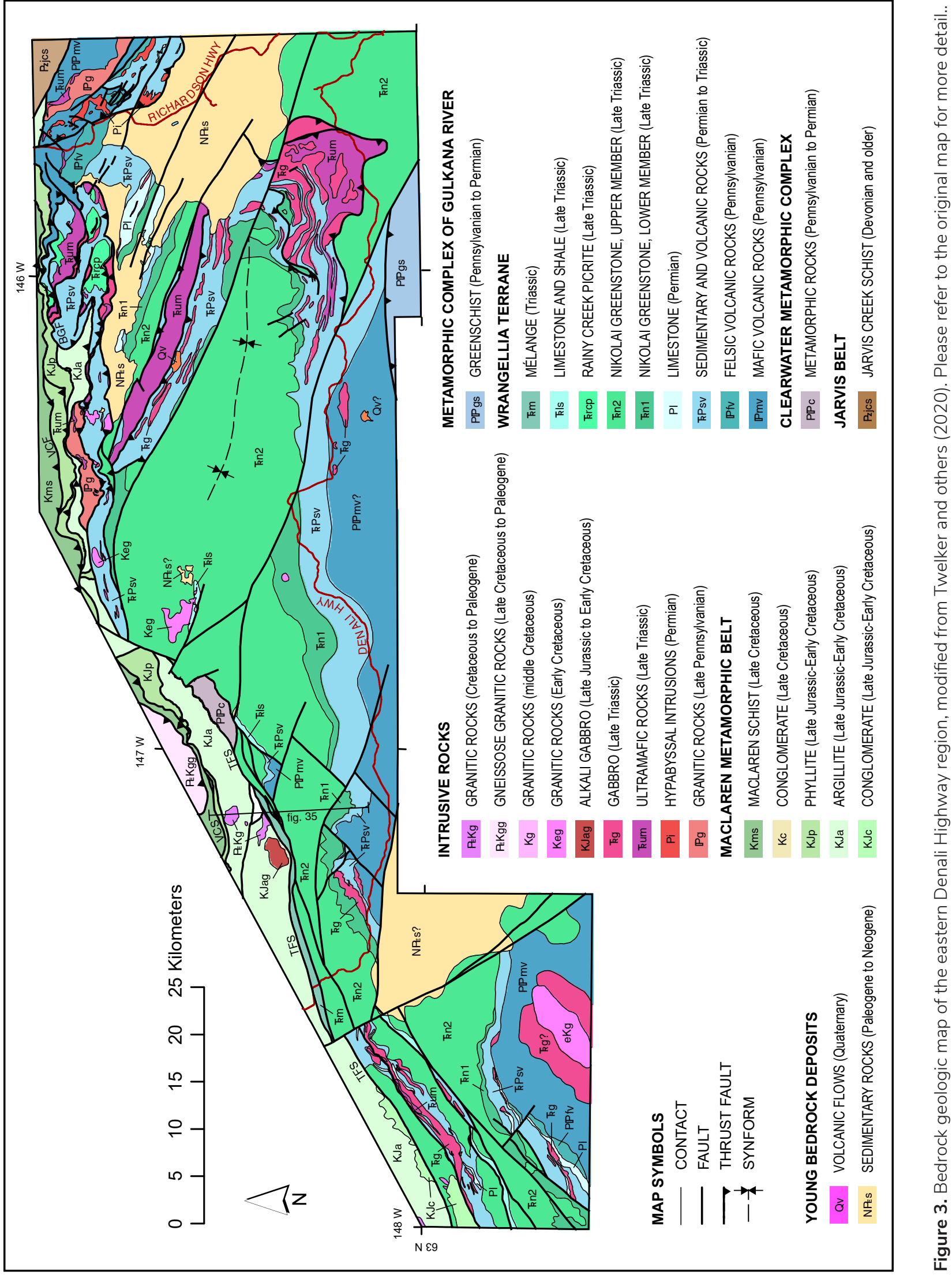




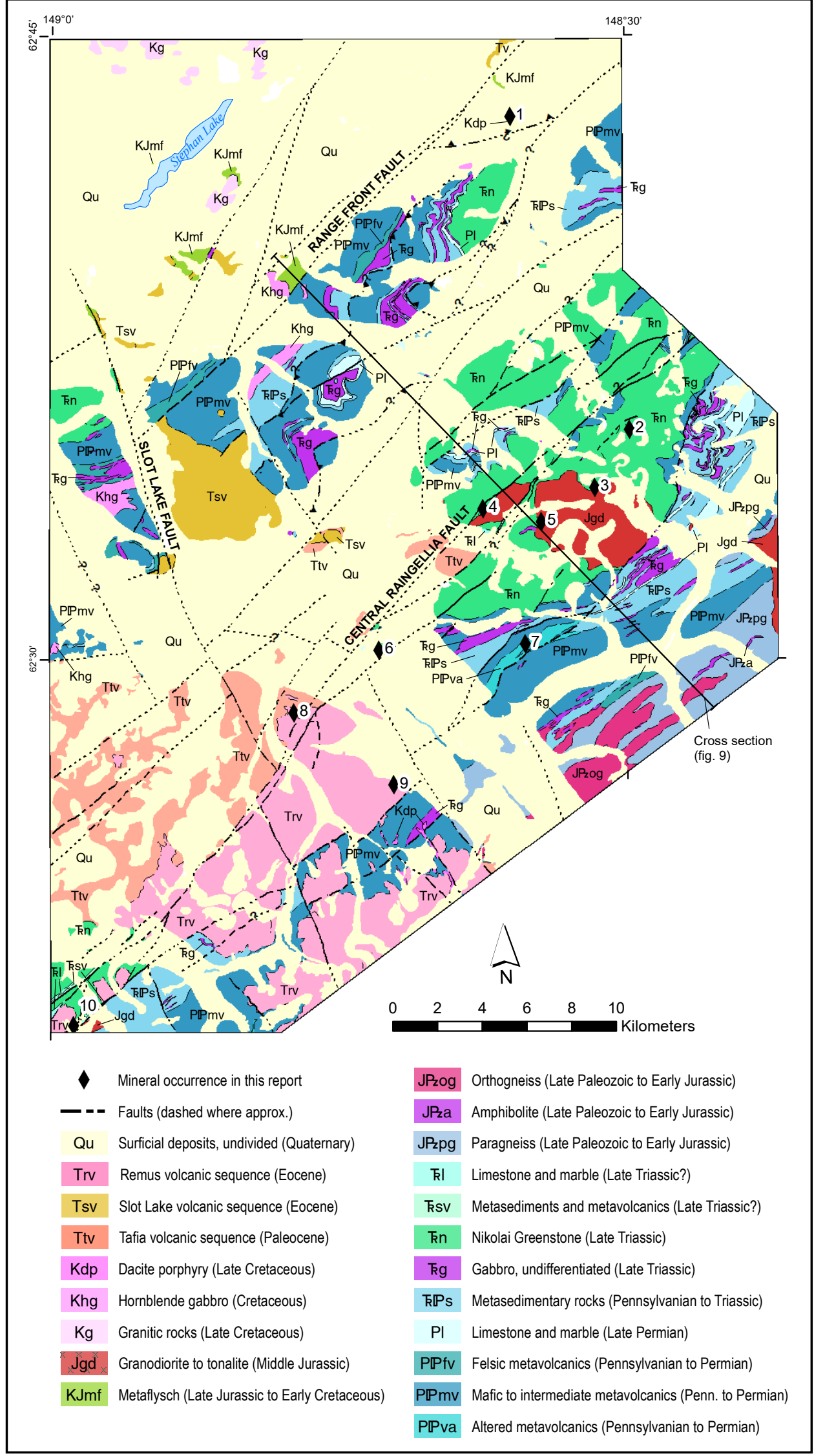

Figure 4. Geologic map of the Talkeetna Mountains C-4 Quadrangle, modified from Twelker and others (2015a); please refer to the original map for more detail. Numbered diamonds refer to mineral occurrences described in the appendix to this report. 
from 0 to $500 \mathrm{~m}$; it appears to be discontinuous in the central Talkeetna Mountains (Twelker and others, 2015a), thickest in the Rainbow Ridge area (fig. 2), and absent in the Clearwater Mountains. Together, these rocks comprise the extrusive portion of the Skolai intra-oceanic volcanic arc. Granitic rocks of Pennsylvanian age, unit $\mathbb{P g}$, comprise the plutonic roots of this arc.

A mixed unit of interlayered sedimentary and volcanic rocks (unit kPsv) forms a regionally continuous stratigraphic horizon. The estimated thickness of this unit is 500 to more than 2,000 $\mathrm{m}$. This unit is time-equivalent to the Hazen Creek and Eagle Creek formations (Wilson and others, 2015). Fossil and radiometric ages from this unit are predominantly Early to Middle Permian, leaving space for a greater-than-25-Ma unconformity prior to the deposition of the Nikolai Greenstone in the
Late Triassic. However, two microfossil localities in the Clearwater Mountains (Silberling and others, 1981) indicate that a portion of these sedimentary rocks are Early Triassic in age and may be conformably overlain by the Nikolai Greenstone. We tentatively interpret the isolated presence of Early Triassic sediments as reflecting paleoenvironment; however, this pattern could also be an artifact of the limited microfossil dataset for the area.

Beds of mostly Early Permian limestone (PI) occur within the sedimentary and volcanic rock package (KPsv), but their abundance varies across the study area. The Paxson Mountain-Delta River area, mapped as Eagle Creek Formation by previous workers (Nokleberg and others, 2015), has the highest abundance of limestone beds.

Late Triassic gabbros $(\mathrm{kg})$ and cumulate ultramafic bodies (Rum) intrude mostly as sills

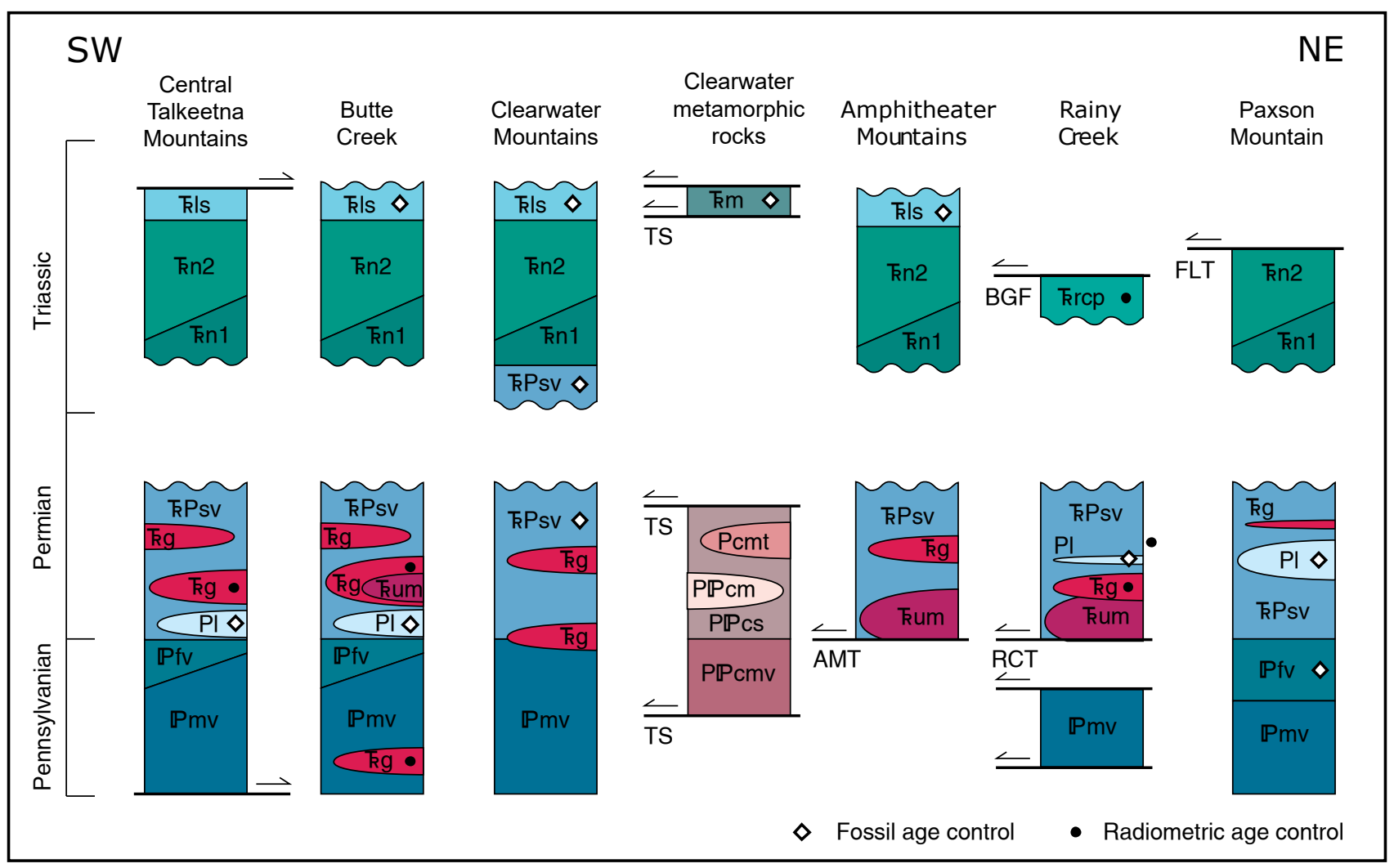

Figure 5. Schematic stratigraphic columns from across the study area. Refer to figure 2 for schematic section locations and figure 3 for map unit abbreviations. Named fault systems: TS-Talkeetna shear zone; FLT-Fish Lake thrust; RCT-Rainy Creek thrust; BGF-Broxson Gulch fault. See geologic maps (Twelker and others, 2015a; Twelker and others, 2020) for summaries of radiometric and fossil age data. 
within the Permian to Triassic sedimentary and volcanic rock package (KPsv). Exceptions include intrusions into Permian granitic rocks $(\mathbb{P g})$ in the Canwell Glacier and Eureka Glacier areas. The intrusions are most abundant in the Amphitheater Mountains, Rainy Creek, and Butte Creek areas, and least abundant in the Paxson Mountain-Delta River area (fig. 5). Mappable volumes of ultramafic rock were found to occur only in the Butte Creek, Amphitheater Mountains, Rainy Creek, and Canwell Glacier areas.

Variants of the Nikolai Greenstone occur throughout the study area. As discussed later in this report, we divide the Nikolai Greenstone into high- and low-Ti members following the criteria of Greene and others (2008). The low-Ti member ( $\mathrm{kn} 1)$ is discontinuously present in all areas of the study area except the Rainy Creek area; however, dunite in the Rainy Creek area may represent a conduit that fed low-Ti volcanic rocks that were subsequently eroded. Approximate interpreted stratigraphic thicknesses of this unit range from 0 to $800 \mathrm{~m}$, with the greatest thickness occurring in the Clearwater Mountains area. This is a chemically defined unit that is similar to, but not the same as, the stratigraphically lower, pillowed Nikolai Greenstone variant mapped by previous workers (Stout, 1976; Silberling and others, 1981).

Similarly, the high-Ti Nikolai Greenstone member $(\mathrm{kn} 2)$ is distributed throughout the study area but not found in the Rainy Creek area. Total estimated thickness may reach as much as $4,000 \mathrm{~m}$ where the overlying stratigraphy is preserved. This unit lacks pillow structures and is generally interpreted to have been erupted subaerially (Greene and others, 2010).

Volcanic rocks of picrite (high-magnesium $[\mathrm{Mg}]$ basalt) composition (unit Krcp) were recognized in the Rainy Creek area by Rose (1966), Hulbert and Stone (2006), and Greene and others (2008); as discussed later in this report, the Rainy Creek picrites are closely similar to the high-Ti Nikolai Greenstone $(\mathrm{kn} 2)$ in terms of trace element geochemistry. Structural complexity hinders the estimation of unit thickness, but one exposure in the western fork of Rainy Creek suggests a thickness of more than 1,000 m. A sample of the Rainy Creek picrite (Bittenbender and others, 2007) yielded an ${ }^{40} \mathrm{Ar} /{ }^{39} \mathrm{Ar}$ hornblende cooling age of $225.7 \pm 2 \mathrm{Ma}$ that the authors interpret as the age of volcanism; this age is consistent with that of Nikolai Greenstone magmatism regionally (Greene and others, 2010). Evidence presented in this report supports our interpretation that the Rainy Creek picrite and the high-Ti series magmas evolved along separate paths from a common melt.

The Wrangellia section is capped by a Late Triassic limestone and shale unit ( $\mathrm{k} / \mathrm{s})$ that is only locally preserved in the study area.

\section{Rainy Creek picrite}

We address the Rainy Creek picrites separately in this report because they are a unique lithology that is, as discussed in a later section, potentially important to the formation of $\mathrm{Ni}-\mathrm{Cu}-\mathrm{Co}-\mathrm{PGE}$ mineralization in the study area. While the picrite unit was recognized by Rose (1966), Greene and others (2008), and by industry working in the area, it has been combined with other volcanic units in the prevailing geological compilations (Stout, 1976; Nokleberg and others, 1992, 2015). The petrological and economic significance of this unit hinges on whether the high-Mg composition is a primary property of the melt or the result of accumulation of olivine. This section presents our observations regarding the texture and contact relationships of this unit, which indicate that the Rainy Creek picrite represents a high-Mg initial melt.

The picrite unit, aside from scattered hypabyssal dikes, is clearly volcanic in texture and is characterized by aphanitic, often fragmental textures with few phenocrysts of any kind. Photomicrographs of picrite samples are shown in figure 6. Some samples are partially recrystallized to a Mg-rich, low-grade metamorphic assemblage of actinolite and chlorite. 
The aphanitic volcanic textures and lack of olivine phenocrysts indicate that the Rainy Creek picrites originated as a high-Mg melt, rather than a normal basaltic melt that gained $\mathrm{Mg}$ through cumulate processes. Calculations based on major-element compositions indicate that the approximate bulk composition of the Rainy Creek picrite could be formed through the addition of about 25 to 30 percent cumulate olivine to the "normal" basaltic melt composition represented by the high-Ti member of the Nikolai Greenstone. As petrography shows (fig. 6), phenocryst olivine is a trace phase and not present in anywhere near the abundance that would suggest a "normal" but olivine-contaminated basalt.

Field relationships indicate that hypabyssal dikes of Rainy Creek picrite intrude the Rainy Creek dunite body (fig. 7A), and lithic fragments of dunite occur in picrite volcanic rocks in several locations in the area (fig. 7B). In addition to intrusive relationships, mapping in the Rainy Creek area suggests picrite volcanics were emplaced onto both Permian to Triassic sedimentary and volcanic rocks (KPsv) and the earliest of the dunite sills intruding these strata (Kum; Twelker and others, 2020). Further, the low-Ti series Nikolai Greenstone is missing from the volcanic section in this area, even though its intrusive equivalents occur in the area (fig. 5).

The above observations suggest the existence of a short-lived angular unconformity beneath the Rainy Creek picrite. Geochronology and regional relationships indicate that both the Rainy Creek picrite and the dunite body in that area were emplaced during the short-lived but voluminous Late Triassic magmatic episode, which lasted as little as 2 million years (Greene and others, 2010). We interpret the dunite complex in the Rainy Creek area to be part of the earlier, low-Ti magma series of Nikolai magmas based on its relatively high calculated melt $\mathrm{Mg}$ \# and relatively low calculated melt $\mathrm{TiO}_{2}$ content based on olivine analyses (table 1). Therefore, the observed crosscutting relationships are consistent with the relative ages of the Rainy Creek and low-Ti series magmas. The apparent angular unconformity is also consistent with the relative ages, but implies rapid crystallization, exhumation, and erosion during the presumably brief interlude between the low-Ti and Rainy Creek phases of magmatism. This is in stark contrast to the Alpha (Fish Lake) ultramafic complex, where Lande (2016) documents evidence of mixing and hybridization of low- and high-Ti series magmas in shared magma chambers. In summary, the Rainy Creek area seems to represent a very dynamic geological environment where (1) highly unusual picrite melts, the Rainy Creek picrite, were able to reach the surface and (2) significant uplift and erosion occurred during the Nikolai magmatic event. Both of these features are apparently unique within the context of the Late Triassic Nikolai Greenstone in Alaska and Yukon (e.g., Greene and others, 2010).

\section{Clearwater metamorphic rocks}

The Clearwater metamorphic rocks, or Clearwater terrane of Jones and others (1987), comprise a fault-bound, 15-sq-km block of greenschist-facies schistose to gneissic metasedimentary and metaigneous rocks in the upper Clearwater Creek drainage (fig. 8). These rocks lie along the Talkeetna shear zone between Jurassic-Cretaceous argillite (unit KJa of Twelker and others, 2020) and the Nikolai Greenstone (unit kn2). Previous work (Silberling and others, 1981; Jones and others, 1987) defined the Clearwater terrane to include rocks in both the Clearwater Creek and Windy Creek drainages. Rocks in the Windy Creek drainage (fig. 8; unit $\mathrm{km}$ of Twelker and others, 2020) contain the Late Triassic fossil Heterastridium (Silberling and others, 1981), while rocks in the Clearwater Creek drainage contain conodonts assigned a "preliminary" age of Silurian(?) to Devonian(?), plus conodont fragments and ichthyoliths suggesting an age range of Late Devonian to Triassic (Clautice and others, 1989). Pre-Pennsylvanian ages are inconsistent with the Wrangellia terrane (as currently understood) and would require long-distance tectonic transport. 

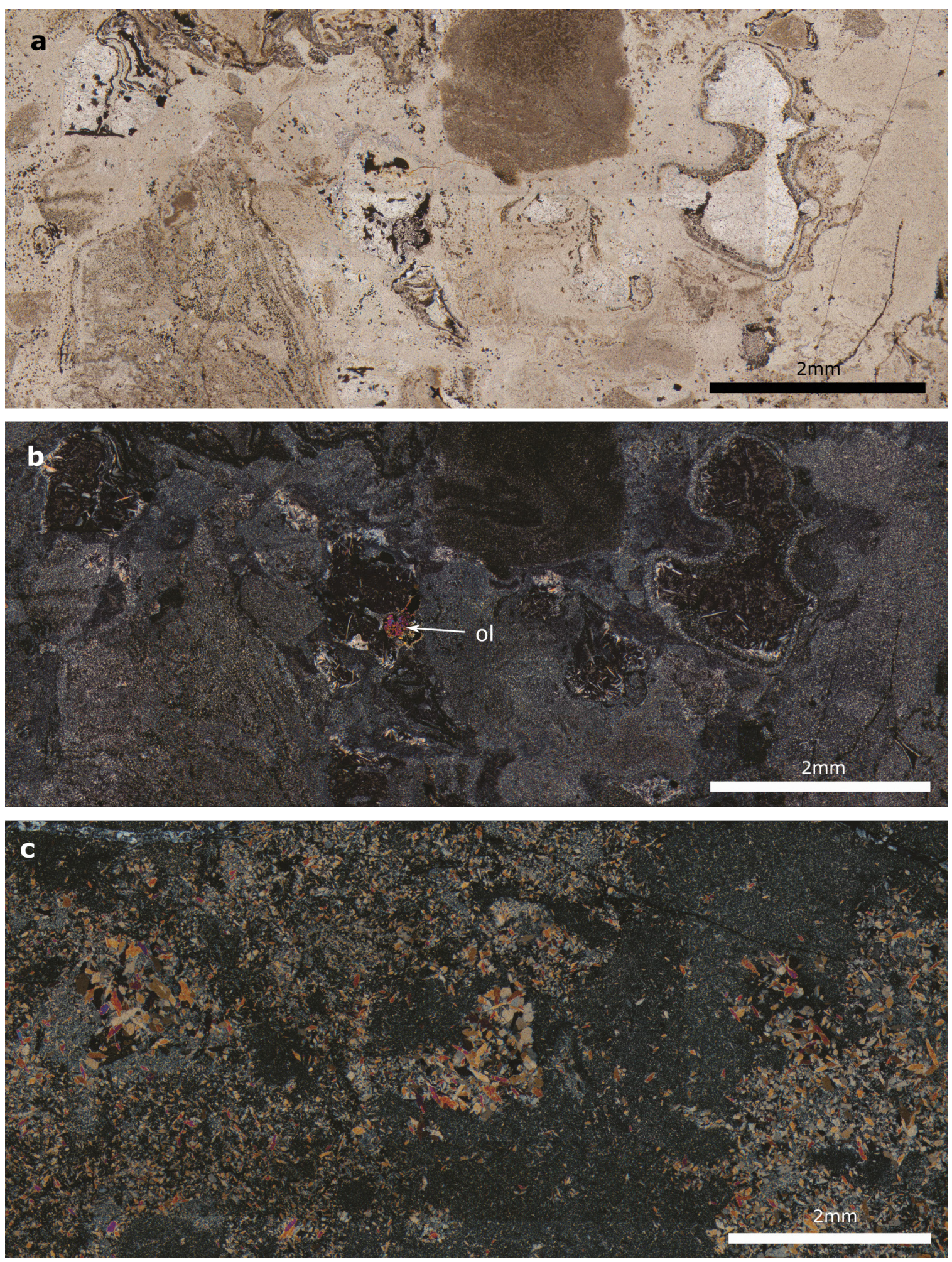

Figure 6. Photomicrographs illustrating the texture of Rainy Creek picrite. The aphanitic, fragmental, and nearly phenocryst-free texture of this volcanic rock is shown in plane polarized light (A) and cross-polarized light. B. The high birefringence grain at center is an olivine phenocryst (ol). C. Partial replacement of volcanic groundmass by actinolite. 

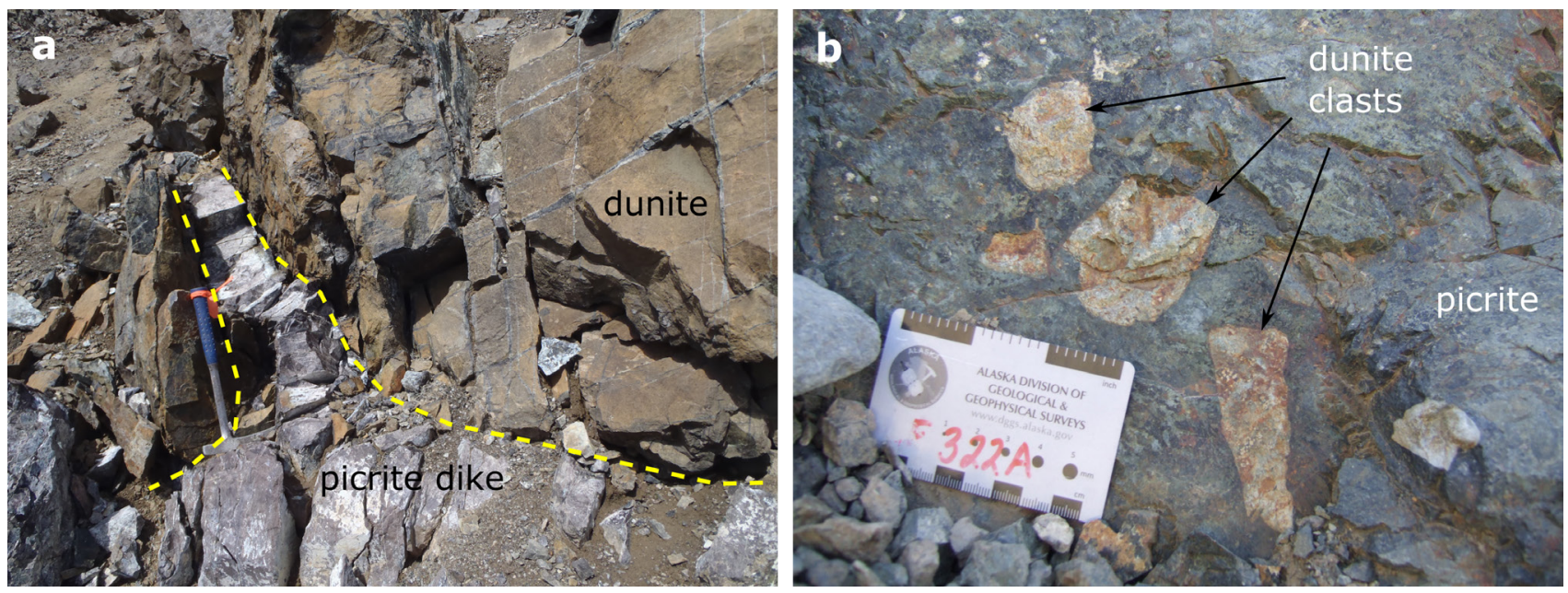

Figure 7. A. Hypabyssal picrite dike intrudes Rainy Creek dunite body. B. Lithic fragments of dunite in picrite volcanic rock.

DGGS obtained two U-Pb zircon ages from Clearwater metaigneous rocks (fig. 8); both yielded Early to Middle Permian ages. Zircons from a stratigraphically conformable unit of mixed metatuff and metasedimentary rocks (unit Pcmt of Twelker and others, 2020) give an age of $277.3 \pm 11.8 \mathrm{Ma}$, and a crosscutting body of medium- to coarse-grained granitic orthogneiss (unit Pcog of Twelker and others, 2020) yielded a magmatic crystallization age of $268.1 \pm 11.6 \mathrm{Ma}$ (13 zircons). A subordinate population of grains (nine zircons) have older ages ranging from 285 to $308 \mathrm{Ma}$; no grains had ages older than $308 \mathrm{Ma}$ (Twelker and O'Sullivan, 2016).

Early to Middle Permian magmatic ages are consistent with the fossil ages of similarly interlayered sedimentary and volcanic rocks and limestone of the upper Slana Spur Formation (Nokleberg and others, 1992; unit KPsv of Twelker and others, 2020). The Clearwater orthogneiss may be temporally equivalent to the Early to Middle Permian hypabyssal intrusions in the Rainbow Ridge area (unit Pi of Twelker and others, 2020), which intrude rocks containing Early Permian fossils. The older zircon population (285-308 Ma) from the Clearwater orthogneiss sample may reflect inheritance from the main stage of the Skolai arc (290-320 Ma; Beard and Barker, 1989). Such inheritance, as well as the lack of any Precambrian inheritance, provides evidence that the Clearwater terrane is a metamor- phosed fragment of the upper Paleozoic stratigraphy of Wrangellia, rather than a fault-bound sliver of far-traveled metamorphic rock such as the Permian Klondike assemblage documented north of the Denali fault (Jones and others, 2017).

Geologic interpretation based on aeromagnetic data by DGGS (fig. 8; Twelker and others, 2020) indicates that the Windy Creek (unit Km) and Clearwater Creek (units Pcmt, PPcm, etc.) components of Jones and others' (1987) Clearwater terrane do not connect through the low-lying area of Pass Creek. However, both apparently share a similar origin as components of Wrangellia stratigraphy that have been modified by proximity to the Talkeetna shear zone.

\section{STRUCTURAL GEOLOGY}

In central Alaska, Wrangellia comprises a relatively narrow belt of low-grade metamorphic rocks surrounded by fault systems active from the Early Jurassic and continuing through to the present. The volcanic, intrusive, and sedimentary rocks of Wrangellia formed in a dynamic but poorly understood tectonic environment, and they subsequently experienced prehnite-pumpellyite to lower greenschist facies regional metamorphism during the Early to Middle Jurassic (Dusel-Bacon, 1994). To the south, amphibolite facies rocks correlated to the Strelna metamorphic complex also experienced 


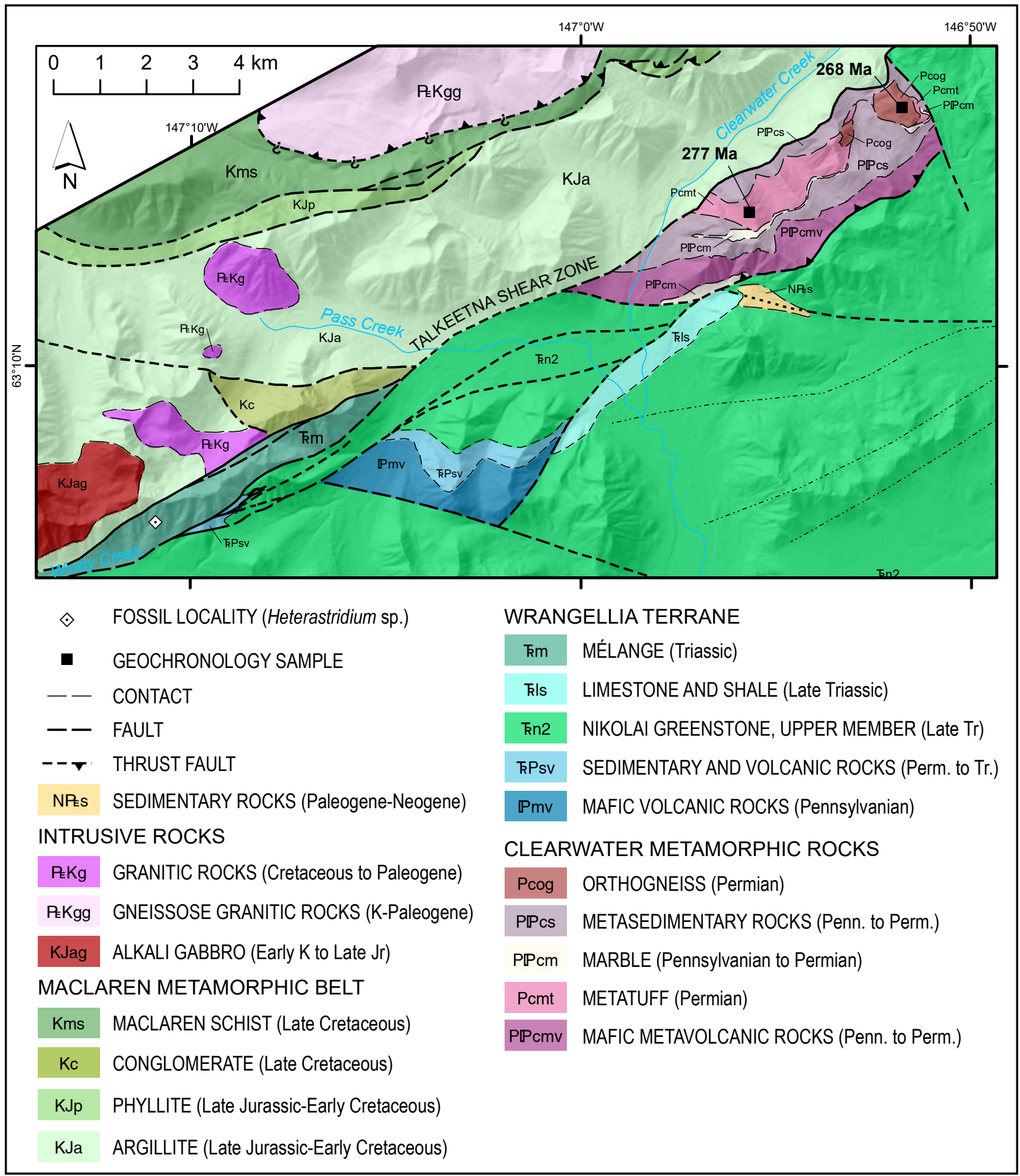

Figure 8. Geologic map of the Clearwater Creek and Pass Creek area, excerpted from Twelker and others (2020). 
metamorphism during this Early to Middle Jurassic timeframe. Along its northern margin, Wrangellia is separated from Jurassic through Cretaceous metasedimentary rocks by faults related to the crustal scale Talkeetna suture zone, a long-lived and deep-seated structure expressed at surface as faults including the Broxson Gulch fault, the Talkeetna fault, the Range Front fault, and the Central Raingellia fault (figs. 2, 4). Younger rocks to the north of Wrangellia experienced variable, sub-greenschist to amphibolite facies metamorphism during Late Cretaceous to Paleogene time (Davidson and McPhillips, 2007). Neogene tectonics of the area are dominated by shortening and exhumation of the eastern Alaska Range, plus continued activity along faults of the Talkeetna suture zone.

A full treatment of this structurally complex region is beyond the scope of this report. The following section will focus on our observations from three seasons of fieldwork, with emphasis on the geology as it relates to potential resource development in the study area.

\section{Late Triassic structural history}

The oldest elements of the region's structural history considered by this report are those that could hypothetically control the emplacement of Late Triassic mafic magmas and their associated $\mathrm{Ni}-\mathrm{Cu}-\mathrm{Co}-\mathrm{PGE}$ sulfide mineralization. The locations and geometry of high-throughput magma conduits or feeders (in this study, Late Triassic gabbros and ultramafic rocks) are important aspects of the ore-forming process at Norilsk and similar $\mathrm{Ni}-\mathrm{Cu}-\mathrm{Co}-\mathrm{PGE}$ deposits worldwide (Barnes and Lightfoot, 2005).

As discussed in the previous section, the generation, transport, and eruption of picrite melts at the surface and the development of a short-lived unconformity within the timeframe of Late Triassic Nikolai Greenstone magmatism represent a unique and very dynamic geologic environment. This environment could be driven by either structural forces, such as rifting (Nokleberg and others, 1985), or by magmatic forces, such as the arrival of a mantle plume (Greene and others, 2010). Resolution of this question is beyond the scope of this report.

Field observations by DGGS indicate that most of the mafic to ultramafic intrusions are sill-form and emplaced into Permian to Triassic metasedimentary and metavolcanic strata (unit kPsv). We infer a relatively shallow depth of emplacement (less than $2 \mathrm{~km}$ ) based on the sill-form geometry, the fine grain size, and because the host strata are bounded above by an Early Triassic unconformity.

Mafic to ultramafic intrusions in the Canwell Glacier and Eureka Glacier areas must have been emplaced at a deeper crustal level because they intrude granitic rocks that represent the intrusive roots of the Pennsylvanian Skolai volcanic arc (unit $\mathbb{P g}$ ). These granitic rocks are structurally bound by Cenozoic thrust faults, and the original geometry of the ultramafic intrusions is unknown; however, they may be deeper-level feeders to the ultramafic and volcanic rocks at higher stratigraphic levels. $\mathrm{Ni}-\mathrm{Cu}-\mathrm{Co}-\mathrm{PGE}$ mineralization occurs in both the Canwell Glacier (including Canwell, Forbes, and Emerick prospects) and the Eureka Glacier (Bird's Beak prospect) areas, and these prospects carry some of the highest PGE grades observed in the study area.

Our work provides evidence against the largescale feeder intrusion proposed by Glen and others (2011) on the basis of three-dimensional geophysical modeling. Glen and others (2011) proposed that the Amphitheater syncline represents a syn-volcanic sag basin with a greater-than-3-km-deep, keel-shaped feeder dike of ultramafic rock running along its axis. If real, this would be a structure of very great significance to the tectonics, petrology, and metallogeny of the area. However, our geologic mapping and interpretations are inconsistent with this hypothesis. The main point of inconsistency, discussed later in this report, is our interpretation that the Amphitheater Mountains greenstones and associated ultramafic complexes are a structural panel displaced at least $25 \mathrm{~km}$ along thrust faults. 
In our interpretation, the transported structural panel is not thick enough to host a deep ultramafic keel, and the structural footwall, comprising mostly Late Triassic Nikolai Greenstone and Permian sedimentary and volcanic rocks, is notable in its lack of mafic and ultramafic intrusions. Another discrepancy may be the physical properties used in the model. Glen and others (2011) model the Alpha (Fish Lake) ultramafic complex using a magnetic susceptibility value of $9,400 \times 10^{-6} \mathrm{cgs}\left(0.75 \times 10^{-3}\right.$ Système International [SI]), whereas field measurements by Lande (2016) during her detailed traverse across the complex indicate susceptibilities ranging from 2 to $100 \times 10^{-3} \mathrm{SI}$, depending on the degree of serpentinization. The higher magnetic susceptibility values obtained by Lande (2016) indicate a smaller volume of ultramafic rocks than that modeled by Glen and others (2011). It should be noted, however, that the gravity modeling presented by Glen and others (2011) predicts the deep ultramafic keel independently of the magnetic modeling. We have no basis to evaluate the gravity models except to state that the stratigraphy used in the models is inconsistent with the geology as mapped during our study.

\section{Northwest-vergent thrust faulting in the Talkeetna Mountains}

Mapping by DGGS in the central Talkeetna Mountains documented stratigraphic repetitions and an unusual total thickness for the Pennsylva- nian to Triassic Wrangellia stratigraphy (figs. 4, 9; Twelker and others, 2015a). The authors attribute this thickening and repetition to imbrication by a series of inferred, southeast-dipping thrust faults, similar to those noted between the central Talkeetna Mountains and Butte Creek area by Glen and others (2007).

Intensity of penetrative deformation and metamorphic grade increase from northwest to southeast, with amphibolite-facies gneissic rocks bounding Wrangellia along its southeastern margin (fig. 9). These higher-grade rocks, mapped as age-equivalent to the Strelna metamorphic complex, are interpreted to be metamorphosed volcanic and sedimentary rocks of Wrangellia (Wilson and others, 2015). Metamorphic cooling of both the amphibolite-facies rocks and the adjacent greenschist-facies rocks occurred during the Early Jurassic, as evidenced by ${ }^{40} \mathrm{Ar} /{ }^{39} \mathrm{Ar}$ cooling ages of $195 \mathrm{Ma}$ and $186 \mathrm{Ma}$ (hornblende and muscovite, respectively; Benowitz and others, 2015). A pair of mostly undeformed Late Jurassic plutons (163 Ma by U-Pb zircon; Todd and others, 2017) intrudes the southeastern edge of Wrangellia, apparently sealing the structure in Tsisi Creek ("Tsisi Creek fault"). The Late Jurassic plutons are subsequently cut by Cenozoic structures such as the late, brittle Central Raingellia fault (fig. 9).

As mapped (fig. 4; Twelker and others, 2015a), northwest-vergent thrust faults in the

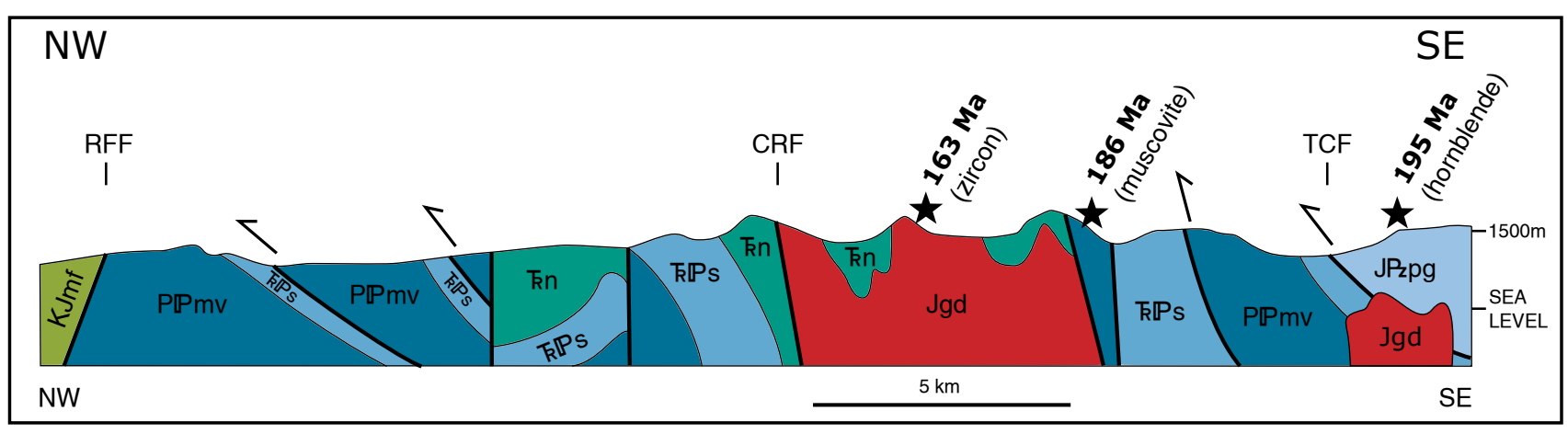

Figure 9. Cross section (no vertical exaggeration) through Wrangellia in the central Talkeetna Mountains (generalized from Twelker and others, 2015a). Abbreviations: RFF - Range Front fault; CRF - Central Raingellia fault; TCF - Tsisi Creek fault. See figure 4 for geologic legend and cross section location. Zircon age is from Todd and others (2017); muscovite and hornblende ages are ${ }^{40} \mathrm{Ar} /{ }^{39} \mathrm{Ar}$ metamorphic cooling ages (Benowitz and others, 2015). 
central Talkeetna Mountains cut rocks at least as young as the Late Triassic Nikolai Greenstone. If the contractional tectonics causing the thrusting also caused the metamorphic cooling of the higher-grade ("hinterland") rocks, the timing of the northwest-directed shortening is likely to be Early to Middle Jurassic. This timing is compatible with our mapping, indicating that Late Jurassic plutons (unit Jgd) seal the Tsisi Creek structure (fig. 4).

If shortening occurred during the Early to Middle Jurassic, it would have preceded the accretion of Wrangellia to the North American margin, a progressive collisional event occurring from the Late Jurassic into the early Late Cretaceous (Trop and Ridgeway, 2007). If this is the case, the northwest-vergent thrusting observed in the central Talkeetna Mountains might reflect shortening between the Wrangellia and Peninsular terranes. Alternatively, if we are incorrect and the northwest-directed thrust faults in the central Talkeetna Mountains are younger, they may be related to mid-Cretaceous northwest-vergent thrust faults mapped by Hampton and others (2007) in the northwestern Talkeetna Mountains. These faults cut Triassic to Early Cretaceous strata including the Honolulu Pass Formation and the Kahiltna Formation (maximum depositional age ca. $120 \mathrm{Ma}$ ), and deform the Albian or younger Caribou Pass Formation.

\section{Talkeetna suture zone and parallel structures in the central Talkeetna Mountains}

According to the reconnaissance-scale geologic map of Csejtey and others (1978), the northwestern boundary of Wrangellia is the Talkeetna thrust, a regional-scale structure emplacing Paleozoic through Triassic rocks of Wrangellia over Cretaceous metasedimentary rocks of the Kahiltna assemblage. The USGS Talkeetna Mountains Transect project revised this model through mapping and geophysical modeling (Glen and others, 2007), redefining the Talkeetna thrust as the Talkeetna suture zone, a deep-seated crustal boundary that is expressed at surface through a variety of high-angle faults, pull-apart basins, reverse fault-bounded uplifts, and topographic lineaments (O'Neill and others, 2005). The distribution, orientation, and history of faults in this area is of particular importance because of possible hazards posed to hydropower development on the Susitna River in the immediate vicinity of the Talkeetna suture zone.

Mapping by DGGS (figs. 4, 10; Twelker and others, 2015a) over the Talkeetna suture zone supports the findings of Glen and others (2007) in that it failed to locate a northwest-vergent Talkeetna thrust fault. Instead, the Permian to Triassic stratigraphy of Wrangellia, metamorphosed to lower greenschist facies, is juxtaposed against Jurassic to Cretaceous metasedimentary rocks across the Range Front fault (fig. 10). Petrography shows that the Jurassic to Cretaceous metasedimentary rocks have a metamorphic fabric including aligned biotite, indicating at least local metamorphism to amphibolite facies. Davidson and McPhillips (2007) describe similar lower amphibolite-facies contact metamorphism and latest Cretaceous plutons in the vicinity of Devil Creek, approximately $25 \mathrm{~km}$ to the north of the area sampled by DGGS. Geothermobarometry of the Devil Creek rocks indicate metamorphism at approximately 3 kilobars (Davidson and McPhillips, 2007).

Medium- to coarse-grained granodiorite plutons of Paleocene age (63 Ma by U-Pb zircon; Todd and others, 2017) intrude the amphibolite-facies metasedimentary rocks north of the Range Front fault (fig. 10). Plutons of this composition and age do not intrude Wrangellia rocks south of the Range Front fault; however, a dacite porphyry dike dated at $68 \mathrm{Ma}$ (Benowitz and others, 2015) intrudes Wrangellia south of the Range Front fault. The presence of these hypabyssal dacite porphyry dikes (fig. 10) suggests that the rocks south of the Range Front fault were exhumed to a shallow crustal level by latest Cretaceous, while amphibolite-facies metasedimentary rocks and granodiorite plutons north of the Range Front fault remained at an intermediate crustal level through the Paleocene. The metasedimentary and plutonic rocks north of 


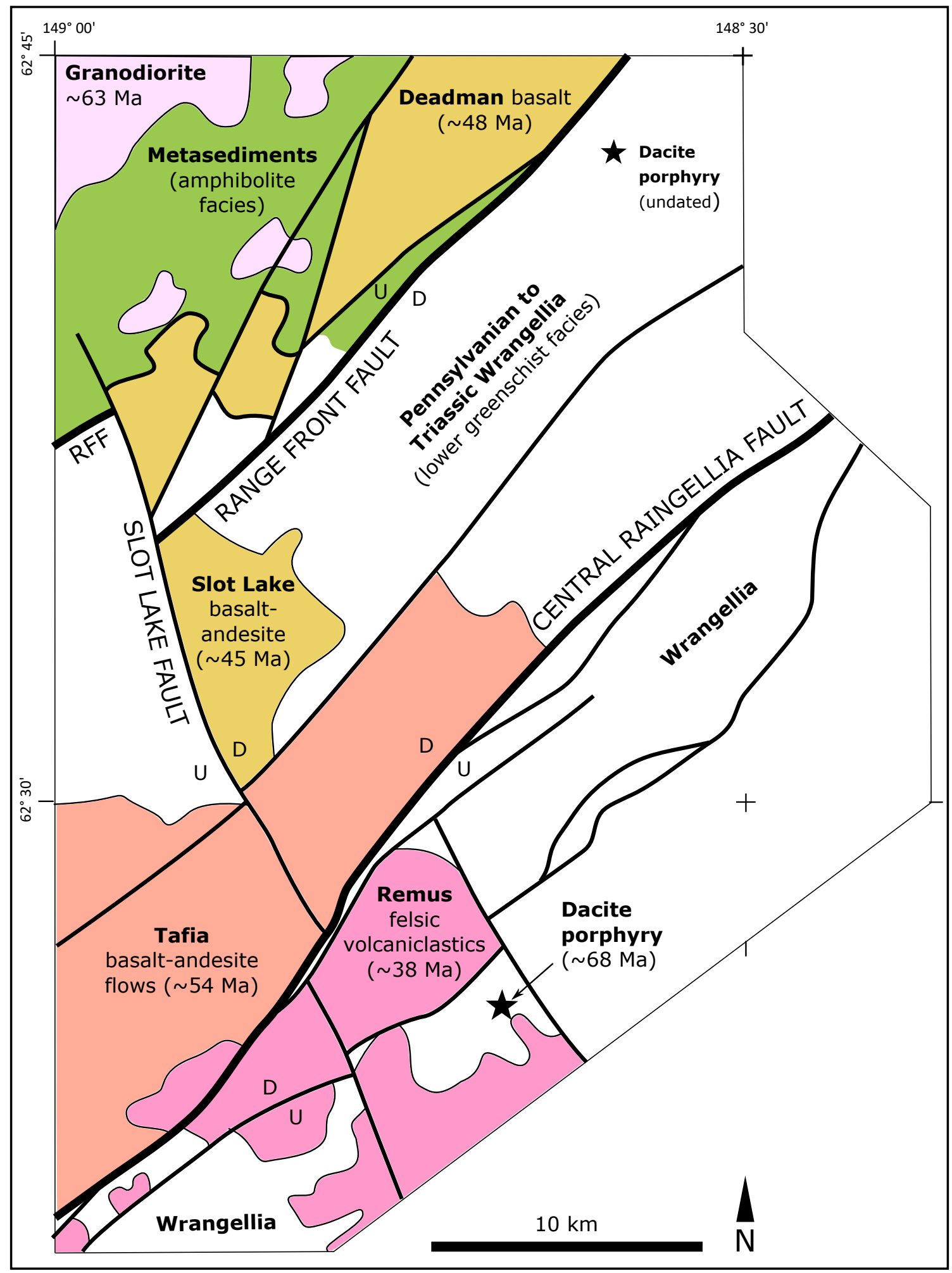

Figure 10. Simplified interpretive geologic map of the central Talkeetna Mountains (modified from Twelker and others, 2015a) showing major fault systems (black lines) and selected Cretaceous and younger geologic map units; pre-Cretaceous rock units (mostly Wrangellia terrane) are uncolored. Stars are locations of the dacite porphyry intrusions. 
the Range Front fault were then exhumed to surface prior to the deposition of the Deadman volcanic sequence at around $48 \mathrm{Ma}$ (Schmidt and others, 2002). While much remains to be constrained, these data suggest a roughly $10-\mathrm{km}$ dip-slip component of displacement (north side up) on the Range Front fault strand of the Talkeetna suture zone during the Paleogene. DGGS mapped the ca. 45 Ma unconformity and volcanic fields on both sides of the Range Front fault (fig. 10), evidence that suggests no major dip-slip activity has occurred on the Range Front fault strand since that time.

The Range Front fault is truncated by the north-northwest-striking Slot Lake fault (fig. 10). This fault cuts volcanic fields, the Slot Lake and Remus volcanic sequences (Twelker and others, 2015a), dated at $45 \mathrm{Ma}$ (Oswald, 2006) and 38 $\mathrm{Ma}$ (Benowitz and others, 2015), respectively. It is itself offset by about $1.6 \mathrm{~km}$ in a right-lateral (apparent) sense by the northeast-striking Central Raingellia fault (fig. 10).

The Central Raingellia fault is a complex highangle fault system with multiple episodes of slip, including both ductile deformation and brittle overprint (Sicard and others, 2015); its relationship to a succession of Paleogene volcanic fields places some constraint on the brittle portion of its history. The Central Raingellia fault juxtaposes an up-to-1-kmthick package of Tafia volcanic sequence basalt to andesite, dated at around $54 \mathrm{Ma}$ (Benowitz and others, 2015), against the predominantly felsic Remus volcanic sequence, dated at around $38 \mathrm{Ma}$ (Benowitz and others, 2015). The Remus volcanic sequence partially overlaps the Central Raingellia fault and the adjacent Tafia sequence, as apparent in cross section C of Twelker and others (2015a). From these cross-cutting relationships and the absence of the Tafia volcanic sequence to the southeast, we infer that the Central Raingellia fault experienced greater than $1 \mathrm{~km}$ of apparent southeast-side-up offset after $54 \mathrm{Ma}$ and before $38 \mathrm{Ma}$ (since the Remus volcanic sequence apparently overlaps the fault). A further $1.6 \mathrm{~km}$ of right-lateral offset occurred on the Central Raingellia fault after $38 \mathrm{Ma}$. This right-lateral sepa- ration is not apparent on the Range Front fault, which is crosscut by the Slot Lake fault (fig. 10).

These crosscutting relationships suggest that significant fault activity, possibly related to the deepseated Talkeetna suture zone, shifted from the Range Front fault to the Central Raingellia fault sometime after $45 \mathrm{Ma}$. We infer that there could be some component of more recent dip-slip offset on the Range Front fault because it follows a break in present-day topographic relief between the Fog Lakes lowland and the hills to the southeast. However, the amount of dip slip is constrained by the presence of the ca. $45 \mathrm{Ma}$ unconformity and volcanic fields on both sides of the fault, and the amount of strike slip is severely limited by the crosscutting Slot Lake fault.

\section{South-vergent thrust faulting in the southern Alaska Range}

Based on our interpretation of the geology in light of recently acquired geophysical and geochemical datasets, we support the basic interpretation of Nokleberg and others (1985) that the Nikolai Greenstone in the vicinity of the Amphitheater Mountains and Paxson Mountain has been duplicated on a large-scale thrust fault (Fish Lake thrust; fig. 11). This structural relationship indicates a minimum of $20 \mathrm{~km}$ north-south shortening, and we interpret this shortening to be part of the Late Cretaceous to Cenozoic contractional tectonics associated with the Alaska Range suture zone.

Stout (1976) mapped thick sections of Paxson Mountain Basalt at Paxson Mountain, in the Eureka Creek area, and in the area of low relief east of Lower Tangle Lake. Whole rock geochemistry of these rocks indicates a basaltic composition, elevated $\mathrm{Ti}$, and an enriched REE profile (Twelker and others, 2014) consistent with the upper, high-Ti member of the Nikolai Greenstone (kn2). These rocks also have a high magnetic susceptibility that is characteristic of upper Nikolai Greenstone and not characteristic of the Paleozoic mafic metavolcanic sequence (PPmv).

The high magnetic susceptibility of the upper Nikolai Greenstone allows it to be traced in 
geophysical surveys (Burns and others, 2003) under Cenozoic sedimentary cover in the Delta River and Fielding Lake area. Between the mapped exposures and the geophysical interpolation, the upper Nikolai Greenstone borders the westward-plunging Amphitheater syncline on three sides (fig. 11). Geophysical modeling of the very high magnetic susceptibility ultramafic rocks indicates dips towards the center of the syncline (Glen and others, 2011). The same geophysical pattern and interpretation also apply to the ultramafic rocks at the nose (east-southeast end) of the syncline: the ultramafic rocks do not project under Paxson Mountain; rather, they overlie the upper Nikolai Greenstone and project over Paxson Mountain. Additionally, deep exploration core drilling near the edges of the Alpha (Fish Lake) ultramafic complex (Pure Nickel drill hole PNI 10-30) succeeded in penetrating the ultramafic and exiting into the underlying upper member of the Nikolai Greenstone. To achieve this juxtaposition, the Early Permian sedimentary rock that hosts the Late Triassic Alpha ultramafic complex must have been thrust over the Late Triassic Nikolai Greenstone. The relationship cannot be explained by a large-scale overturned fold because mapping relationships indicate that the Nikolai Greenstone section is upright ( $\mathrm{kn} 2$ overlies $\mathrm{kn} 1$ ) in both the Amphitheater Mountains and the Eureka Creek area (fig. 11).

Detailed mapping by Lande (2016) shows that the Alpha ultramafic complex becomes progressively more serpentinized towards its northern (basal) contact (fig. 12). While the northern margin of the Alpha complex in the vicinity of mapping is a minor high-angle fault, we interpret the serpentinization at its base to be a result of its proximity to the Fish Lake thrust (fig. 11).

In the eastern Alaska Range, the Broxson Gulch fault separates Triassic and older stratigraphy of Wrangellia from Jurassic to Cretaceous metasedimentary rocks of the Maclaren metamorphic belt; it occupies the same structural position as the Talkeetna shear zone and in some ways is a continuation. The fault has been ascribed an extended history and wide-ranging tectonic significance (Nokleberg and others, 1985) that are beyond the scope of this report.

Figure 13 presents a possible model for the assembly of the Rainy Creek-Amphitheater Mountains area. We divide Wrangellia into three blocks based on structural and stratigraphic characteristics. The Paxson Mountain block contains a nearly complete Wrangellia section, excluding post-Nikolai Greenstone sedimentary rocks. This block hosts no ultramafic rocks and very few gabbro sills, and it is autochthonous in the context of our fault model. The Amphitheater block contains a typical Nikolai Greenstone section comparable to that of the Paxson Mountain block; cross section interpretations (Twelker and others, 2020) suggest that this panel is about $5 \mathrm{~km}$ thick. It lacks the Pennsylvanian-Permian volcanic units, and it overlies the Paxson Mountain block on the Fish Lake thrust. Both the Amphitheater and Rainy Creek blocks host abundant ultramafic and mafic sills. The Rainy Creek block differs from the Amphitheater block by the presence of Rainy Creek picrite in the place of typical Nikolai Greenstone (units kn1, kn2); we attribute this difference to the primary magmatic and volcanic environment. This block is floored by the Rainy Creek thrust and imbricated by related faults. Prior to the youngest deformation, the Fish Lake thrust and the Rainy Creek thrust may have been connected and served as the floor thrust in a large-scale duplex (fig. 13). The Broxson Gulch fault, which separates Wrangellia from JurassicCretaceous metasedimentary rocks, may occupy the position of roof thrust.

The Fish Lake thrust, the Rainy Creek thrust, and related faults together accommodate significant shortening. Restoration of stratigraphic continuity between the Amphitheater and Paxson Mountain blocks requires a minimum of $20 \mathrm{~km}$ displacement (the measured length of the Fish Lake thrust on the cross section in fig. 11). Shortening within the Rainy Creek block is less constrained, but it could easily be greater than $10 \mathrm{~km}$. Possible shortening between the Rainy Creek and Amphitheater blocks is entirely unconstrained. 


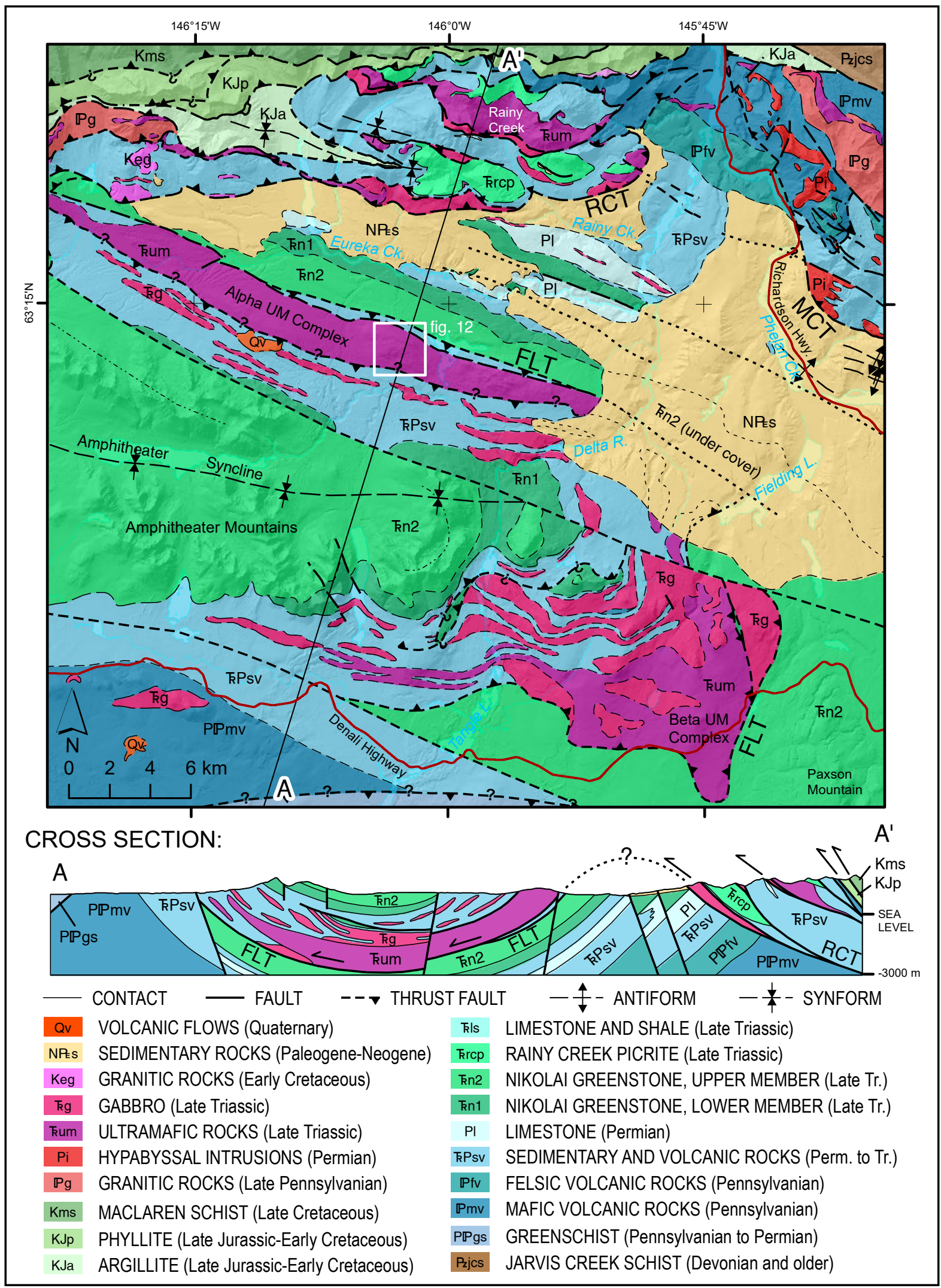

Figure 11. Geologic map and cross section of the Amphitheater Mountains-Rainy Creek area (after Twelker and others, 2020). The cross section is at the same scale as the map; no vertical exaggeration. Thrust fault name abbreviations: FLT - Fish Lake thrust; RCT - Rainy Creek thrust; MCT - McCallum Creek thrust. 


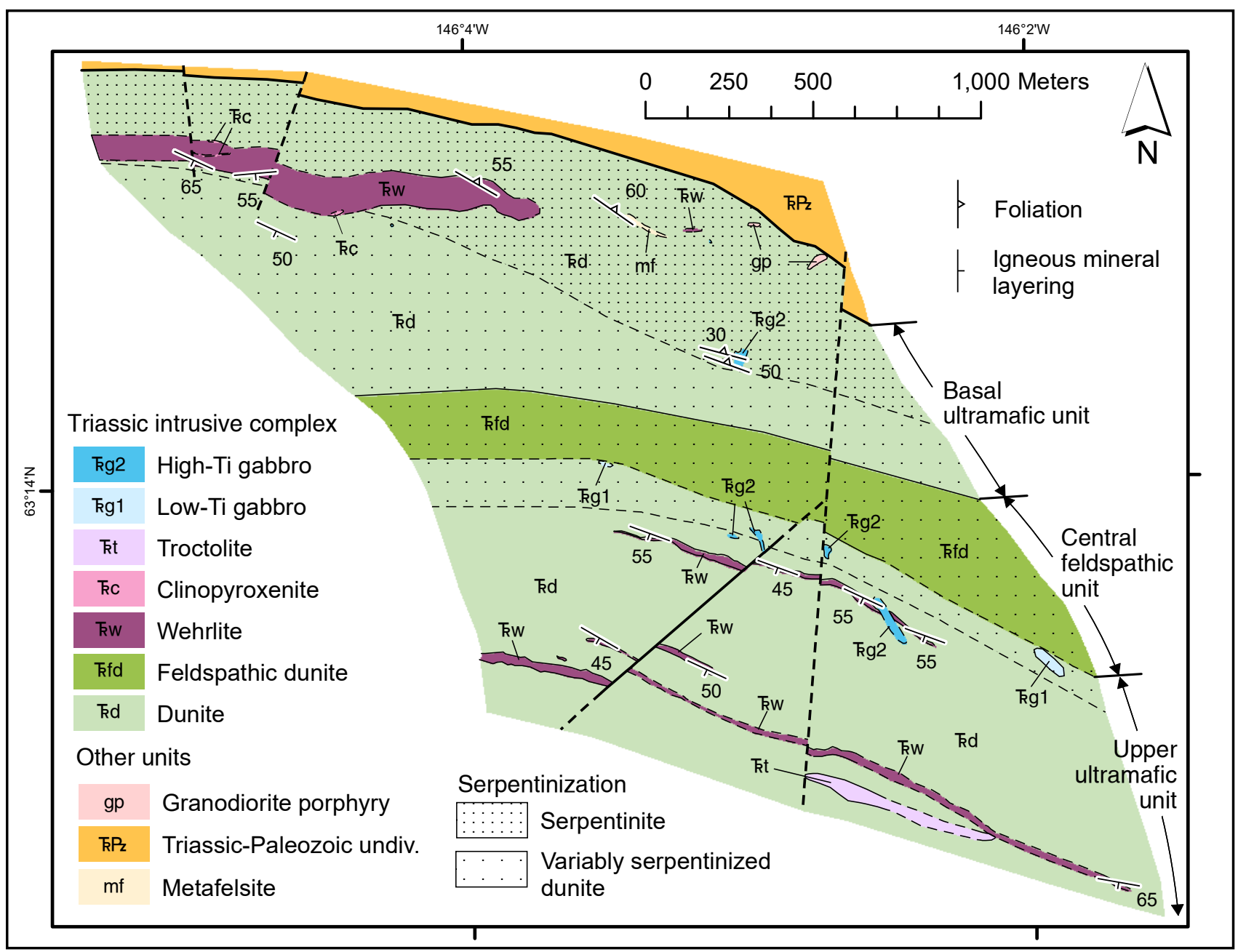

Figure 12. Detailed geologic map of the central Alpha mafic-ultramafic intrusive complex at VABM Wild (Lande, 2016). Location of complex is shown in figure 11. Measurable magmatic contacts and layering dip approximately 50 degrees to the south; the base of the complex is to the north.

Identifying the timing of north-south shortening is complicated, because the present-day thrust-stacking configuration apparently reflects multiple phases of contractional deformation, including reactivation of existing faults. There is clear evidence for fault activity during the Neogene, which is constrained by crosscutting relationships with and deformation of Paleogene conglomerates (maximum depositional ages of $28 \mathrm{Ma}$ and 51 Ma; Waldien and Roeske, 2017). Similar Cenozoic conglomerates (lacking local age control) overlap the Fish Lake thrust, which therefore must have experienced its major slip prior to their deposition.

Early phases of south-directed thrust faulting could have accompanied the accretion of Wrangellia to North America-derived rocks (Maclaren schist) along the Valdez Creek shear zone. This shear zone experienced top-south motion during the Late Cretaceous (Davidson and others, 1992). Such a shear could have the potential to drive large-scale, south-directed shortening of the footwall stratigraphy on subsidiary structures such as the Fish Lake thrust. Alternatively, the shortening could have been north-directed and similar in timing to the Jurassic(?) northwest-vergent shortening described in the Talkeetna Mountains (see above).

\section{Young high-angle faults}

New bedrock geologic map interpretations completed as part of this project highlight a series of high-angle faults with west-northwesterly strikes 


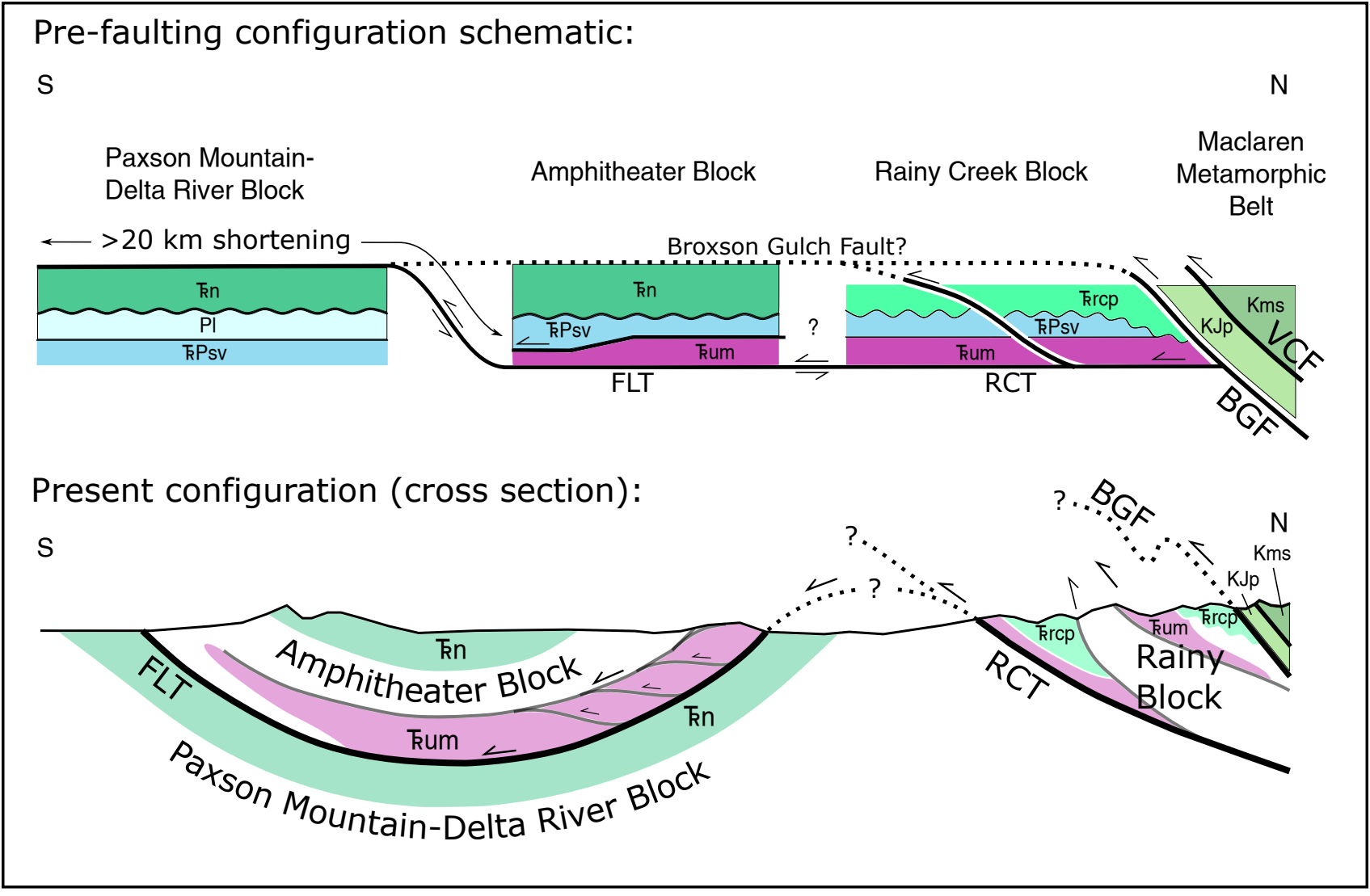

Figure 13. Proposed structural assembly of the Amphitheater Mountains-Rainy Creek area. The upper schematic illustrates the pre-faulting configuration; note that both Paxson Mountain and Amphitheater panels have thick sections of Nikolai Greenstone ( $(\mathrm{kn})$, and Amphitheater Mountains and Rainy Creek panels both contain volumetrically significant ultramafic intrusions. Slivers of Maclaren Schist (Kms) imbricated within Amphitheater and Rainy Creek blocks suggest that this unit was once in the footwall of the Fish Lake thrust (FLT) and Rainy Creek thrust (RCT). The present configuration with the Amphitheater block thrust over the Paxson Mountain-Delta River block indicates a minimum of 20 km shortening; additional shortening is indicated by repeated section within the Rainy Creek block.

that occur in the area between the Susitna River and the Denali fault (fig. 3; Twelker and others, 2020). These faults mainly affect rocks in the Wrangellia terrane, and they are particularly visible in airborne magnetic surveys, cutting the high magnetic susceptibility Nikolai Greenstone. They also notably affect mineral-resource exploration areas at the Alpha complex and Zackly prospects.

Stratigraphic relationships across these west-northwest-striking faults indicate significant dip-slip offsets (labeled in fig. 14). Kinematic indicators suggest both dip-slip and dextral strike-slip displacements. We observed normal brittle dip-slip kinematic indicators (with a few high-angle reverse kinematic indicators) at field exposures along
Eureka Creek. Waldien (2015) observed northside-up apparent offset on the Hoodoo fault (HF in fig. 14) but concluded from fault surface analysis that dextral kinematic indicators predominate.

Motion on these west-northwesterly faults is probably Cenozoic, possibly Neogene, in timing; it is constrained by crosscutting relationships with the Fish Lake thrust (fig. 14). The west-northwesterly faults may also cut the other, younger thrust sheets, including the Rainy Creek thrust and the McCallum Creek thrust; however, this interpretation is driven by airborne resistivity data and has not been fully vetted through geologic mapping. Within the thrust-affected area of Rainy Creek, the Airstrip fault (ASF in fig. 14) is a possible candidate for inclusion in the 
west-northwesterly fault group due to its orientation and relatively small displacement. This is an alternative interpretation to that presented by Waldien and Roeske (2017) and Twelker and others (2020). The west-northwesterly faults appear to be covered by at least the youngest of the sedimentary rocks in the McCallum basin (Pliocene; Allen, 2016).

The series of west-northwesterly faults suggests a horst-and-graben architecture-a localized extensional or transtensional environment-lying at the foot of the contemporaneously shortening Alaska Range. The direction of extension, northeast-southwest, is consistent with the accommodation of right-lateral displacement along the Talkeetna suture zone (discussed above; Glen and others, 2007).
Right-lateral shear across the suture zone is inferred during the Paleogene based on the geometry of systems of shallow, brittle faults developed above suture in the northern Talkeetna Mountains (O'Neill and others, 2005). Some amount of right-lateral displacement along the Talkeetna suture zone may be expected during Neogene to present time, based on the sense of motion of similarly oriented adjacent faults (Denali and Castle Mountain faults; fig. 14 inset) in response to the collision of the Yakutat block and the rotation of south-central Alaska through the Denali fault restraining bend. These young, west-northwesterly extensional or transtensional faults may reflect a Neogene phase of right-lateral motion on the Talkeetna suture zone system.

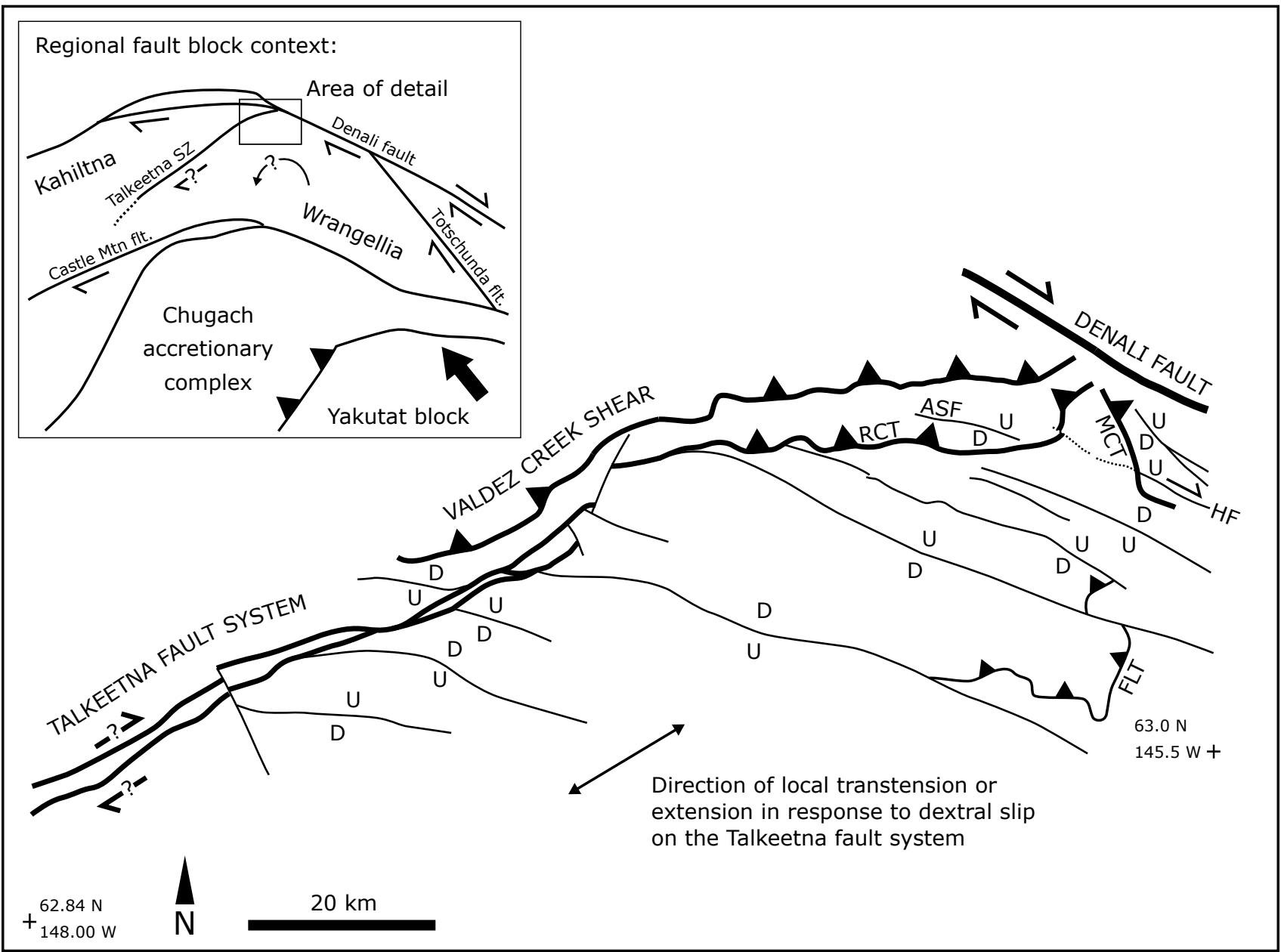

Figure 14. Simplified fault map (after Twelker and others, 2020) showing the series of high angle normal faults south of the Talkeetna-Valdez Creek-Broxson Gulch fault system. The inset at upper right shows the regional context of the Wrangellia terrane in central Alaska. Abbreviations: FLT - Fish Lake Thrust; RCT - Rainy Creek thrust; MCT - McCallum Creek thrust; HF - Hoodoo fault; ASF - Airstrip fault. 


\section{MAGMATIC-GEOCHEMICAL FRAMEWORK OF NI-CU-CO-PGE MINERALIZATION}

\section{Major element geochemistry}

Lithogeochemical samples of the Nikolai Greenstone comprise high- and low-Ti groups, which have stratigraphic as well as geochemical distinctions (Greene and others, 2008; Twelker and others, 2015a). High-Ti volcanic rocks (kn2) of the Nikolai Greenstone overlie low-Ti volcanic rocks (kn1), where present (fig. 5). The most primitive volcanic samples, the Rainy Creek picrites, are confined to the area north of the Rainy Creek thrust (displacement unknown; figs. 13, 15) and hence are treated separately despite many geochemical similarities with the high-Ti series rocks.
The major-element compositions of mafic volcanic rocks and non-cumulate gabbro sills are predominantly subalkaline, basaltic, and contain from 46 to 54 percent $\mathrm{SiO}_{2}$ (fig. 16A). The most primitive extrusive samples contain 12 to 20 percent $\mathrm{MgO}$ and are therefore picrites under the revised IUGS classification for high- $\mathrm{MgO}$ volcanic rocks (fig. 16B; LeBas, 2000). Rocks sampled by DGGS cover a nearly continuous range of compositions from picrite to basaltic andesite.

Values of $\mathrm{Mg} \#\left(100^{*}[\right.$ molar $\mathrm{MgO} /(\mathrm{MgO}+$ $\mathrm{FeO})]$ ) range from a high of 82 in the most primitive picrites to a low of 44 among the more evolved basalt and gabbro. This variation is characteristic of tholeiitic magmas and enables our use of the $\mathrm{Mg}$ \# as a monitor of fractionation (fig. 17). Concentrations of $\mathrm{MgO}$ show a strong positive correlation with

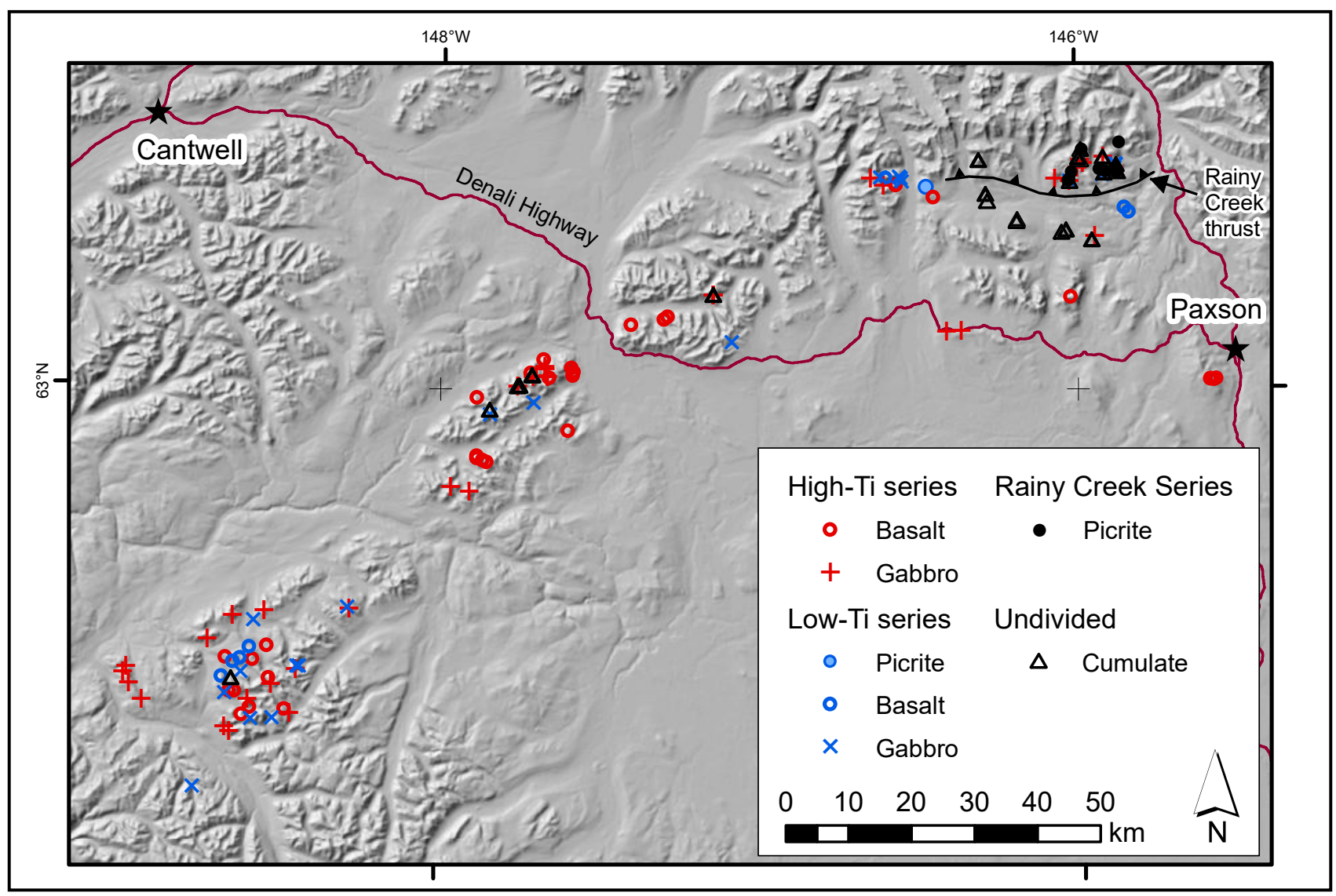

Figure 15. Map showing the distribution of whole-rock geochemical samples of Late Triassic mafic and ultramafic rocks generated for this project (Twelker and others, 2014a; Wypych and others, 2014, 2015). Both high- and low-Ti series samples are widely distributed, while the Rainy Creek series picrite samples are restricted to the area north of the Rainy Creek thrust. Cumulate ultramafic samples are preferentially clustered at the eastern end of the study area. 

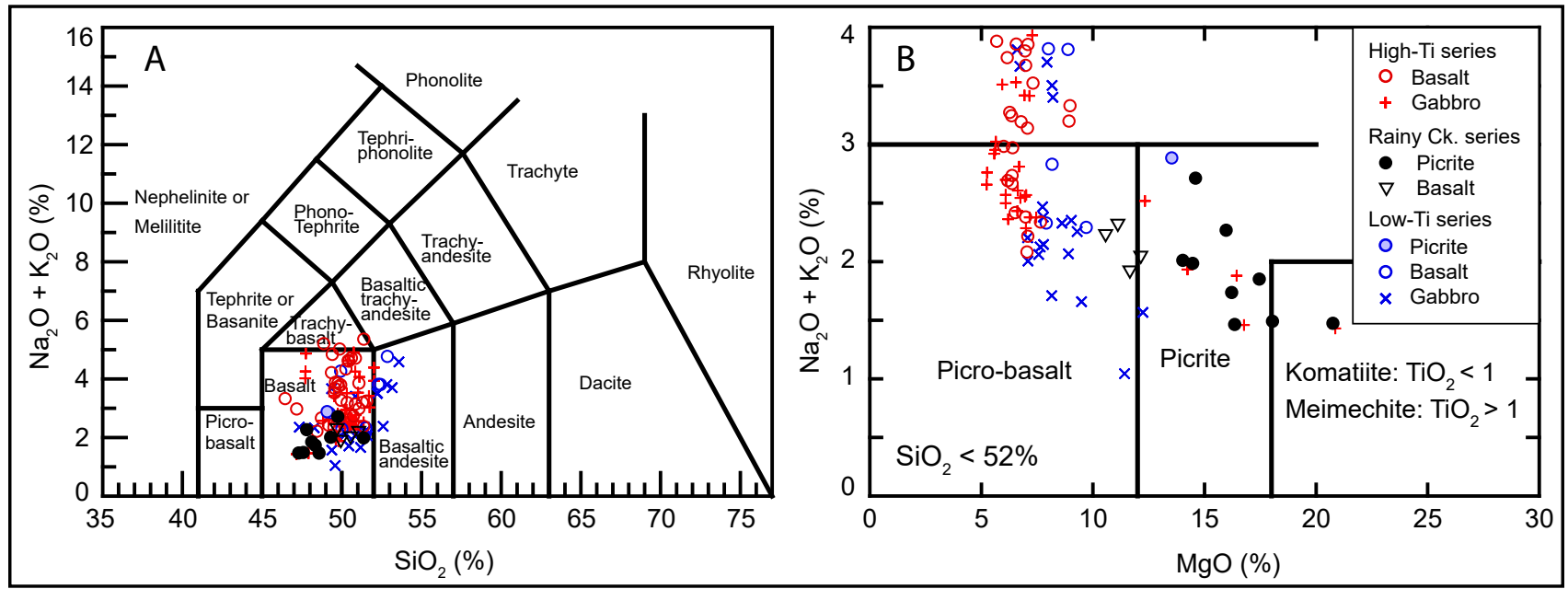

Figure 16. IUGS classification diagrams illustrating the major element compositions of non-cumulate rocks. A. Total alkalis versus silica diagram of Le Maitre and others (1989). B. Total alkalis versus MgO for rocks with less than 52 percent $\mathrm{SiO}_{2}$ (LeBas, 2000).

$\mathrm{Mg}$ \#, decreasing with increasing magma evolution (decreasing $\mathrm{Mg} \#$ ) and monitoring the fractionation of Mg-rich olivine and pyroxene phases.

Concentrations of $\mathrm{TiO}_{2}$ plotted against $\mathrm{Mg} \#$ show two separate and parallel trends. This observation supports that of Greene and others (2008), who defined high-Ti and low-Ti suites as discussed above. The most primitive "parent" magmas of the low-Ti suite average 0.45 percent $\mathrm{TiO}_{2}$, while the similarly primitive Rainy Creek picrite (a member of the high-Ti suite in terms of most, but not all, trace element characteristics) averages 1.08 percent $\mathrm{TiO}_{2} \cdot \mathrm{TiO}_{2}$ concentrations for the two series overlap when considered in their entirety.

$\mathrm{Al}_{2} \mathrm{O}_{3}$ concentrations (fig. 17) indicate an additional contrast between the compositions of the high- and low-Ti series rocks. Picrites of the Rainy Creek series have an average of 10.5 percent $\mathrm{Al}_{2} \mathrm{O}_{3}$, compared with 15.7 percent $\mathrm{Al}_{2} \mathrm{O}_{3}$ for picrites of the low-Ti series. $\mathrm{Al}_{2} \mathrm{O}_{3}$ increases with decreasing $\mathrm{Mg}$ \# for the most primitive Rainy Creek samples, while the low-Ti series and the less primitive high-Ti samples collectively show a slight decreasing trend.

Total alkalis $\left(\mathrm{Na}_{2} \mathrm{O}+\mathrm{K}_{2} \mathrm{O}\right)$ show a rough increasing trend with decreasing $\mathrm{Mg}$ \#; however, there is a large degree of scatter, which we inter- pret to reflect the relatively high mobility of these elements under conditions of lower greenschist facies metamorphism.

Cumulate samples, identified by textural and compositional criteria, form a trend between picrite compositions and dunite (greater than 90 percent cumulate olivine), with up to 43 percent $\mathrm{MgO}$ and less than 1 percent $\mathrm{CaO}$ (fig. 18). Cumulate rocks also show progressive enrichment in $\mathrm{Cr}$ that is generally correlated with increasing $\mathrm{MgO}$.

\section{Trace elements}

Variations in trace elements reflect the processes that also control variations in major elements and highlight the effects of other aspects of the magmatic system. Incompatible high-fieldstrength elements (HFSE) such as Zr, Y, and Th are conserved in the melt during crystallization of olivine and clinopyroxene, increasing in relative concentration from initial primitive values with progressive magma fractionation. Ratios between the HFSE are preserved, however, and our data clearly show differences in the initial HFSE content of the high- and low-Ti suite rocks. Primitive picrite samples plot near the low-concentration end of the respective trends defined by high- and low-Ti series rocks in terms of $\mathrm{Zr}$ versus $\mathrm{Y}$ (fig. 19). Other plots ( $\mathrm{Nb}$ vs. $\mathrm{Y}, \mathrm{Ti}$ vs. $\mathrm{Y}, \mathrm{Ce}$ vs. $\mathrm{Yb}$, etc.) show similar 


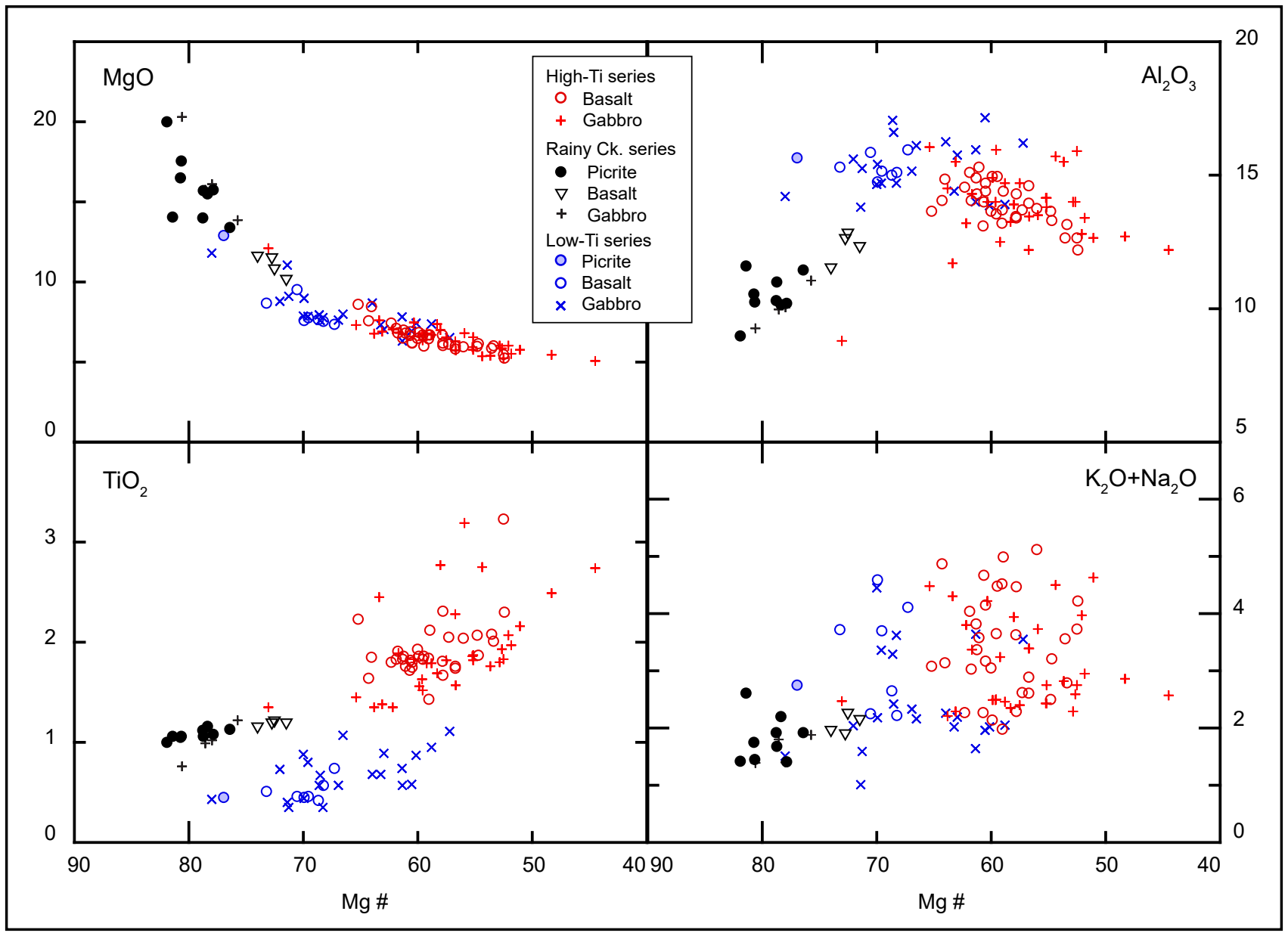

Figure 17. Selected major-element-oxide trends for non-cumulate rocks plotted against Mg \# (100*[molar MgO/(MgO+FeO)]); vertical axes values given in percent.

patterns. In contrast, plots of Th vs. $\mathrm{Zr}$ (or other HFSE) show that picrites and basalts of the Rainy Creek group have a higher $\mathrm{Th} / \mathrm{Zr}$ ratio than do the normal high-Ti basalts and gabbros (fig. 19).

As with the HFSE, rare earth element (REE) patterns for non-cumulate samples reflect the contrast between the high- and low-Ti groups. Normalized to chondrite values (Sun and McDonough, 1989), high-Ti series rocks show a consistent pattern of moderate light-rare-earth-element (LREE) enrichment (fig. 20). Similar to those in other incompatible elements, REE concentrations of high-Ti basalts and gabbros are approximately 50 percent higher than those of high-Ti picrites. REE for low-Ti series rocks show a much greater degree of scatter than do those for the
high-Ti samples (fig. 20). Many samples indicate moderate LREE depletion, while some are characterized as flat through the middle REE with a weak enrichment in the LREE.

Measurable quantities of some REE occur in many of the cumulate samples that crystallized some fraction of melt in addition to cumulate olivine, which is assumed to have negligible REE and acts strictly as dilution of REE-bearing melt. Figure 21A shows $\mathrm{Ce}$ versus $\mathrm{Yb}$ abundances for high- and low-Ti melts. Olivine cumulates and samples with elevated $\mathrm{Pt}$ values maintain the $\mathrm{Ce} /$ $\mathrm{Yb}$ ratio of the high-Ti series rocks. Similarly, figure $21 \mathrm{~B}$ shows that the vast majority of olivine cumulates and $\mathrm{Pt}$-mineralized samples maintain the Ti/Y ratio of the high-Ti series magmas. 


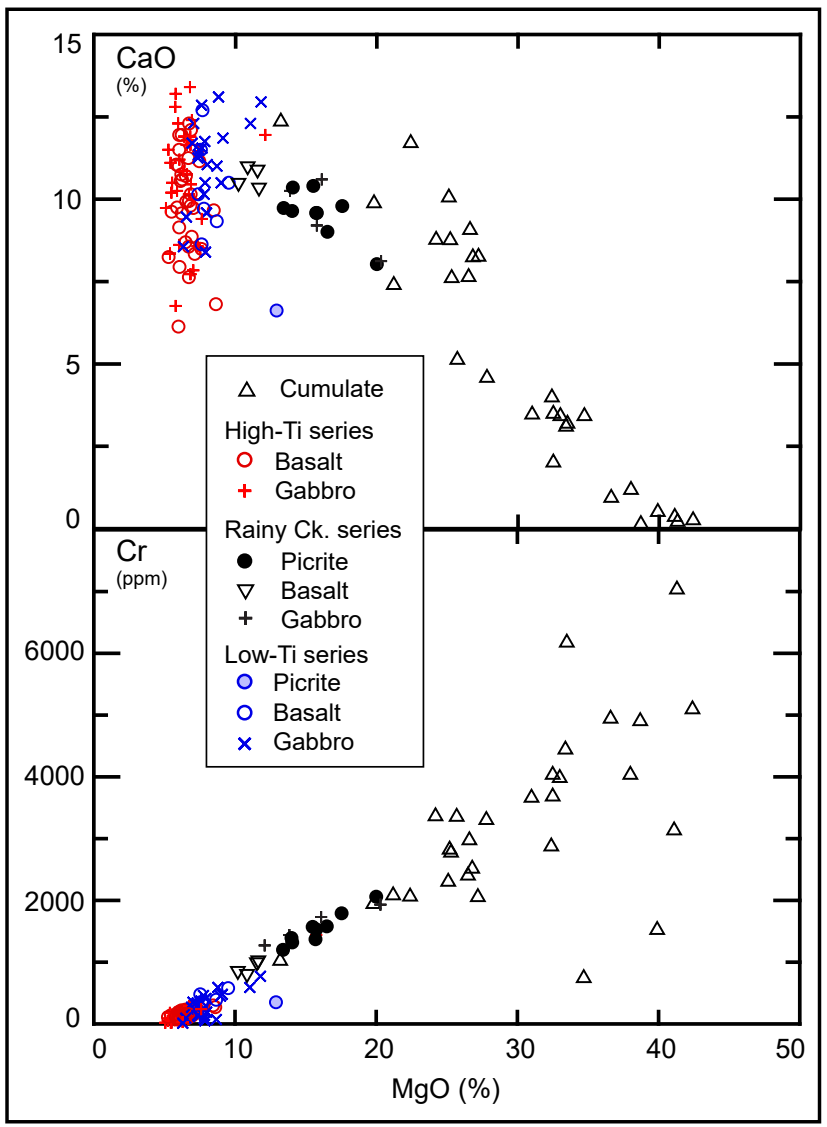

Figure 18. Bivariate scatterplot of $\mathrm{CaO}$ and $\mathrm{Cr}$ versus $\mathrm{MgO}$ for cumulate and non-cumulate samples.

\section{Platinum-group and chalcophile elements}

The lithogeochemical analyses assembled for this study include high-precision measurements of $\mathrm{Pt}, \mathrm{Pd}$, and Au concentrations, as well as suitably precise determinations for the more common ore elements $\mathrm{Ni}, \mathrm{Cu}$, and $\mathrm{Co}$. These elements exhibit a variety of lithophile, chalcophile, and siderophile properties that shed light on processes at work in the magmatic system.

$\mathrm{Ni}$ exhibits lithophile behavior and decreases in concentration with increasing magma evolution (decreasing $\mathrm{Mg}$ \#; fig. 22). Ni concentrations decrease sharply with evolution of the primitive Rainy Creek series samples, and less sharply for more evolved samples with $\mathrm{Mg}$ \# lower than 70. The low-Ti series characteristically has lower $\mathrm{Ni}$ concentrations at higher $\mathrm{Mg} \#$ and follows a slightly different trajectory.

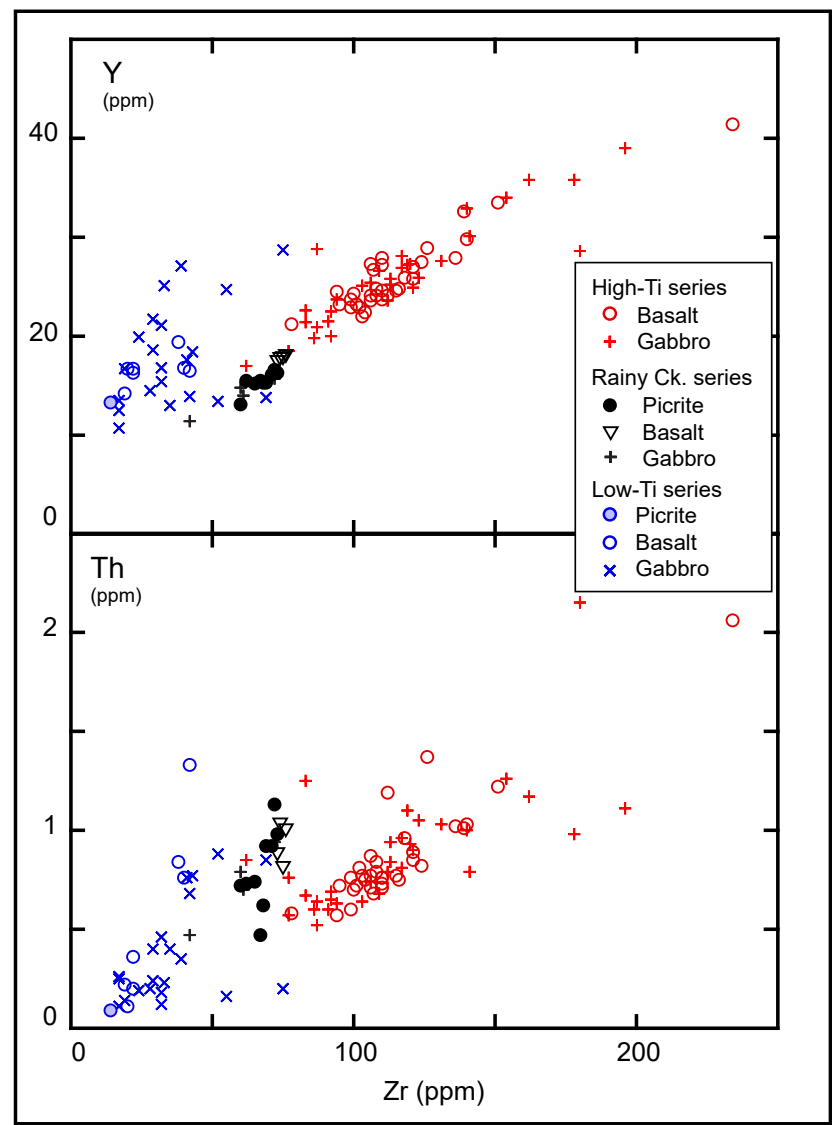

Figure 19. Bivariate scatterplot of selected HFSE elements $\mathrm{Zr}, \mathrm{Y}$, and Th in non-cumulate samples.

$\mathrm{Pt}$ and $\mathrm{Pd}$ data suggest concentrations of about 11 parts per billion (ppb) Pt and $9 \mathrm{ppb} \mathrm{Pd}$ were present in the most primitive samples, with no discernable difference between the Rainy Creek and low-Ti series. Plotted against Mg \#, Pt values decrease with progressive magma evolution (fig. 22), indicating compatible behavior; this relationship is most clear for rocks of the high-Ti series. In contrast, $\mathrm{Pd}$ values increase with progressively lower $\mathrm{Mg}$ \#, incompatible behavior that suggests $\mathrm{Pd}$ is conserved in the melt during magma evolution.

Increasing Pd with magma evolution is paralleled by a similar trend for $\mathrm{Cu}$. Cu exhibits much greater scatter, which may reflect greater hydrothermal mobility during devitrification and lower greenschist-facies metamorphism. The lower degree of scatter observed for gabbros in comparison to that of basalts (fig. 22), particularly in the high-Ti series, may reflect the fundamental resistance to fluid flow 
of a crystalline igneous rock versus that of an initially glassy sequence of volcanic flows and flow breccias.

Some samples show strong Pt and Pd depletion relative to the normal trends (fig. 22). A few samples fall below detection and are represented by one-half the detection limit $(0.5 \mathrm{ppb} \mathrm{Pt}$ and 1 ppb Pd). PGE-depleted samples are from both high- and low-Ti series, and are generally depleted in both Pt and Pd (figs. 22, 23). The PGE-depleted samples are geographically scattered throughout the study area; all strongly depleted samples in our dataset are gabbros or cumulate ultramafic rocks.

Characteristic Pt/Pd ratios vary according to rock type (fig. 23). Rainy Creek-series picrite and basalt average $\mathrm{Pt} / \mathrm{Pd}$ of 1.1 , while low-Ti series rocks average $\mathrm{Pt} / \mathrm{Pd}$ of 1.2. High-Ti series basalts and gabbros average $\mathrm{Pt} / \mathrm{Pd}$ of 0.3 . The average $\mathrm{Pt} /$ $\mathrm{Pd}$ ratio for Eureka zone core intercepts is consistently around 0.5 (range 0.42-0.62), except for three westernmost drill holes, which average Pt/ Pd of 1.5 (Pure Nickel Inc., 2013). These outliers may represent a separate geological unit that was not recognized by Pure Nickel in the definition of the Eureka zone.

Determining the $\mathrm{Ni} / \mathrm{Cu}$ and $\mathrm{S} / \mathrm{Ni}$ ratios of sulfide mineralization in the study area is complicated by low concentrations of sulfide in many samples, an unknown contribution of hydrothermally remobilized sulfide, and significant concentrations of Ni-bearing cumulate olivine. Figure 24 attempts to get around these issues by highlighting samples with elevated $\mathrm{Pt}$, based on the assumption that this metal is closely associated with magmatic sulfide and is less susceptible than $\mathrm{S}, \mathrm{Cu}$, or $\mathrm{Pd}$ to hydrothermal remobilization.

Pt-enriched samples from the study area have $\mathrm{Ni} / \mathrm{Cu}$ ratios ranging from 0.4 to 3.4 , with most samples having $\mathrm{Ni} / \mathrm{Cu}$ between 1 and 2.5 (fig. 24). The $\mathrm{S} / \mathrm{Ni}$ ratios for these samples range from 0.2 to 5 .

$\mathrm{Ni} / \mathrm{Cu}$ ratios from Eureka zone drill intercepts range from 1.2 to 10.5 . Metallurgical work on a composite sample of the Eureka zone prospect

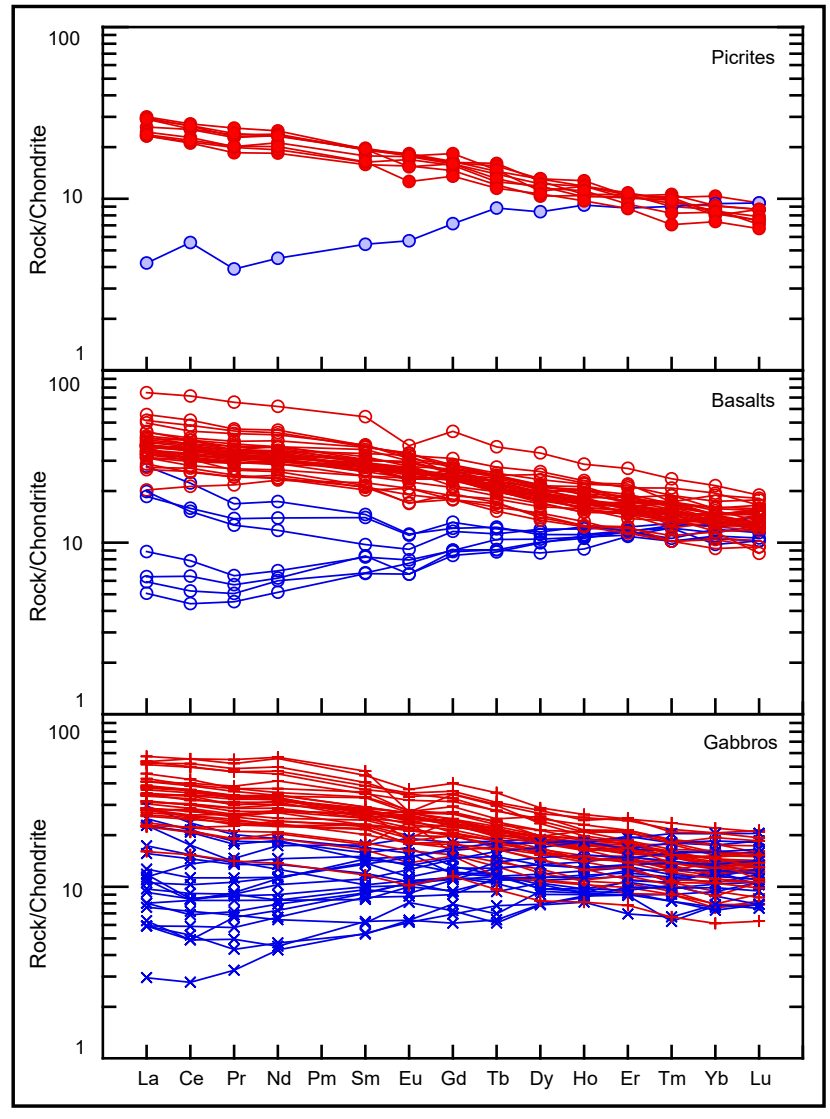

Figure 20. Chondrite-normalized REE plots after Sun and McDonough (1989) showing high-Ti series rocks in red and low-Ti series rocks in blue.

(2,800 ppm Ni; 1,200 ppm Cu; 0.77 percent S) indicates that 63 percent of the $\mathrm{Ni}$ occurs as $\mathrm{Ni}$ sulfide, with a further 12 percent present as a Fe-Ni alloy, which presumably formed during serpentinization (Pure Nickel Inc., 2014a). Calculating sulfide $\mathrm{Ni}$ based on this information indicates a $\mathrm{Ni} /$ $\mathrm{Cu}$ ratio of 1.5 (sulfide $\mathrm{Ni}$ only) to 2.0 (sulfide $\mathrm{Ni}$ plus alloy $\mathrm{Ni}$ ), which is in agreement with the values from Pt-mineralized samples (fig. 24A). Similarly, the S/Ni ratio calculated from Pure Nickel's metallurgical data is 3.3 or 4.4 , depending on whether alloy $\mathrm{Ni}$ is considered.

Metallurgical composite samples from the Wellgreen deposit (Makarenko and others, 2015) include a master composite $(3,700 \mathrm{ppm} \mathrm{Ni}$ in sulfide; 3,300 ppm $\mathrm{Cu} ; 2.53$ percent S) and a high-Ni composite (6,900 ppm Ni in sulfide; 5,200 ppm $\mathrm{Cu} ; 6.45$ percent $S$ ). Ni sulfide to $\mathrm{Cu}$ ratios for 


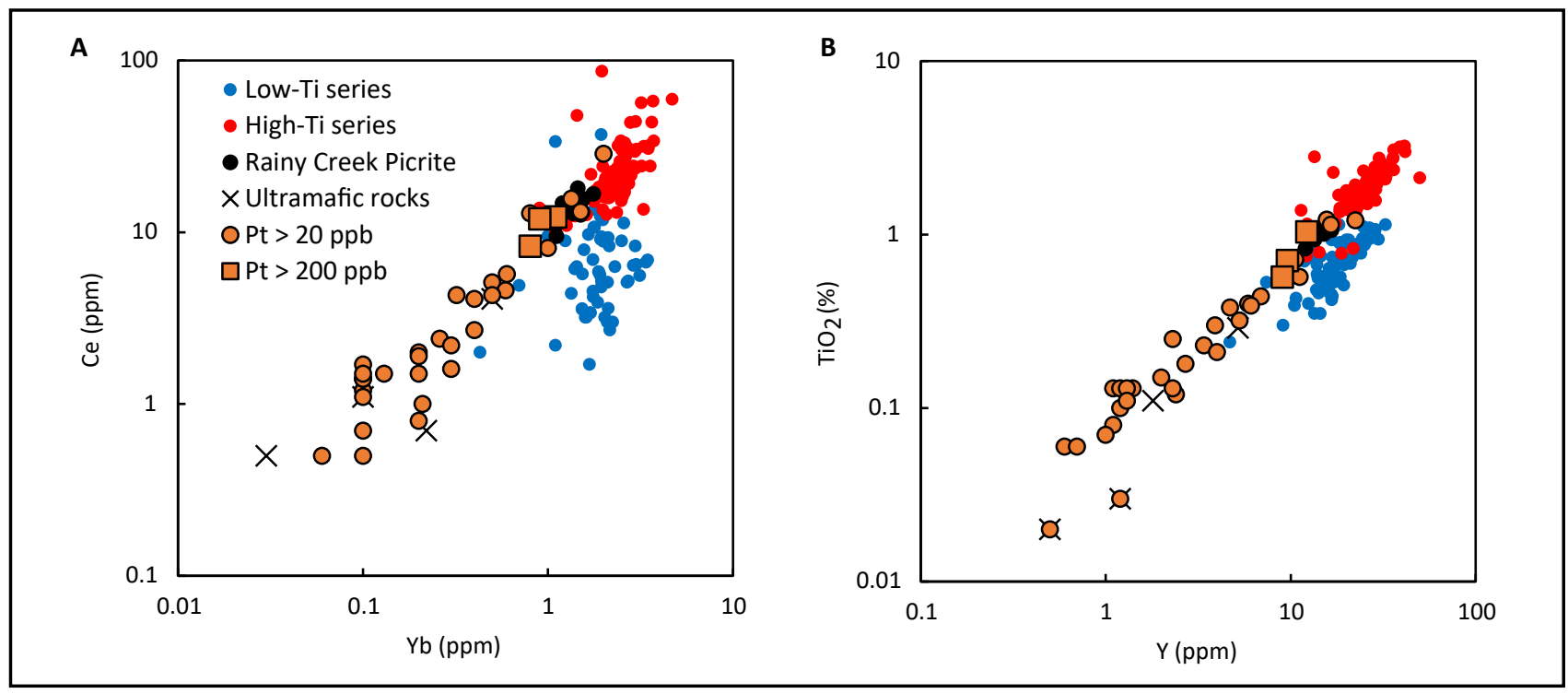

Figure 21. Bivariate scatterplots showing (A) rare earth elements Ce versus $\mathrm{Yb}$, and (B) TiO, versus $Y$ for the expanded DGGS datasets (Twelker and others, 2014a; Wypych and others, 2014; 2015) plus BLM (Bittenbender and others, 2007). Differing ratios (parallel trends) correspond to enriched (high-Ti and Rainy Creek) or depleted (low-Ti suite) REE trends (fig. 20).

these samples are 1.1 and 1.3 , respectively, similar to the ratios from our study area (fig. 24A). The $\mathrm{S}$ to $\mathrm{Ni}$ sulfide ratio for the master composite is 6.8 , while the high-Ni composite has S/Ni of 9.3 (fig. 24B).

\section{Mineral compositions}

Minerals crystallizing from magmas reflect the composition of the magma based on the Nernst distribution coefficient: $\mathrm{Kd}=$ (concentration of the element in the mineral) / (concentration of the element in the melt) (Rollinson, 1993). Subject to some possible complications (for example, re-equilibration during cooling), mineral compositions can be a useful tool for understanding melt compositions of cumulate rocks where the bulk composition no longer reflects the original magma. Further, the concentration of $\mathrm{Ni}$ in olivine will record $\mathrm{Ni}$ depletion in a melt where magmatic sulfide has separated from the silicate melt prior to olivine crystallization.

Olivine analyses for this study were collected using the University of Alaska Fairbanks JEOL JXA-8530F Electron Microprobe, with a beam current of $25 \mathrm{nA}$ at $20 \mathrm{KeV}$ and a beam diameter of 10 microns. Ca was measured using the PETL crystal, Fe and Ni were measured using LiFL crystals, and $\mathrm{Mg}$ and Si were measured using TAPL crystals. Count times were 2 minutes on peak and 2 minutes on background. As noted in tables 1 and 2 , some of the analyses used routines similar to those documented in Lande (2016).

\section{Discussion of geochemistry}

Lithogeochemical analyses show that rocks of picrite composition erupted in the Rainy Creek area as part of the Late Triassic Nikolai magmatic episode; these share many of the geochemical characteristics (Ti, HFSE ratios, REE patterns) of the high-Ti series magmas that comprise the majority of the Nikolai Greenstone. Most of the major- and trace-element patterns presented above suggest that the high-Ti basalts could be derived from a Rainy Creek picrite parental magma via fractional crystallization of olivine and chromite. The reverse cannot be true: textural evidence (fig. 6) indicates that the Rainy Creek picrites could not have been generated by addition of cumulate olivine to a high-Ti series basaltic parental magma because insufficient olivine phenocrysts were observed in rocks with clear volcanic textures. We make the assumption that olivine is too refractory to re-melt.

Clear differences in the $\mathrm{Th} / \mathrm{Zr}$ (fig. 19) ratios of high-Ti Nikolai and the Rainy Creek picrites 


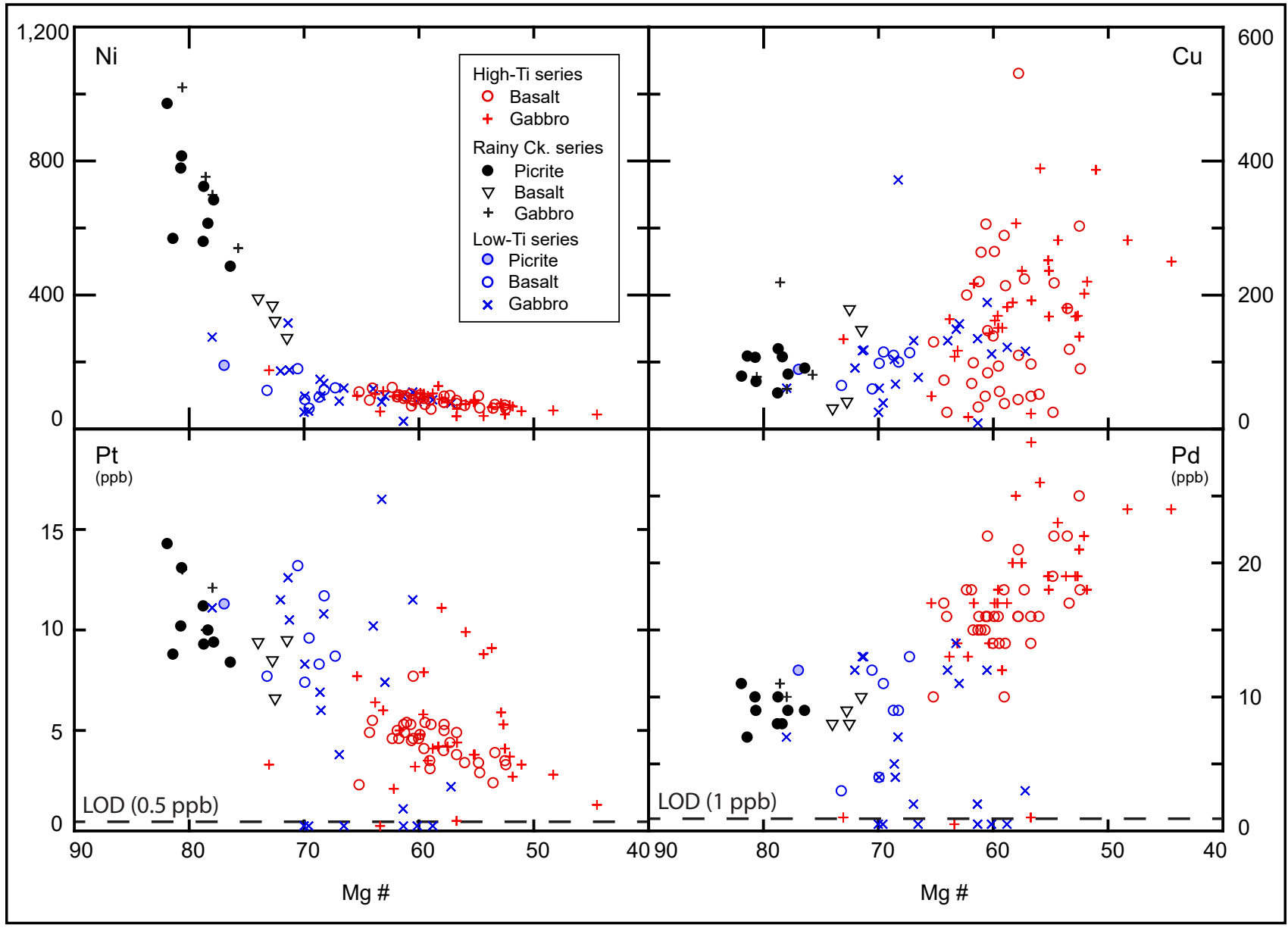

Figure 22. Variation of $\mathrm{Ni}, \mathrm{Cu}, \mathrm{Pt}$, and Pd with Mg \#. Samples with Pt and Pd values below their lower limit of detection (LOD) are plotted as one-half their detection limit.

challenge the interpretation that the two groups could be related by fractional crystallization. Pearce (2008) discusses Th (“Th-Nb proxy," normalized to $\mathrm{Yb}$; diagram not shown) as an indication of crustal assimilation, which could take the form of direct crustal assimilation, origin in a subduction-modified mantle wedge, or deep crustal recycling. All are possible; however, it is likely that Rainy Creek picrite melts, with their higher temperatures, would have an increased ability to assimilate local crust near their site of emplacement. It is less likely that the picrites are derived from a different area of the mantle, given other geochemical similarities with the high-Ti Nikolai series. The possibility remains that the high-Ti series magmas evolved from an initial picrite melt that did not reach the surface.
The demonstrated generation of a tholeiitic picrite melt is an important point for assessing the PGE mineral potential of the region. Such a melt composition indicates a relatively high degree of partial melting, roughly 30 percent (Jaques and Green, 1980; Arndt and others, 2005). A high degree of partial melting is necessary to dissolve residual sulfide liquid and mobilize chalcophile elements, including the PGEs during mantle partial melting (Arndt and others, 2005). Such a melt also incorporates more $\mathrm{Ni}$ through the melting of greater amounts of olivine.

For all magma series, $\mathrm{Ni}$ decreases with

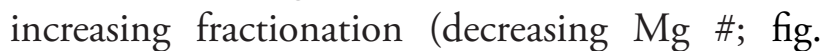
22); this reflects its lithophile behavior and high compatibility in olivine. 


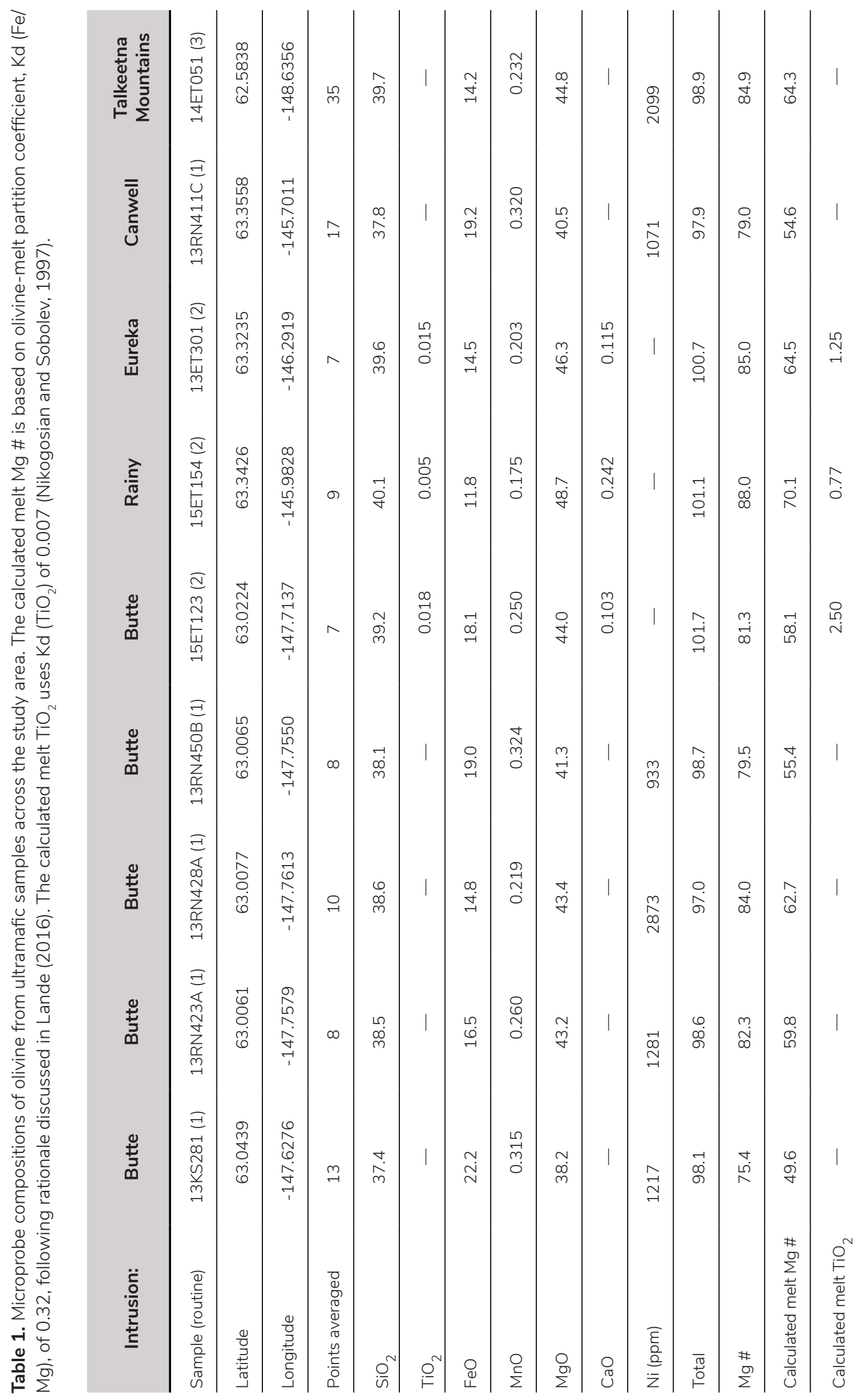




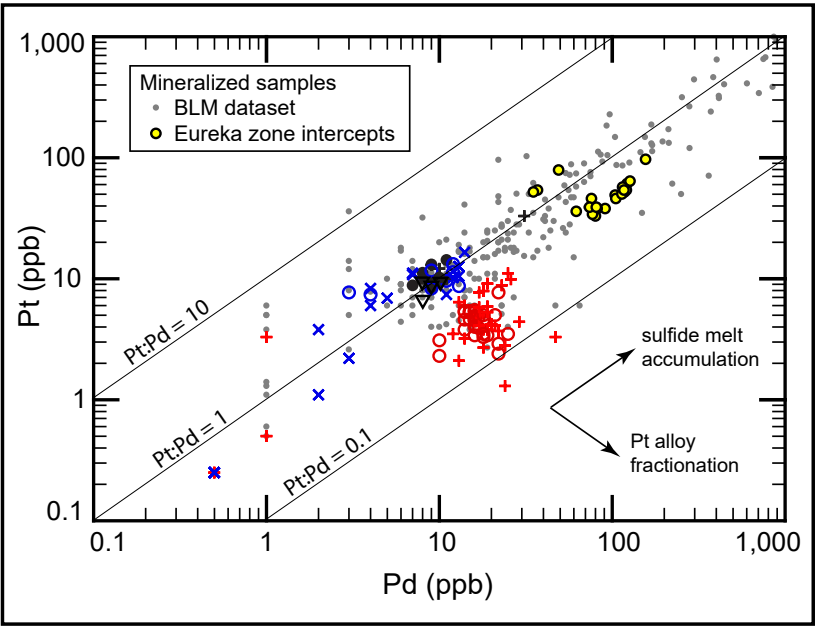

Figure 23. Bivariate plot showing Pt versus Pd (log scale). Additional data from BLM (Bittenbender and others, 2007) and Eureka zone drill core intercepts (Pure Nickel Inc., 2013) are plotted to illustrate PGE-enriched samples. See figure 22 for DGGS dataset legend.

The incompatible behavior of the chalcophile elements $\mathrm{Pd}$ and $\mathrm{Cu}$ (increasing with decreasing $\mathrm{Mg}$ \#; fig. 22) implies that, with some exceptions, these magmas did not fractionate a sulfide phase, liquid or solid. It is likely that both high- and low-Ti magma series evolved under sulfide-undersaturated conditions, an important precondition for development of magmatic $\mathrm{Ni}-\mathrm{Cu}-\mathrm{Co}-\mathrm{PGE}$ deposits. This incompatible trend is more apparent for $\mathrm{Pd}$ than for $\mathrm{Cu}$, which is more mobile and far more scattered. The trend is also more apparent for $\mathrm{Cu}$ versus $\mathrm{Mg}$ \# in high-Ti gabbros, which may be less subject to fluid flow, devitrification, and alteration than are glassy volcanic flows and flow breccias. The incompatible behavior of $\mathrm{Cu}$ contributes to the above-normal $\mathrm{Cu}$ content of the Nikolai Greenstone, especially the more evolved and voluminous high-Ti member. As discussed in the next section, this metal budget has apparently been remobilized by later plutonic or metamorphic thermal events to form epigenetic copper deposits at Kennecott (MacKevett and others, 1997), as well as Lichen in the northeastern Talkeetna Mountains, and likely Caribou Dome (Denali Copper) and Kathleen-Margaret in the Clearwater Mountains (Newberry and Twelker, 2016).
Some samples show strongly depleted Pt and Pd concentrations relative to the normal trends (fig. 22). Most depleted samples are depleted in both Pt and Pd, suggesting that sulfide melt separation, rather than $\mathrm{Pt}-\mathrm{Fe}$ alloy fractionation, is responsible for the depletion. All of the PGE-depleted samples in this study are gabbros, and most are of the low-Ti suite. The samples are geographically scattered throughout the study area. Because gabbro sills represent magma emplacement sites rather than conduits, and because these emplacement sites are widely scattered, we interpret our data as evidence for late-stage sulfide saturation and against early, large-scale sulfide saturation and fractionation. Ellis (2000) states that Pt and Pd are depleted by two orders of magnitude in portions of the basal volcanic flows overlying the Tangle (also known as Beta) ultramafic complex in the Tangle Lakes area. The base of the volcanic sequence in this area mapped as low-Ti series Nikolai Greenstone (unit Kn1; fig. 11), and this observation is apparently consistent with our data that indicate the majority of chalcophile depletion occurs in the early, low-Ti series magmas.

In contrast to $\mathrm{Pd}$ and $\mathrm{Cu}, \mathrm{Pt}$ behaves compatibly and decreases with increasing fractionation (fig. 22); this is particularly evident if the Rainy Creek picrites and the normal high-Ti series rocks, which have many chemical similarities, are considered together. The contrasting behavior of $\mathrm{Pt}$ and $\mathrm{Pd}$ during fractionation (fig. 22) and the consequent systematic changes in $\mathrm{Pt} / \mathrm{Pd}$ ratio with melt evolution may be explained by fractionation of a Pt-Fe alloy phase. These alloys, such as isoferroplatinum $\left(\mathrm{Pt}_{3} \mathrm{Fe}\right)$, strongly incorporate Pt over Pd. They are important Pt ore minerals in Ural-Alaska-type systems, where they co-occur with significant amounts of primary magnetite (Cox and Singer, 1986). Decoupling of $\mathrm{Pt}$ and Pd cannot be explained by fractionation of monosulfide solid solution (mss) or sulfide melt, as all of the Pd-group PGEs have similar partition coefficients for these phase relationships.

$\mathrm{Pt} / \mathrm{Pd}$ ratios are not expected to change during magmatic environment processes driven 


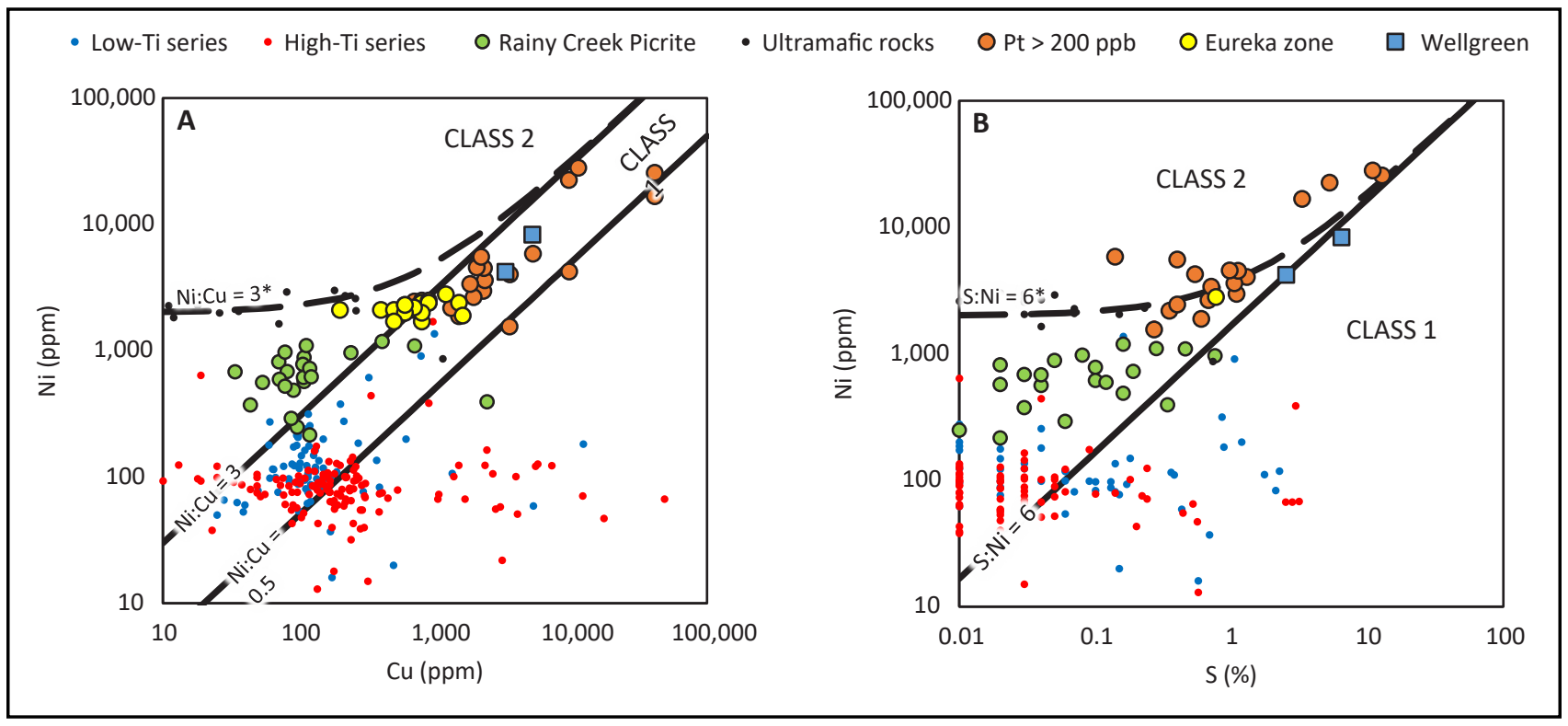

Figure 24. Bivariate plots of $(\mathbf{A})$ whole rock Ni versus $\mathrm{Cu}$, and (B) whole rock Ni versus S. Data are from DGGS (Twelker and others, 2014a; Wypych and others, 2014; 2015), BLM (Bittenbender and others, 2007), Pure Nickel Eureka zone drill intercepts (Pure Nickel Inc., 2013) and metallurgical composite (Pure Nickel Inc., 2014a), and Wellgreen metallurgical composites (Makarenko and others, 2015). Ratio lines correspond to divisions between Ni sulfide deposit classes in Barnes and Lightfoot (2005). Dashed lines marked "*” indicate the boundaries between class 1 and class 2 deposits if samples are assumed to contain 2,000 ppm Ni in olivine; samples must be above the dashed line to be considered unambiguously class 2 .

by gravitational concentration of immiscible sulfide liquid. Therefore, magmatic mineralization should retain the $\mathrm{Pt} / \mathrm{Pd}$ ratio of its originating intrusion. Figure 23 shows that the majority of mineralized samples from the expanded DGGSplus-BLM dataset have $\mathrm{Pt} / \mathrm{Pd}$ ratios near 1 , and that there are very few PGE-enriched samples with the lower $\mathrm{Pt} / \mathrm{Pd}$ ratio characteristic of the high-Ti series magmas. This is evidence that the majority of the mineralized samples are not related to the main, more evolved stage of the high-Ti Nikolai Greenstone. A possible exception is the Eureka zone of the Alpha (Fish Lake) ultramafic complex; in addition to it having a lower $\mathrm{Pt} / \mathrm{Pd}$ ratio of 0.5 (Pure Nickel Inc., 2013), work by Lande (2016) on the composition of clinopyroxenes indicates that the feldspathic peridotite hosting the Eureka zone was crystallized from a primitive basaltic, but not picritic, high-Ti magma.

Both Rainy Creek picrite and low-Ti series rocks have $\mathrm{Pt} / \mathrm{Pd}$ ratios of around 1 ; however, other trace elements seem to support a connection between mineralization and Rainy Creek magmas. $\mathrm{REE}$, including $\mathrm{Ce}$ and $\mathrm{Yb}$ (fig. 21A), are negligibly (but similarly) compatible in olivine, and their ratios are not significantly affected by olivine cumulate processes. The same can be said for $\mathrm{TiO}_{2}$ and $\mathrm{Y}$ (fig. 21B). Measurable amounts of REE and Y occur in many cumulate samples that crystallized some fraction of melt; these rocks retain REE and Ti/Y ratios similar to the basalts, picrites, or gabbros illustrated in figure 20. Samples with elevated PGE (fig. 21) retain the REE and Ti/Y ratios of Rainy Creek picrites and high-Ti series Nikolai Greenstone.

Clinopyroxene composition analyses by Lande (2016) indicate that the upper sills of the Alpha ultramafic complex crystallized from low-Ti melts, while the basal sills may have crystallized from a melt with an intermediate $\mathrm{Ti}$ content, possibly a hybrid between the two magma series. Compositional zoning and evidence of disequilibrium textures support this hypothesis (Lande, 2016). Whole rock REE, Ti, and Y data in Lande (2016) indicate that, like other samples in our 
Table 2. Pyroxene compositions from several ultramafic samples across the study area. The calculated melt Mg \# is based on clinopyroxene-melt partition coefficient, $\mathrm{Kd}(\mathrm{Fe} / \mathrm{Mg})$, of 0.20 , and the calculated melt $\mathrm{TiO}_{2}$ uses $\mathrm{Kd}\left(\mathrm{TiO}_{2}\right)$ of $0.45(\mathrm{Hauri}$ and others, 1994), following rationale discussed in Lande (2016). All analyses use the microprobe routine for clinopyroxene documented in Lande (2016).

\begin{tabular}{|c|c|c|c|c|c|c|}
\hline Intrusion: & Butte & Butte & Butte & Butte & Eureka & Canwell \\
\hline Sample & 13RN428A & 13RN450B & $\begin{array}{l}\text { 15ET123 } \\
\text { (срx) }\end{array}$ & $\begin{array}{l}\text { 15ET123 } \\
\text { (opx) }\end{array}$ & 13ЕТ301 & 13RN411C \\
\hline Latitude & 63.0077 & 63.0065 & 63.0224 & 63.0224 & 63.3235 & 63.3558 \\
\hline Longitude & -147.7613 & -147.7550 & -147.7137 & -147.7137 & -146.2919 & -145.7011 \\
\hline Points & 8 & 8 & 4 & 3 & 12 & 12 \\
\hline $\mathrm{SiO}_{2}$ & 55.1 & 52.2 & 52.9 & 52.6 & 51.9 & 52.6 \\
\hline $\mathrm{TiO}_{2}$ & 0.440 & 0.359 & 0.466 & 0.412 & 0.687 & 0.446 \\
\hline $\mathrm{Al}_{2} \mathrm{O}_{3}$ & 1.69 & 2.99 & 1.68 & 1.115 & 3.02 & 2.45 \\
\hline $\mathrm{FeO}$ & 4.80 & 4.45 & 4.97 & 12.0 & 4.83 & 4.69 \\
\hline $\mathrm{MnO}$ & 0.173 & 0.114 & 0.147 & 0.315 & 0.138 & 0.144 \\
\hline $\mathrm{MgO}$ & 18.0 & 17.1 & 18.0 & 30.3 & 17.8 & 17.2 \\
\hline $\mathrm{Na}_{2} \mathrm{O}$ & 0.256 & 0.209 & 0.266 & 0.036 & 0.411 & 0.339 \\
\hline $\mathrm{CaO}$ & 21.3 & 22.0 & 20.9 & 1.495 & 20.1 & 21.1 \\
\hline $\mathrm{Cr}_{2} \mathrm{O}_{3}$ & 0.48 & 1.01 & 0.81 & 0.222 & 0.96 & 0.91 \\
\hline Total & 102.2 & 100.4 & 100.2 & 98.5 & 99.9 & 99.9 \\
\hline Mg \# & 87.1 & 87.2 & 86.6 & 81.8 & 86.8 & 86.8 \\
\hline $\begin{array}{l}\text { Calculated } \\
\text { melt Mg \# }\end{array}$ & 57.5 & 57.8 & 56.4 & - & 56.7 & 56.7 \\
\hline 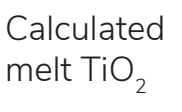 & 0.98 & 0.80 & 1.03 & - & 1.53 & 0.99 \\
\hline
\end{tabular}

study, the cumulate ultramafic rocks have the Ce/ $\mathrm{Yb}$ and $\mathrm{Ti} / \mathrm{Y}$ ratios of the high-Ti series magmas (fig. 21). These data seem to suggest that even the sills with low-Ti clinopyroxene experienced a flux of high-Ti magma.

\section{Summary of magmatic system}

The Late Triassic Nikolai Greenstone magmatic system can be subdivided into high-Ti,
low-Ti, and a primitive Rainy Creek picrite series. In most respects, the Rainy Creek picrite appears to be a primitive endmember of the high-Ti series.

Early, low-Ti series melts (fig. 25A) originated by partial melting of a depleted-mantle source to form tholeiitic parental magmas of primitive basalt to picritic composition. The melt experienced crustal contamination and evolved by fractional crystal- 
lization of olivine, including generation of olivine and clinopyroxene cumulates at the Alpha, Rainy, and other ultramafic complexes. Evolution largely occurred under sulfide-undersaturated conditions, but immiscible sulfide melts formed in some locations, and their separation from the silicate melt resulted in local depletion of chalcophile elements.

Relatively high-degree partial melting of an enriched-mantle source resulted in the generation of a Ni-rich tholeiitic picrite melt, the parental melt to both the Rainy Creek picrite and the high-Ti series (fig. 25B). A portion of this melt reached the surface with little fractionation, was contaminated by $\mathrm{Th}$, and erupted as the Rainy Creek picrite. Another portion of this melt invaded the conduits of the low-Ti series magmas, inheriting cumulate olivine and sulfide precipitated by the preceding magmas. High-Ti magmas hybridized with residual low-Ti melts, formed high-Ti series cumulate intrusions, and became the residual intercumulus melt in intrusions where most olivine crystallized from low-Ti magmas. These melts also generated olivine and clinopyroxene cumulates. Locally, the melt reached sulfide saturation and separated an immiscible sulfide melt, leading to PGE-depleted high-Ti series gabbros and ultramafic rocks.

The evolved subset of the high-Ti series melt fractionated olivine and possibly a platinum alloy "at depth," in magma chambers that were not sampled in this study. Melt evolution, which occurred under sulfide-undersaturated conditions, increased the concentrations of $\mathrm{Cu}$ and $\mathrm{Pd}$. This melt erupted as the thick, regionally extensive upper member of the Nikolai Greenstone (fig. 25B).

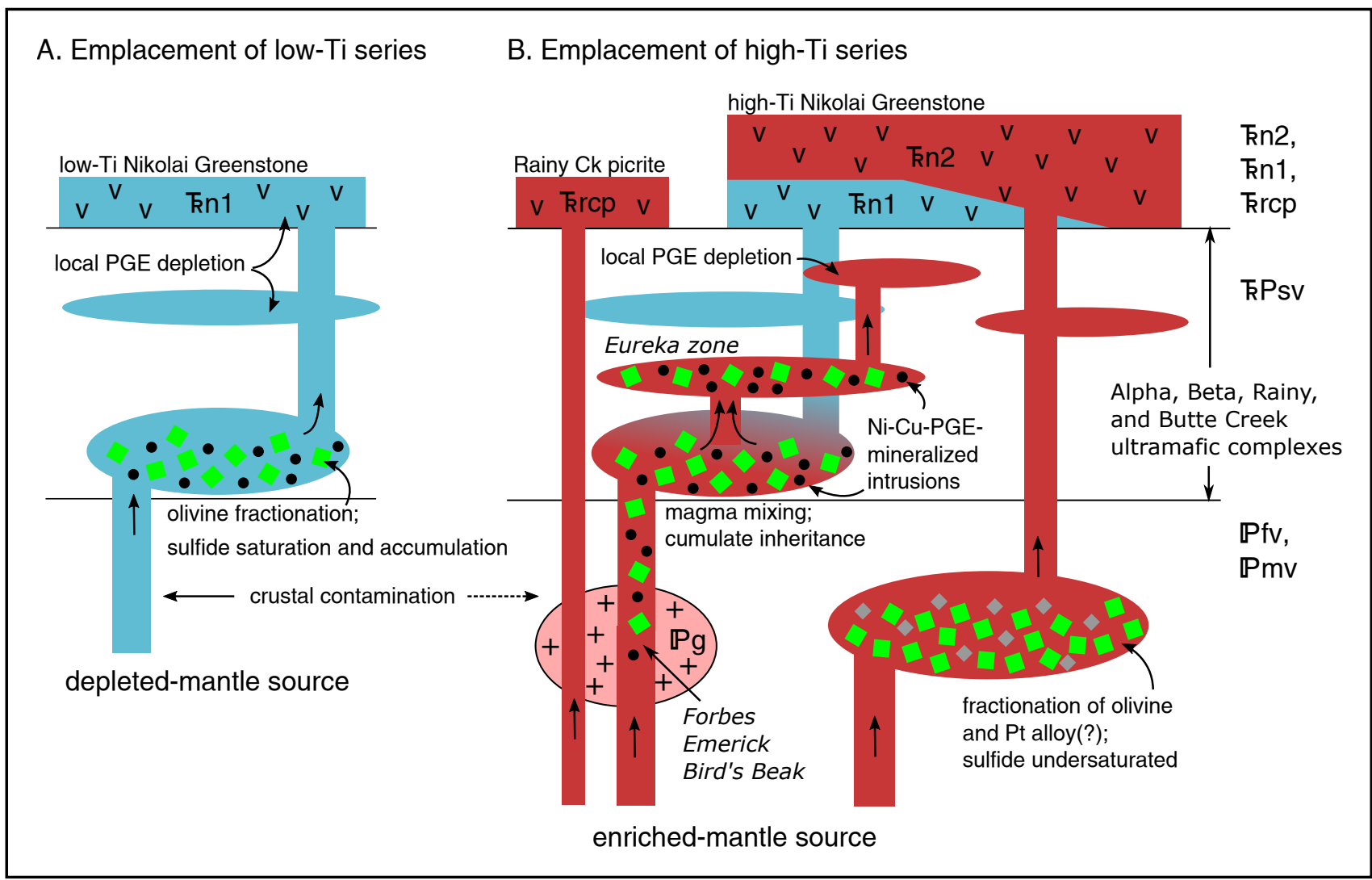

Figure 25. Schematic diagram illustrating our understanding of the Late Triassic Nikolai Greenstone magmatic system and associated $\mathrm{Ni}$-Cu-Co-PGE mineralization and volcanic rocks. Emplacement of both low-Ti series (A) and high-Ti series (B) magmas occurred within a time interval as short as 2 Ma (Greene and others, 2010). Green squares represent cumulate olivine and lesser clinopyroxene; black dots represent separated magmatic sulfide; gray squares represent cumulate Pt alloy. See figure 3 for geological unit abbreviations. 


\section{Geologic model for Ni-Cu-Co-PGE mineralization}

While most previous workers (Ellis, 2000; Hulbert and Stone, 2006) cite Norilsk-type Ni-CuCo-PGE sulfide deposit models when describing the style of mineralization in our study area, the Alpha (or Fish Lake) ultramafic complex and its Eureka zone (occurrence 12, appendix) have also been investigated as a possible reef-style PGE target (for example, Stillwater, Bushveld; Cox and Singer, 1986; model 2b). This is owing to the large size of the intrusion (approximately $33 \mathrm{~km}$ long and $3 \mathrm{~km}$ thick), magmatic layering visible in the field, and the position of the PGE-mineralized Eureka zone well above the base of the intrusion (Findlay, 2013). However, detailed mapping and mineral composition studies by Lande (2016) indicate that the Eureka zone mineralization is hosted as disseminated magmatic sulfides in a roughly 250 -m-thick feldspathic peridotite intrusion emplaced into the larger, multiphase complex near the end of its formation.

Further, the composition of sulfide in reeftype PGE deposits typically contains much higher values of PGEs than are found in "basal sulfide"type Ni-Cu-Co-PGE systems. Figure 26 shows the values of $\mathrm{Pd}$ and $\mathrm{Cu}$ from mineralized rocks in the study area and the Eureka zone in comparison to those from the major primary magmatic PGE-deposit types; these values are much too low for reeftype mineralization and are most closely similar to gabbro-hosted Ni-Cu deposits (Cawthorn and others, 2005).

Magmatic Ni-Cu-Co-PGE sulfide deposits may be classified by their $\mathrm{Ni} / \mathrm{Cu}$ ratio, $\mathrm{S} / \mathrm{Ni}$ ratio, and host lithology. Class 1 deposits have $\mathrm{Ni} / \mathrm{Cu}$ ratios in the range of $0.8-2.5$, while class 2 have $\mathrm{Ni} / \mathrm{Cu}$ ratios greater than 3 . These ratios reflect the composition of the silicate melt from which the sulfide liquid separated; class 1 deposits are associated with predominantly gabbroic rocks (gabbronorite to troctolite), with minor peridotites and pyroxenites, while class 2 deposits are associated with ultramafic rocks, including komatiites and picrites. Ratios of $\mathrm{S} / \mathrm{Ni}$ are typically greater than 6 for class 1 deposits, and less than 6 for class 2 deposits (Barnes and Lightfoot, 2005).

$\mathrm{Ni} / \mathrm{Cu}$ ratios in the range of $0.5-2.5$ suggest comparison to class $1 \mathrm{Ni}$-Cu-Co-PGE depositsthat is, those related to gabbroic magmas-even where the host rocks are cumulate peridotites, as at the Eureka zone (fig. 24A). The $\mathrm{Ni} / \mathrm{Cu}$ ratio of Rainy Creek picrites is significantly higher, ranging from 1.5 to 12.3 and averaging 7.5 . Therefore, it is unlikely that the magmatic sulfide mineralization observed separated directly from unfractionated Rainy Creek picrite magma. Sulfide melt could achieve a $\mathrm{Ni} / \mathrm{Cu}$ ratio less than 3 if it separated from a picritic parental melt after the crystallization of a significant amount of olivine; however, such fractionation is inconsistent with the $\mathrm{S} / \mathrm{Ni}$ ratios observed.

Values for $\mathrm{S} / \mathrm{Ni}$ in mineralized samples straddle the boundary between class 1 (gabbro-related) and class 2 deposits associated with picrite or komatiite host rocks (fig. 24B). This result could be consistent with an association between $\mathrm{Ni}-\mathrm{Cu}$ Co-PGE mineralization and unfractionated Rainy Creek picrite magma. Most mineralized samples come from north of the Rainy Creek thrust (RCT) and have the same $\mathrm{Ce} / \mathrm{Yb}$ (fig. 21) and $\mathrm{Pt} / \mathrm{Pd}$ ratios (fig. 23) as the Rainy Creek picrites. However, this conclusion is at odds with the conclusion suggested by class $1 \mathrm{Ni} / \mathrm{Cu}$ ratios.

One possible means of decreasing the $\mathrm{S} / \mathrm{Ni}$ ratio without change to the $\mathrm{Ni} / \mathrm{Cu}$ ratio is fractionation of iron-rich mss. Another possible explanation for low $\mathrm{S} / \mathrm{Ni}$ values in our eastern Alaska Range study area is that the system here has less access to country-rock sulfide than do other systems. A critical component cited for the genesis of many large Ni-sulfide deposits is the assimilation of country-rock sulfur in the form of evaporites or pyritic sediments; this changes the melt composition and causes separation of an immiscible sulfide melt (Arndt and others, 2005). At Norilsk, sulfur isotope $\left(\delta^{34} S\right)$ values of the ore approach those of country rock's evaporites, 
evidence that "a large proportion" of the sulfur in the ore was derived from the country rock (Arndt, 2011). However, in Yukon's Kluane Range, sulfur isotopes and S/Se ratios indicate that gabbro-hosted massive sulfide ores at Wellgreen experienced only 2.5 to 8.3 percent crustal contamination (Hulbert, 1997). Such a small amount of country-rock sulfide would not be enough to explain the difference in $\mathrm{S} / \mathrm{Ni}$ between our study area and Wellgreen: the $\mathrm{S} / \mathrm{Ni}$ ratio of Wellgreen metallurgical composites (Makarenko and others, 2015) is approximately double that of our central Alaska samples. Furthermore, sulfide mineralization associated with Kluane Range intrusions showing a higher degree of crustal contamination (up to 35 percent) is barren of $\mathrm{Ni}$, $\mathrm{Cu}$, and PGE (Hulbert, 1997). Our results for the eastern Alaska Range do not suggest insufficient country-rock sulfide.

\section{$\mathrm{Ni}$-Cu-Co-PGE potential and applications to exploration}

High-degree partial melting of the mantle is necessary to generate magmas that are fertile for formation of Ni-Cu-Co-PGE deposits (Arndt and others, 2005). These magmas, tholeiitic picrites, occur in the study area and were erupted in several locations (fig. 27). One clear locus of primitive volcanism is the Rainy Creek area, where tholeiitic picrites dominate the Late Triassic volcanic section and "normal" volcanic rocks of the Nikolai Greenstone section are absent. Low-Ti picrites occur sporadically across the study area but have been less studied.

Potential hosts of magmatic Ni-Cu-Co-PGE sulfide mineralization are mafic-ultramafic intrusions, and these occur widely across the study area, as shown in figure 28. The known Ni-Cu-Co-PGE mineralization in the study area is empirically associated with olivine \pm clinopyroxene cumulate rocks; the distribution of these rocks (fig. 28) is heavily biased towards the Rainy Creek-Eureka CreekTangle Lakes area, as well as the Butte Creek area. These cumulates apparently reflect the fractionation and comingling of primitive magmas of both the high- and low-Ti series.

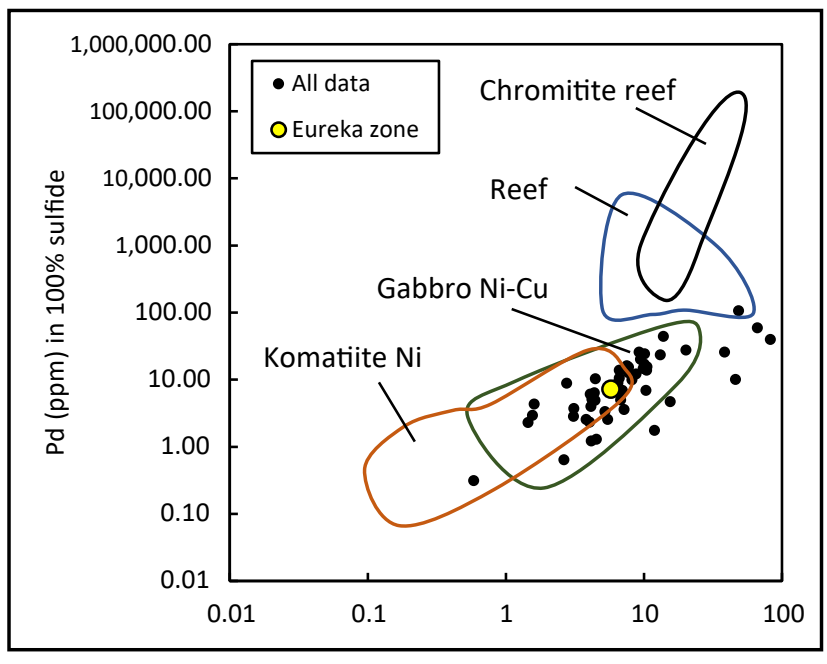

Figure 26. Plot of $\mathrm{Pd}$ and $\mathrm{Cu}$ values (normalized to 100 percent sulfide) in comparison to typical magmatic sulfide compositions of different PGE-deposit types after figure 14 of Cawthorn and others (2005). Only values of S greater than 0.25 percent and values of Pt greater than $0.02 \mathrm{ppm}$ are shown. Data are the DGGS and BLM whole rock dataset; Eureka zone data is from a composite metallurgical sample (Pure Nickel Inc., 2014a). Sulfide is calculated as 37 percent $S$ based on data in Arndt and others (2005).

In order to form a magmatic sulfide deposit, the ascending magma must reach sulfide saturation and form an immiscible sulfide melt. In order to achieve economic grades, this melt must interact with large volumes of silicate melt, which consequently becomes depleted in chalcophile elements. Figure 29 shows the locations where chalcophile elements Pt and Pd are strongly depleted from the silicate melt; this effect is seen to cluster in the Rainy Creek and Butte Creek areas, and Ellis (2000) reports strong PGE depletion in the volcanics near Tangle Lakes.

If sulfide saturation occurs after the crystallization of olivine, the resulting sulfide melt formed will be Ni-poor. However, figure $24 \mathrm{~B}$ shows that sulfiderich samples are in fact relatively $\mathrm{Ni}$-rich. Backscatter-electron (BSE) imagery of a spherical Fe-Ni sulfide melt inclusion within olivine provides direct evidence that sulfide saturation occurred prior to olivine crystallization at the Butte Creek ultramafic complex (occurrence 11, appendix; fig. A8). 
Based on rock sampling (Bittenbender and others, 2007) and exploration drill results (Pure Nickle Inc., 2013) to date, we suggest that rocks with the geochemical signature of the primitive Rainy Creek picrite or other very primitive high-Ti series magmas have the highest prospectivity for magmatic $\mathrm{Ni}-\mathrm{Cu}-\mathrm{Co}-\mathrm{PGE}$ sulfide mineralization. These may include rocks where magmatic sulfide, olivine, and clinopyroxene were partly inherited from earlier, low-Ti series magmas sharing the same conduits. The evolved, high-Ti magmas appear to have less prospectivity.

As discussed above, the evolved, high-Ti series magmas have significantly different characteristic $\mathrm{Pt} / \mathrm{Pd}$ ratios, and this observation can be applied to geochemical exploration. Stream-sediment geochemistry (Werdon and others, 2014; Twelker and others, 2014) indicates anomalous PGE values in many drainages across the central part of the study area (fig. 30). The Pt/Pd ratio of PGE-anomalous samples is bimodal, one population having $\mathrm{Pt} / \mathrm{Pd}$ greater than 1 , and a second group having $\mathrm{Pt} / \mathrm{Pd}$ of 0.3 to 0.5 (fig. 30 inset). These patterns parallel those of rock samples shown in figure 23 .

$\mathrm{Pd}$-anomalous stream sediment samples $(\mathrm{Pt} /$ Pd less than 1) are spatially associated with areas of evolved, high-Ti series Nikolai Greenstone. Rocks in these areas and with these $\mathrm{Pt} / \mathrm{Pd}$ ratios are not known to have significant PGE enrichment (with the possible exception of the Eureka zone), but they may be associated with basalt- or sediment-hosted copper mineralization such as at the Caribou Dome and Lichen prospects. $\mathrm{Pd}$ and $\mathrm{Cu}$ are both enriched with progressive fractionation of high-Ti

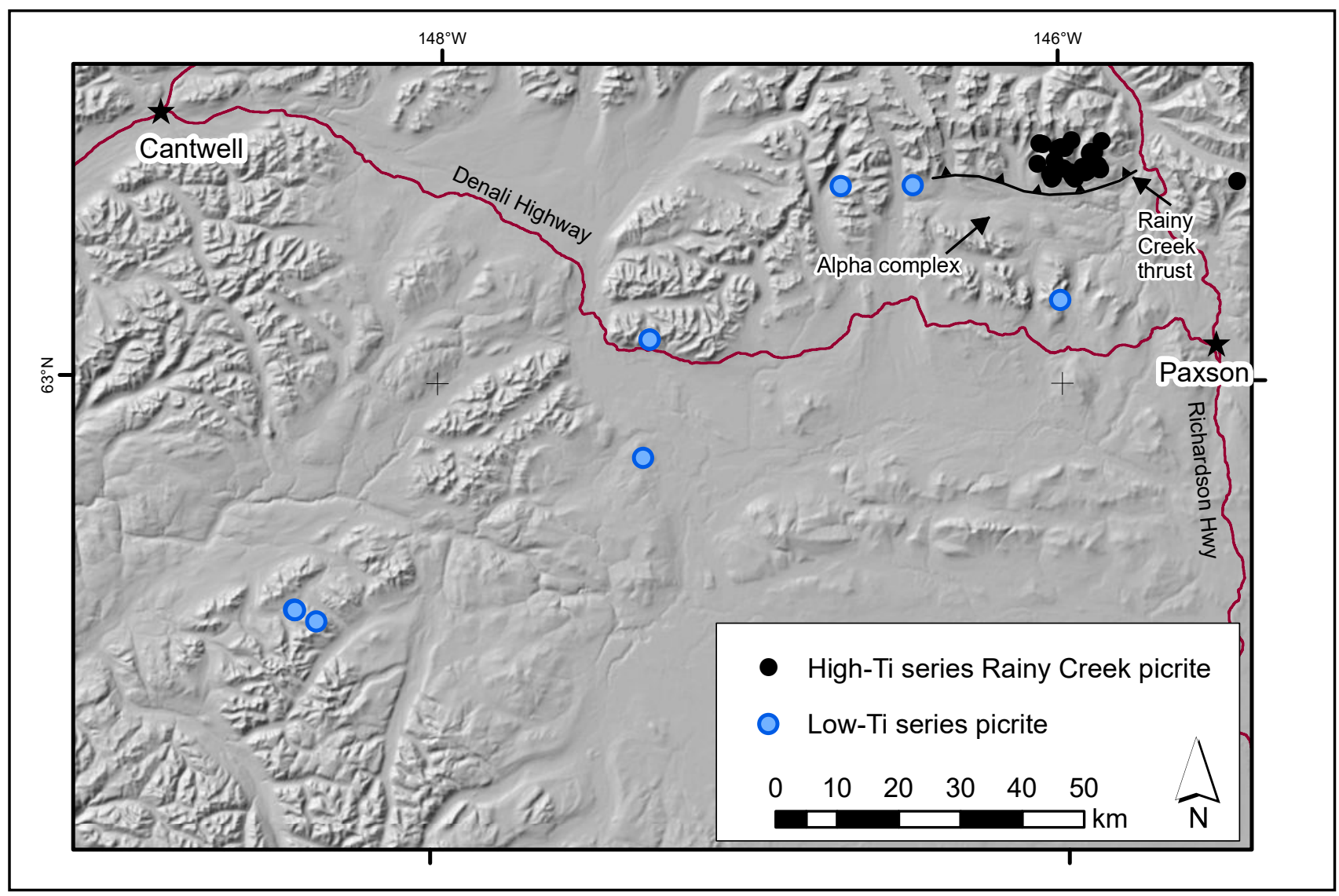

Figure 27. Distribution of Late Triassic picrite volcanic rock samples from across the study area, including data from USGS (Granitto and others, 2013), BLM (Bittenbender and others, 2007), Greene and others (2008) as well as DGGS (Twelker and others, 2014a; Wypych and others, 2014, 2015). 
series magmas (fig. 22). Pt/Pd-anomalous samples (Pt/Pd greater than 1) occur in the Rainy Creek, Eureka Creek, and Butte Creek drainages. Based on the $\mathrm{Pt} / \mathrm{Pd}$ ratios, these stream sediments are likely sourced from Rainy Creek picrite, primitive high-Ti series magmas, or low-Ti series magmas known to carry elevated values of $\mathrm{Ni}, \mathrm{Cu}, \mathrm{Co}$, and PGE in these areas.

In the Eureka Creek-Rainy Creek-Canwell Glacier area (fig. 31), mineralized samples north of the Rainy Creek thrust tend to have $\mathrm{Pt} / \mathrm{Pd}$ greater than 0.8 , indicating more primitive magmas. This area corresponds to the Rainy Creek block in figure 13. South of the Rainy Creek thrust (Amphitheater Mountains block in fig. 13), most mineralized samples, including the Eureka zone drill intercepts, have lower $\mathrm{Pt} / \mathrm{Pd}$ ratios. Note that these ratios are not as low as those of the unmineralized, signifi- cantly more evolved high-Ti magmas (see figs. 23 and 30).

The highest Ni-Cu-Co-PGE grades sampled by BLM and DGGS are found north of the Rainy Creek thrust in the Canwell Glacier and Bird's Beak areas (fig. 31). Mafic-ultramafic intrusions in these areas intrude into Pennsylvanian granitic rocks that represent the plutonic roots of the Skolai arc, necessarily a deeper level than the emplacement sites of the majority of sill-form intrusions in the study area. These more deeply emplaced intrusions are more likely candidates for highthroughput magmatic conduits, whereas the shallowly emplaced sill-form intrusions are more likely to be magmatic emplacement sites. It is not clear why they carry higher grades, but the relationship between stratigraphic depth of emplacement and $\mathrm{Ni}-\mathrm{Cu}-\mathrm{Co}-\mathrm{PGE}$ tenor may be significant.

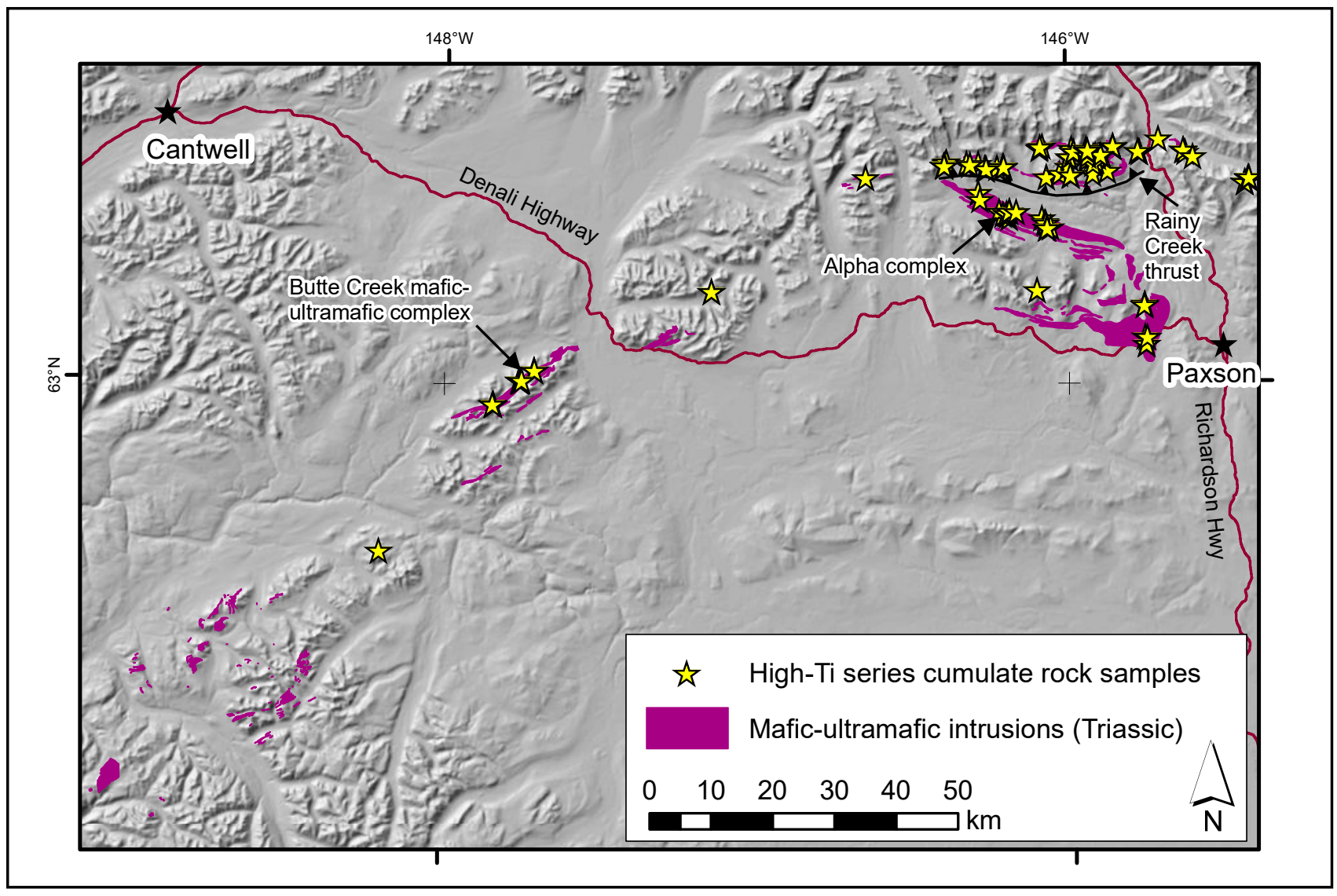

Figure 28. Distribution of Late Triassic mafic-ultramafic intrusions (Twelker and others, 2015a, 2020; Werdon and others, 2002) and high-Ti series olivine \pm clinopyroxene cumulate rock samples from datasets of DGGS (Twelker and others, 2014a; Wypych and others, 2014; 2015), BLM (Bittenbender and others, 2007), and USGS (Granitto and others, 2013). 


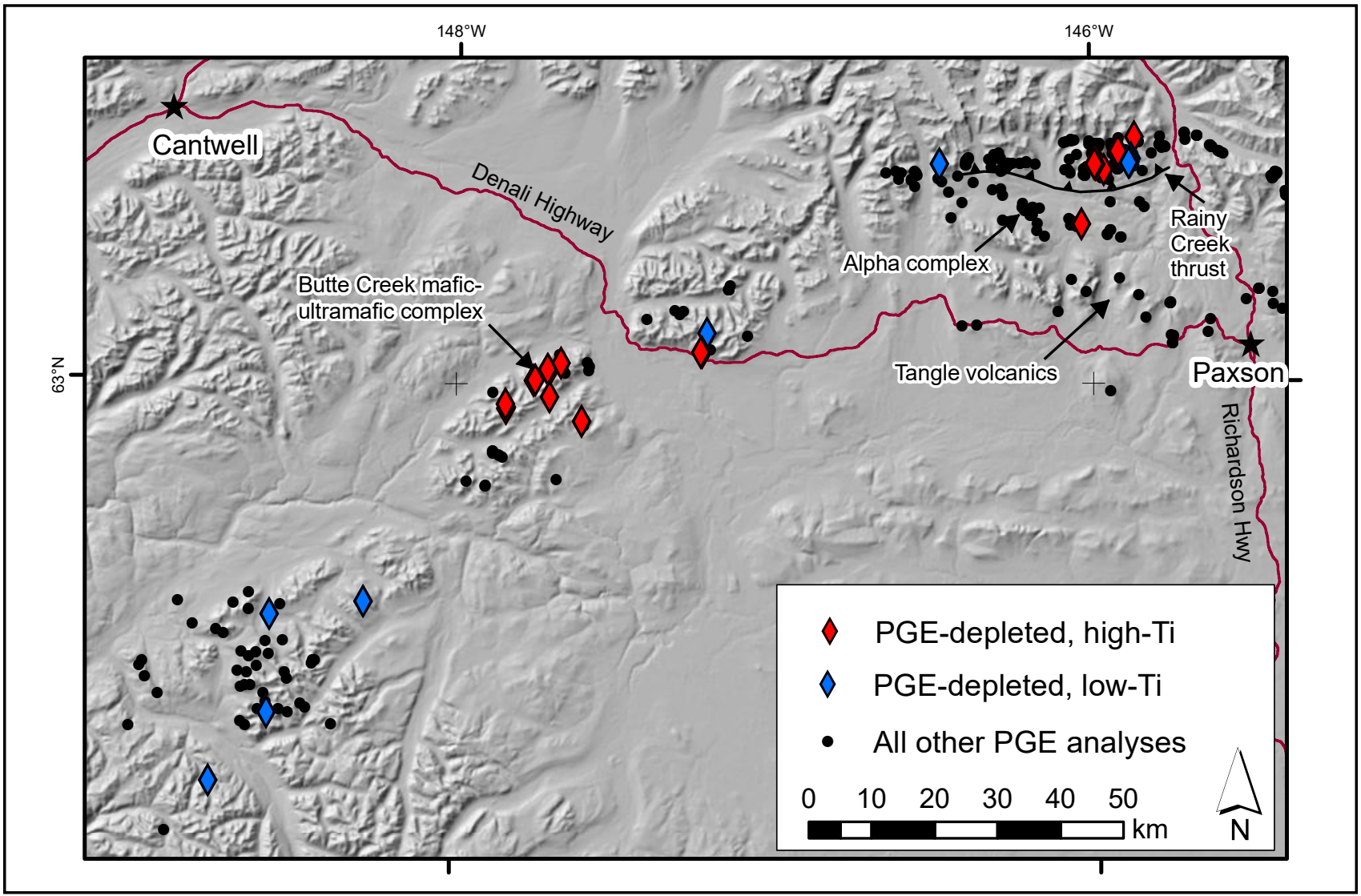

Figure 29. Samples depleted in Pt and Pd in the DGGS and BLM whole rock dataset. All samples are gabbros or cumulate ultramafic rocks. Ellis (2000) reports extreme PGE depletion at the base (low-Ti member) of the Nikolai Greenstone in the Tangle Lakes area (“Tangle volcanics”; labeled on map).

\section{METALLOGENESIS OF OTHER DEPOSIT TYPES}

\section{Basalt- and sediment-hosted copper mineralization}

Numerous $\mathrm{Cu}$-rich mineral occurrences are known in and near the Late Triassic Nikolai Greenstone in central Alaska (Ellis and others, 2004), and previous workers (MacKevett and others, 1997) have speculated about their genetic origins and relationship to the Nikolai Greenstone. Based on our major- and trace-element datasets (ICP-MS and XRF) and petrographic studies, we support the hypothesis that most of these prospects are derived from metals extracted from the Nikolai Greenstone by hot water; others are instead related to mid-Cretaceous plutonic fluids.
Elemental abundances of the stratigraphically upper, high-Ti series Nikolai Greenstone suggest it evolved in a sulfide-undersaturated environment and became unusually enriched in $\mathrm{Cu}$ (averaging \pm $130 \mathrm{ppm} \mathrm{Cu}$; fig. 22) relative to average mid-ocean ridge basalt (74 ppm Cu; Gale and others, 2013) and to the low-Ti series Nikolai Greenstone (averaging $79 \mathrm{ppm} \mathrm{Cu}$ ). However, concentrations of many elements (including $\mathrm{Cu}$ ) and elemental oxides vary widely (for example, $\mathrm{Na}_{2} \mathrm{O}=0.07$ to 5.9 weight percent), and some are strongly depleted (for example, $\mathrm{Ba}$ and $\mathrm{Sr}$, with half the concentrations of average basalt; fig. 32A). Petrographically, the Nikolai Greenstone ubiquitously contains abundant chlorite, albite, and sericite. Because much of the upper Nikolai Greenstone in central Alaska was deposited subaerially, these mineralogical and 


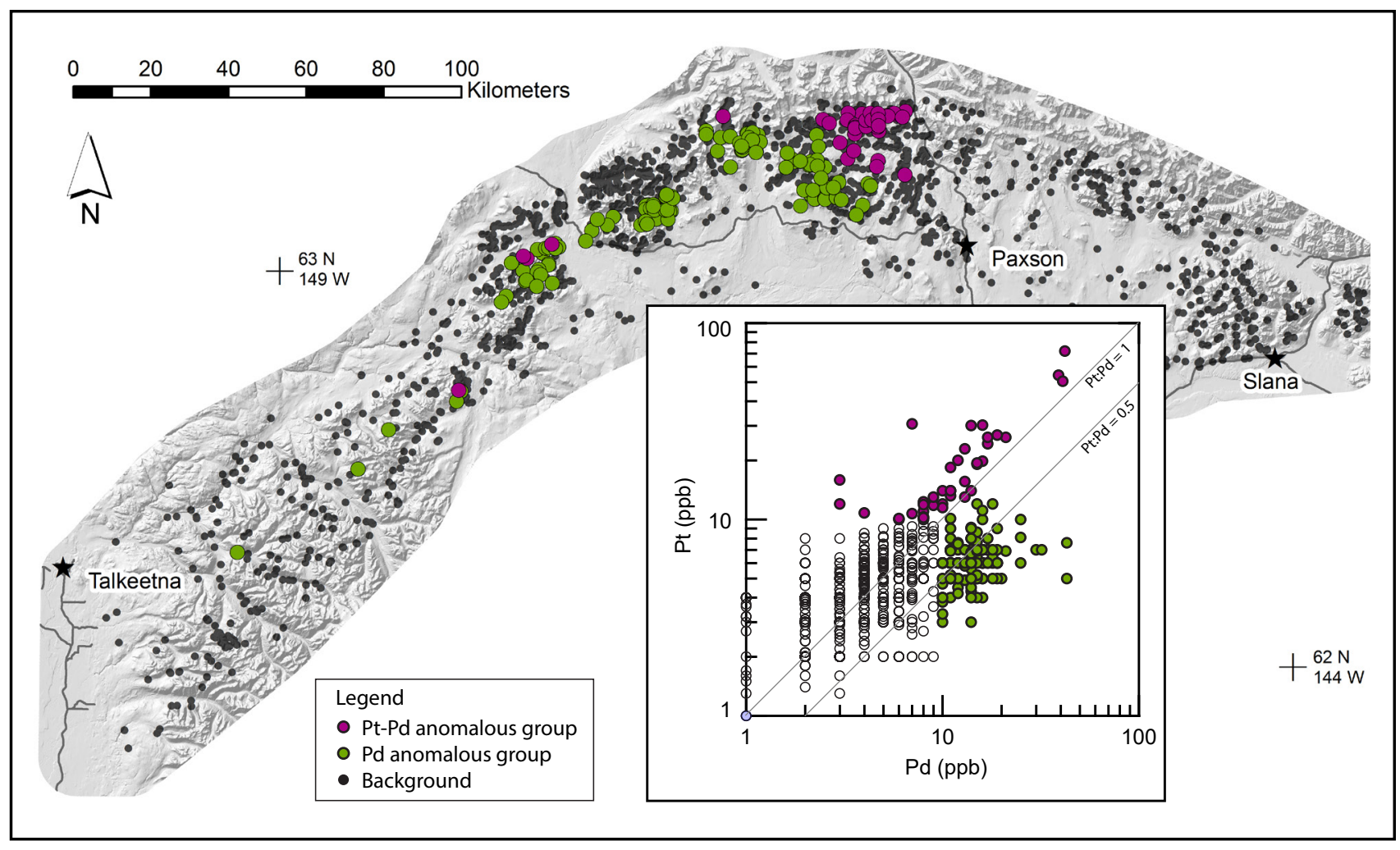

Figure 30. Map and bivariate plot showing the distribution of stream-sediment samples with greater than $10 \mathrm{ppb} \mathrm{Pt}$ or Pd, and Pt/Pd ratio of 1 or greater (purple) or Pt/Pd ratio of less than 1 (green). Samples with Pt/Pd less than 1 are likely sourced from the evolved subset of high-Ti series rocks, such as the upper member of the Nikolai Greenstone (unit kn2). Samples with Pt/Pd greater than 1 are likely sourced from Rainy Creek picrite or similar primitive high-Ti rocks, from low-Ti series rocks, or a combination of these. A Pt/Pd ratio of about 1 is typical of known PGE-bearing prospects in the study area (see fig. 23). Stream sediment data are from Werdon and others (2014).

compositional changes reflect post-eruption fluid movement at greenschist-facies temperatures.

There are three major types of deposits formed by fluids moving through the Nikolai Greenstone in central Alaska, exemplified by Kennecott, Kathleen-Margaret (K-M), and Caribou Dome (also known as Denali Copper), which are linked by similar metallogeny and mineral textures; in figure 32 we contrast them with the Early Cretaceous-age Zackly $\mathrm{Au}-\mathrm{Cu}$ skarn in the study area. Kennecott, an epigenetic copper sulfide replacement deposit hosted by limestone, has $\mathrm{Ag} / \mathrm{Cu}$ (ppm/percent) ratios ranging from 6 to 12 (fig. 32B), anomalous concentrations of $\mathrm{As}-\mathrm{Hg}-\mathrm{Sb}-\mathrm{Mo}$, and $\mathrm{Zn} / \mathrm{Cd}$ ratios ranging from 2 to 13 (fig. 32C). Kennecott displays a paragenesis of extremely rare pyrite replaced by chalcopyrite, replaced by bornite, and finally replaced by chalcocite (fig. 33). K-M, an epigenetic copper sulfide vein prospect hosted by Nikolai Greenstone, has $\mathrm{Ag} / \mathrm{Cu}$ ratios in the range of 1 to 12 (4 to 12 for bornite-rich samples, and $1-4$ for chalcopyrite-rich samples; fig. 32B), anomalous $\mathrm{As}-\mathrm{Sb}-\mathrm{Hg}-\mathrm{Re}$, and $\mathrm{Zn} / \mathrm{Cd}$ ratios in the range of 1 to 25 . K-M displays a consistent paragenesis of bornite replacing chalcopyrite (fig. 33). The variations in $\mathrm{Ag} / \mathrm{Cu}$ ratios are consistent with the higher solubility of Ag in bornite than that in chalcopyrite. Caribou Dome, historically considered to be a syngenetic stratiform chalcopyrite-pyrite deposit (Stevens, 1971; Seraphim, 1975) due to its variably fine-grained, framboidal pyrite, has $\mathrm{Ag} / \mathrm{Cu}$ ratios of $1-4$ (fig. 32B), anomalous Tl-Re-As, and $\mathrm{Zn} / \mathrm{Cd}$ ratios of 4-16. Such low $\mathrm{Zn} / \mathrm{Cd}$ ratios are typical of low-temperature epigenetic deposit types (such as MVT) but are much lower than $\mathrm{Zn} / \mathrm{Cd}$ ratios observed in SEDEX deposits or seafloor hydrothermal vents (Wen and others, 


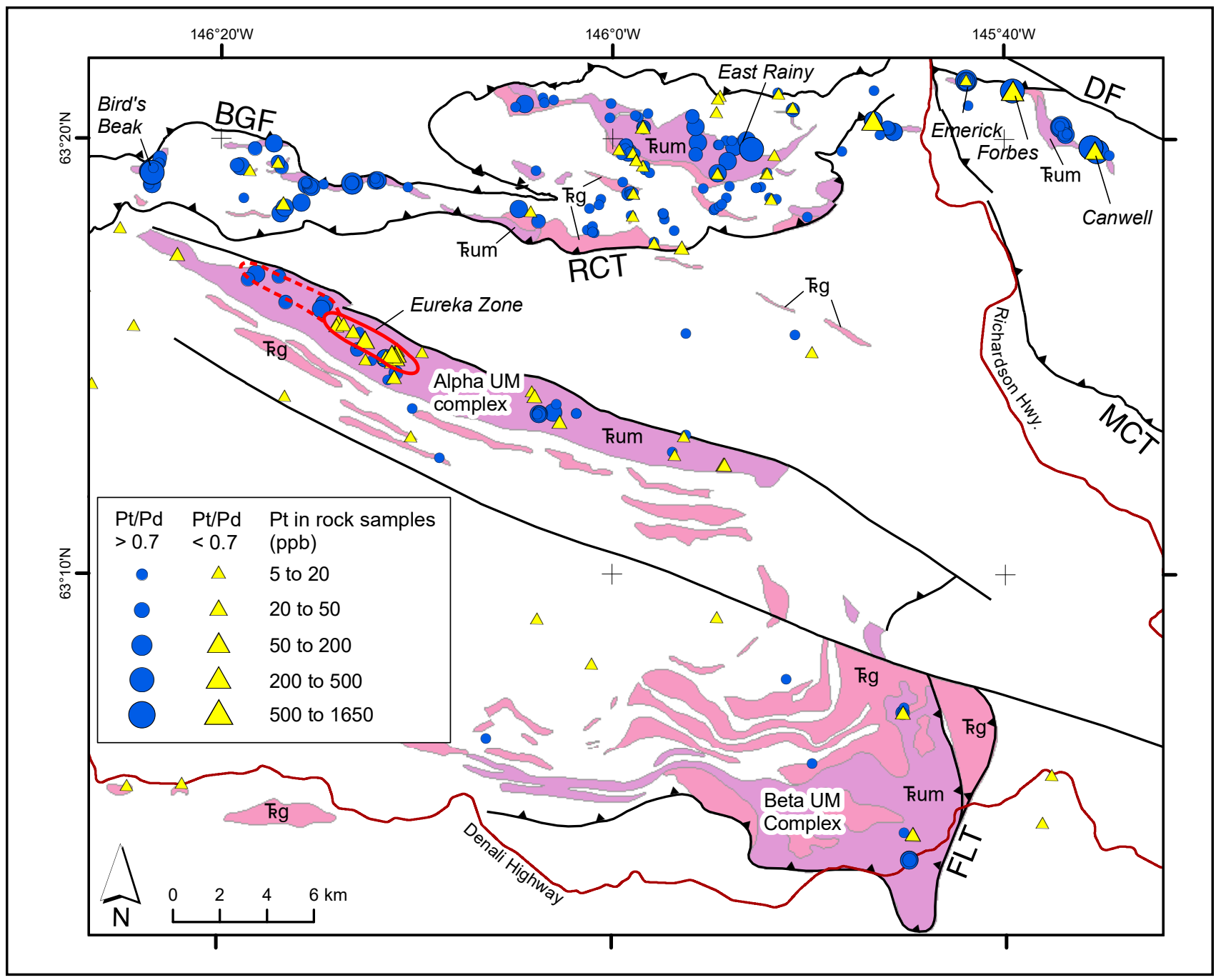

Figure 31. Pt/Pd ratios and Pt values from rock samples, mafic-ultramafic intrusions, and major faults in the Rainy Creek and Amphitheater Mountains (simplified from Twelker and others, 2020). Rock samples with Pt/Pd greater than 0.7, shown as blue circles, dominate mineralization in prospects north of the Rainy Creek (RCT) and McCallum Creek (MCT) thrust faults. Rock samples with Pt/Pd less than 0.7, shown as yellow triangles, dominate the core of the Eureka Zone (solid red outline). The western extension of the Eureka Zone (dashed red outline) has Pt/Pd greater than 0.7. Rock geochemistry from DGGS (Twelker and others, 2014a; Wypych and others, 2015), BLM (Bittenbender and others, 2007), and Pure Nickel Eureka zone drill intercepts (Pure Nickel Inc., 2013). Selected prospects labeled in italics. Abbreviations: FLT - Fish Lake Thrust; BGF _ Broxson Gulch Fault; DF - Denali Fault. See figure 3 for geological legend.

2016). By contrast, the Zackly skarn Au-Cu deposit occurs in similarly close proximity to the Nikolai Greenstone but has $\mathrm{Au} / \mathrm{Cu}$ ratios 10-10,000 times higher than those of other deposits and is enormously enriched in $\mathrm{Bi}$ and $\mathrm{Te}$ (tens to hundreds of $\mathrm{ppm}$ ) relative to the others (fig. 32D); $\mathrm{Zn} / \mathrm{Cd}$ values (30-110) are more consistent with high-temperature deposit types such as porphyry and skarn (Wen and others, 2016).

\section{Origin of the Caribou Dome $\mathrm{Cu}-\mathrm{Ag}$ deposit}

The genetic model for the Caribou Dome prospect is the most uncertain of the four. Our microprobe-based petrography shows that pyrite is consistently replaced by chalcopyrite (fig. 33), and suggests that the extremely low (-27 to $-30 \%) \delta^{34} \mathrm{~S}$ values present (Stevens, 1971) may be inherited from early, diagenetic framboidal pyrite (fig. 34). 
With increasing chalcopyrite content, pyrite and calcite decrease and $\mathrm{SiO}_{2}$ increases. The elements $\mathrm{Ag}, \mathrm{Tl}$, and $\mathrm{Sb}$ show strong to very strong positive correlations with $\mathrm{Cu}$; Re shows a modest correlation. The relatively high values for $\mathrm{Tl}$ (5 to 126.5 ppm) are consistent with Caribou Dome being the lowest-temperature deposit of the group of four considered here.

The observed ore mineralogy and paragenetic sequences, coupled with the preservation and inheritance of low biogenic $\delta^{34} S$ values, suggest Caribou Dome's Cu-mineralizing fluids were likely saline, oxidized, and did not carry significant reduced sulfide. Progressive replacement of diagenetic pyrite by a series of increasingly $\mathrm{Cu}$-rich and $\mathrm{Fe}$ - and S-poor mineral species is a characteristic pattern of sediment-hosted copper deposits worldwide (Hitzman and others, 2005).

The host stratigraphy of the Caribou Dome deposit, including argillites, minor limestone beds, and thin gabbro to peridotite intrusions, is most closely similar to the regional Permian to Triassic sedimentary and volcanic rocks (unit KPsv in fig. 3) that underlie the Nikolai Greenstone. We sampled a troctolite intruding the deposit area that assayed $101 \mathrm{ppb}$ Pt and 193 ppb Pd (sample 15ET102; Wypych and others, 2015); such intrusions commonly intrude the pre-Nikolai stratigraphy but are not recognized in post-Late Triassic rocks. The deposit area itself is separated from demonstrable Late Triassic sedimentary and volcanic rocks and fossil localities by strands of the regionally significant Talkeetna shear zone (Silberling and others, 1981; Mooney, 2010). The stratigraphic position of mineralization below the Nikolai Greenstone is in contrast to the position of most other mineralization in the region, which is hosted by overlying sediments (Kennecott ore bodies) or in the Nikolai Greenstone itself (for example, K-M and Lichen). Faulting may be responsible for placing the sulfiderich pre-Nikolai Greenstone sediments, the metal trap, hydrologically above the suspected metal source, the $\mathrm{Cu}$-rich Nikolai Greenstone (fig. 35).
In summary, we suggest that the Caribou Dome copper deposit could be placed on the continuum of sediment-hosted, epigenetic $\mathrm{Cu}-\mathrm{Ag}$ deposits related to fluid flow through the Nikolai Greenstone during metamorphism; if true, Caribou Dome would fall at the distal, low-temperature end member of this mineral system. Low $\delta^{34} S$ values and biogenic pyrite textures do not necessarily indicate a syngenetic origin for the copper mineralization. This evidence applies only to the diagenetic framboidal pyrite; the copper mineralization is apparently a later, sulfur-poor event. Future work to test this hypothesis could include direct dating of pyrite and chalcopyrite fractions by Re-Os; however, the grain size and intergrown nature of the mineralization present a major challenge.

\section{Mineralization related to intrusions other than Late Triassic}

The study area has been intruded by a succession of intermediate to felsic intrusions beginning in the Pennsylvanian and continuing episodically into the Quaternary; these intrusions represent a series of variously configured volcanic arcs that existed first in intra-oceanic settings, and later along the northwestern margin of North America. The timing and the tectonic setting of these intrusions has implications for interpretations of the area's mineral potential.

This section reports only on the findings of this study and is not a complete account of all mineralization in the study area. For a more comprehensive inventory and description of the mineralization of this area, refer to Bittenbender and others (2007), Kurtak and others (1991), and the Alaska Resource Data File (U.S. Geological Survey, 2018).

\section{Late Paleozoic Skolai arc}

The oldest intrusions examined during this study are thrust-fault-bound Late Pennsylvanian granitic rocks in the upper Eureka Creek area. These are thought to represent the plutonic roots of the Skolai arc. Mineral occurrences documented in the area, such as Bird's Beak (fig. 31; Ellis and others, 2004), are apparently related to ultramafic 


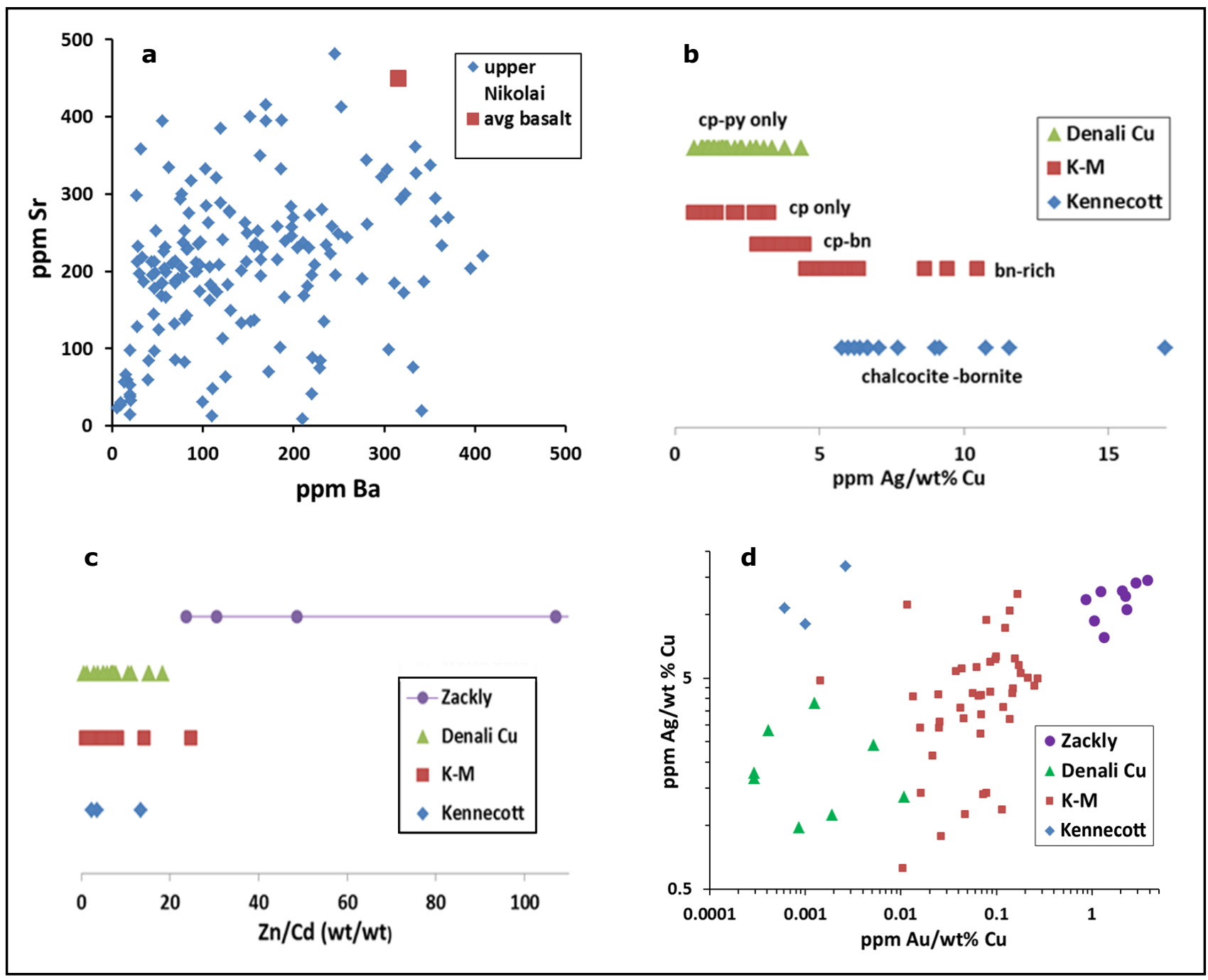

Figure 32. A. Mobile-element (Sr, Ba) compositional data for samples of upper Nikolai Greenstone and average, unaltered basalt (Gale and others, 2013). B. Ag/Cu ratios of mineralized samples by prospect and ore-mineral assemblage. C. Zn/ $\mathrm{Cd}$ ratios of mineralized samples by prospect. D. Ag/Cu versus Au/Cu ratios for copper-rich prospects in Wrangellia. Abbreviations: $p y=$ pyrite; $c p=$ chalcopyrite; $b n=$ bornite.

intrusions, presumably Late Triassic in age, which intrude the granitic rocks.

Permian granitic orthogneiss (fig. 8; unit Pcog of Twelker and others, 2020) from the Clearwater Mountains yielded a U-Pb zircon age of $268.05 \pm$ 11.64 Ma (Twelker and O'Sullivan, 2016). This metamorphosed pluton is spatially associated with the Mex prospect (fig. 2); however, a genetic relationship between the pluton and the mineralization is uncertain because the prospect is poorly understood and includes multiple styles. Some mineralization, including stibnite veins, crosscuts the orthogneiss, while other mineralization at Mex is described as closely related to north-dipping thrust faults (Ellis and others, 2004) that are likely Late Cretaceous to Cenozoic in age. The portion of mineralization described as base-metal skarns with high W values (Ellis and others, 2004) could be of Permian age.

\section{Jurassic Talkeetna arc}

A series of Middle Jurassic plutons intrude the Strelna metamorphic complex along the southern boundary of the study area (Wilson and others, 2015). One pluton of this series, dated at 163.1 
Kennecott:

local pyrite $\rightarrow$ chalcopyrite $\rightarrow$ bornite $\rightarrow$ chalcocite

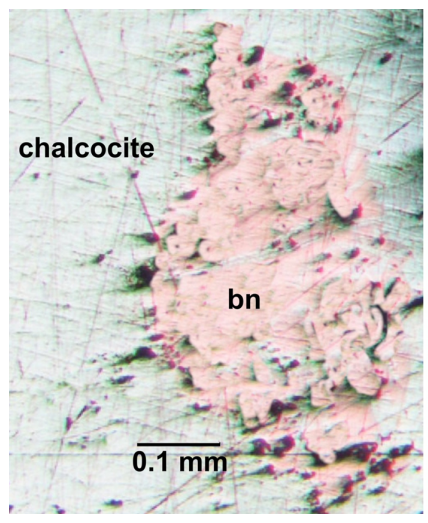

K-M:

chalcopyrite $\rightarrow$ bornite

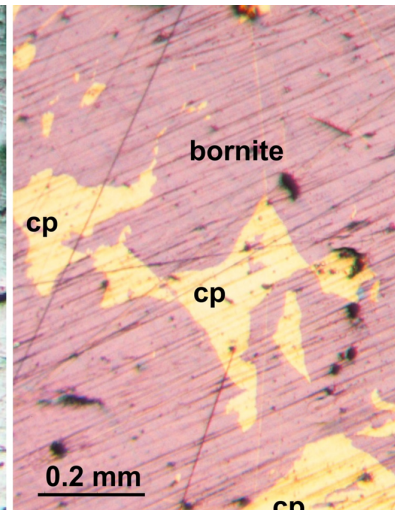

Caribou Dome: pyrite $\rightarrow$ chalcopyrite

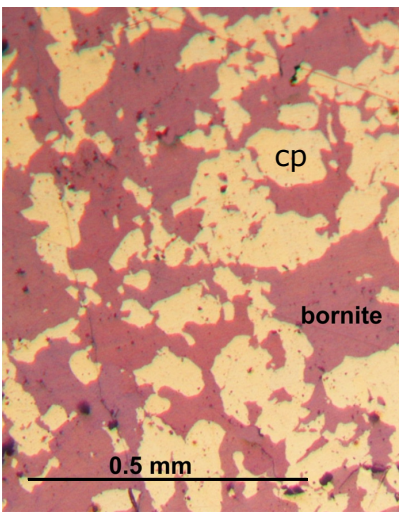

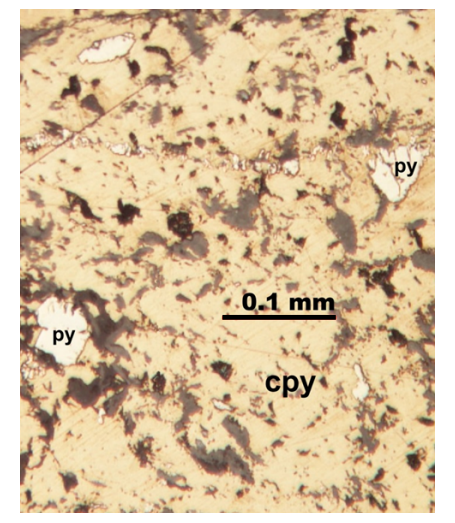

Figure 33. Photomicrographs (reflected light) showing replacement textures in sulfide mineralization: Kennecott (far left and left), K-M (middle), and Caribou Dome (right). Abbreviations: py - pyrite; cp/cpy - chalcopyrite; bn - bornite.
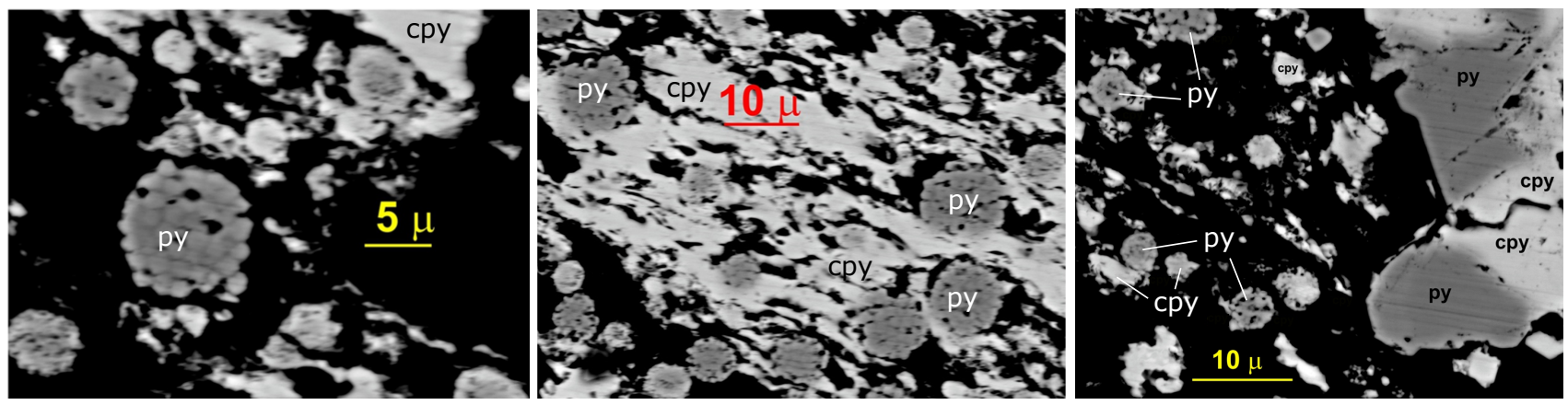

Figure 34. Energy dispersive spectroscopy images of chalcopyrite (brightest) replacing framboidal pyrite in Caribou Dome samples. Abbreviations: py - pyrite; cpy - chalcopyrite.

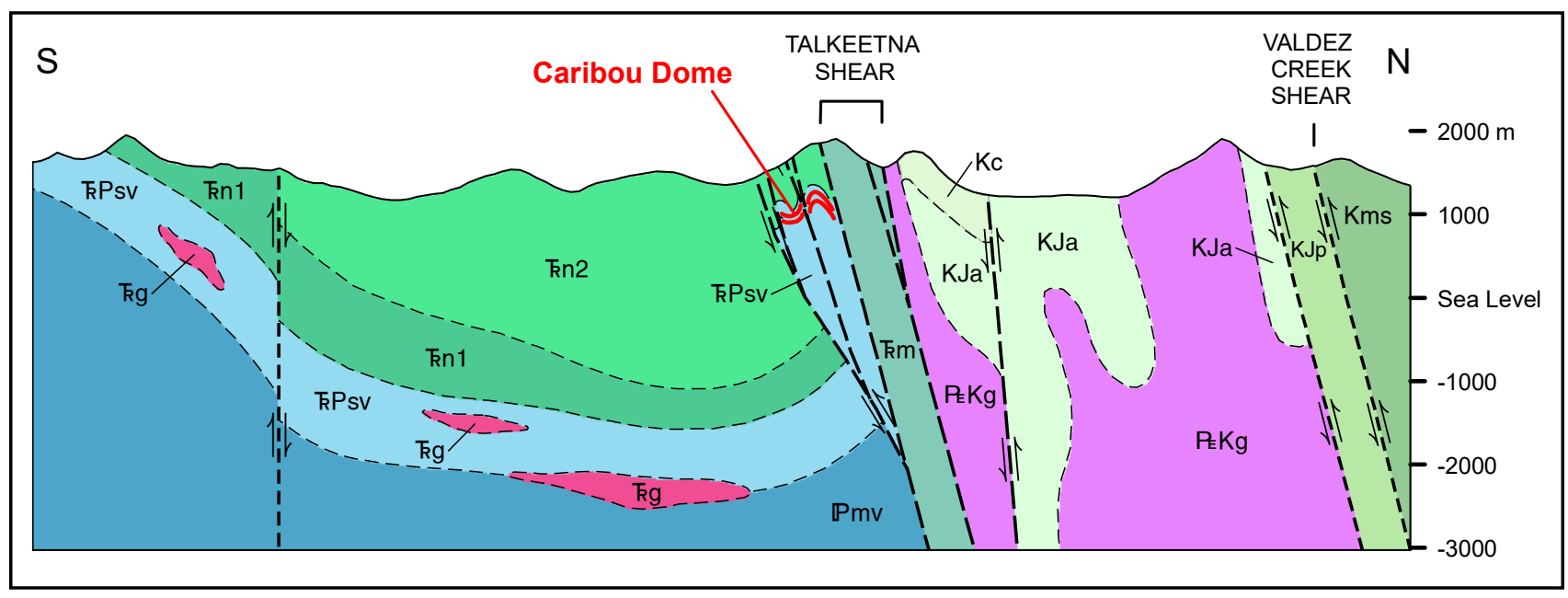

Figure 35. North-south cross section (no vertical exaggeration) through the Caribou Dome Cu-Ag deposit showing the present-day setting of the deposit. Faulting related to the Talkeetna shear zone emplaced the pyrite-rich, pre-Late Triassic sedimentary rocks over and adjacent to the copper-enriched upper member of the Nikolai Greenstone ( $\mathrm{kn} 2$ ). See figure 3 for section location and geological legend. Red lines are a schematic representation of sulfide mineralization. Section adapted from Twelker and others (2020). 
$\pm 1.3 \mathrm{Ma}$ (U-Pb zircon; Todd and others, 2017), intrudes greenschist-facies stratigraphy of the Wrangellia terrane in the Talkeetna Mountains C-4 Quadrangle (unit Jgd in fig. 4). This granodiorite to tonalite pluton has approximately $18 \mathrm{sq} \mathrm{km}$ of exposure and an estimated crystallization pressure of 3.6 kilobars based on amphibole compositions (Twelker and others, 2015b). Skarn-like mineralization is locally developed in sedimentary rocks at the pluton contacts. These occurrences, sites 3 and 4 in the appendix of this report, are characterized by calc-silicates (actinolite or tremolite, clinopyroxene, garnet), copper sulfides, pyrite, and locally abundant magnetite. ${ }^{40} \mathrm{Ar} /{ }^{39} \mathrm{Ar}$ dating indicates an age of $165.2 \pm 2.1 \mathrm{Ma}$ for alteration amphibole (occurrence 3 of this report; Benowitz and others, 2014).

\section{Chisana arc mineralization}

The Zackly prospect is a gold-copper-silver skarn hosted in Late Triassic Wrangellia sedimentary rocks intruded by a quartz monzodiorite to monzonite stock. Where unaltered, the stock has an average magnetic susceptibility of $41 \times 10^{-3}$ SI, suggesting an oxidized-type magma typical of volcanic arc settings. Biotite from an unaltered portion of this intrusion yielded an ${ }^{40} \mathrm{Ar} /{ }^{39} \mathrm{Ar}$ age of $124.6 \pm 0.5 \mathrm{Ma}$ (Benowitz and others, 2014), which is thought to reflect the approximate age of intrusion emplacement and skarn formation.

Evidence from this region suggests that full accretion of Wrangellia did not occur until the Late Cretaceous (Davidson and McPhillips, 2007; Hults and others, 2013), and the belt of Early Cretaceous plutons along the northern edge of Wrangellia reflects a south-facing arc, the Chisana arc, established on the Insular terranes during this time (Trop and Ridgeway, 2007). Other prospects in the region that are similar to the Early Cretaceous Zackly skarn in terms of age, style, and tectonic setting are the Grubstake copper-gold porphyry and the Ravine skarn systems in the Chisana area, located $140 \mathrm{~km}$ to the east (Myers and others, 2015).

\section{Cretaceous to Cenozoic arc-related mineralization}

Small stocks of hornblende gabbro to hornblende monzogabbro intrude the Wrangellia and Jurassic-Cretaceous metaflysch in the central Talkeetna Mountains (Twelker and others, 2015a). These have a range of middle to Late Cretaceous ${ }^{40} \mathrm{Ar} /{ }^{39} \mathrm{Ar}$ ages, including $76.9 \pm 0.5 \mathrm{Ma}$ (Benowitz and others, 2015) and $105.8 \pm 0.4 \mathrm{Ma}$ (Benowitz and others, 2014). The gabbro-monzogabbro intrusions contain abundant magnetite (median magnetic susceptibility of $16.50 \times 10^{-3} \mathrm{SI}$; Twelker and others, 2015a), suggestive of a relatively high oxidation state magma. Regionally, coeval oxidizedtype intrusions along trend in the Alaska Range to the southwest are highly prospective for porphyry copper mineralization (for example, Nyac, Pebble, and Whistler; Graham and others, 2013).

Latest Cretaceous to early Paleogene intrusions in the central Talkeetna Mountains have a reduced, nonmagnetic character, with median magnetic susceptibility of $0.30 \times 10^{-3} \mathrm{SI}$ (unit $\mathrm{Kg}$; Twelker and others, 2015a). U-Pb zircon methods indicate an age of $62.7 \pm 0.5 \mathrm{Ma}$ (Todd and others, 2017) for the deeply exposed, medium- to coarsegrained granitic plutons in the northwest Talkeetna Mountains C-4 Quadrangle. Porphyry intrusions of similar composition and age(?) intrude Wrangellia and Jurassic-Cretaceous flysch farther to the southeast, separated from the more deeply exhumed plutons by the Range Front fault (fig. 10; Twelker and others, 2015a). Occurrence 1 of this report is one such intrusion. It is pervasively altered to a propylitic assemblage and mineralized with disseminated and quartz-veinlet-hosted chalcopyrite and pyrite. It carries anomalous $\mathrm{Au}, \mathrm{Ag}, \mathrm{Mo}, \mathrm{In}$, Sn, Re, Bi, and Te (Wypych and others, 2014). This trace element signature is typical of reduced intrusion-related mineralization in the regional context (Clautice and others, 2001). The Ag/Au ratio ( 20), relatively low $\mathrm{Sn}$ values, and inferred age suggest a possible correlation with mineral systems such as the Golden Zone deposit $80 \mathrm{~km}$ to the northwest. 


\section{Structurally controlled mineralization in the Talkeetna Mountains}

Many of the mineral occurrences described in this report are structurally controlled and occur within a northeast-trending corridor cutting through the central Talkeetna Mountains (fig. 4; appendix). This corridor is centered on the multistrand Central Raingellia fault system and associated parallel structures. The interaction of these structures with a series of Paleogene volcanic fields provides constraints on the age and structural and metallogenic history of the area.

Occurrences potentially related to the Central Raingellia fault include $\mathrm{Mo}-\mathrm{Cu}$ mineralization at Peak 6045 (site 5; fig. 4), vein-hosted gold mineralization north of Peak 6910 (site 2), shear-hosted $\mathrm{Cu}-\mathrm{Ag}$ mineralization north of the Talkeetna River (site 6), the King and Queen Au prospect, where the highest gold grades occur in fracture zones (site 8), and Sb-As-mineralized breccias at Peak 5380 (site 11). Although skarn-like occurrences north of Peak 6910 (site 3) and southwest of Peak 6086 (site 4) lie within the Central Raingellia fault corridor, ${ }^{40} \mathrm{Ar} /{ }^{39} \mathrm{Ar}$ dating of hydrothermal amphibole at site 3 indicates a Jurassic age (Benowitz and others, 2014).

Mineralization in these prospects tends to reflect the composition of local host rocks. At site 6, the $\mathrm{Cu}$-rich Nikolai Greenstone hosts the Ag-bearing bornite veinlets, a metal association that is typical of greenstone-hosted $\mathrm{Cu}$ occurrences throughout Wrangellia in central Alaska. Gold mineralization at King and Queen (site 8) and Canyon (site 10) occurs with felsic volcanic rocks, as does the Sb-As mineralization at site 11. These elements are enriched in evolved magmas, and deposits of this type are often associated with felsic intrusions.

As discussed in the structural geology section of this report, the Central Raingellia fault is a complex high-angle fault system with multiple episodes of slip, including both ductile deformation and brittle overprint (Sicard and others, 2015). Crosscutting relationships between these faults and the series of Paleogene to Eocene volcanic fields indicate that the central Talkeetna Mountains experienced brittle deformation and magmatism concurrently. The combination of structural preparation, subvolcanic intrusions, and high heat flow associated with volcanic activity make this area prospective for epithermal mineralization. Occurrences more likely of mesothermal character (site 2 north of Peak 6910) may be related to earlier ductile activity on the Central Raingellia fault, the timing of which is not constrained by the volcanic fields.

\section{CONCLUSIONS}

- The generalized stratigraphy of Wrangellia in the eastern Alaska Range and the central Talkeetna Mountains comprises a thick unit of mafic to intermediate volcanic rocks overlain by a discontinuous unit of felsic volcanic rocks, both of Pennsylvanian age. These are overlain by a mixed assemblage of sedimentary and volcanic rocks with Permian and, locally, Early Triassic ages. These rocks are the primary host for mostly sill-form intrusions of gabbroic to ultramafic (olivine \pm clinopyroxene cumulate) compositions. These are cogenetic to the Late Triassic Nikolai Greenstone, which we have subdivided into a stratigraphically lower, discontinuous low-Ti member, and a thicker, more regionally extensive high-Ti member. Very primitive equivalents to the Nikolai Greenstone, the Rainy Creek picrites, occur in the Rainy Creek area. Post-Nikolai Greenstone limestone and shale are only locally preserved in the region.

- In the central Talkeetna Mountains, the Wrangellia stratigraphic section is thickened and duplicated by a series of northwest-vergent thrust faults. Early Jurassic metamorphic cooling ages in the hinterland (southeastern edge of Wrangellia) suggest that this shortening may have occurred prior to the accretion of the combined Wrangellia and Peninsular terranes to the North American margin. 
- Our mapping did not locate the previously described Talkeetna thrust (Csejtey and others, 1978). Instead, our work supports the crustal-scale Talkeetna suture zone (Glen and others, 2007), which is represented by a series of northeast-striking, high-angle brittle and ductile structures in the central Talkeetna Mountains. Of these structures, the Range Front fault likely accommodated multiple kilometers of dip-slip motion between 63 and 45 Ma. Subsequently, deformation shifted southeast to structures including the Central Raingellia fault, which saw at least $1 \mathrm{~km}$ of dip-slip motion, plus unknown strike-slip motion, between 54 and $38 \mathrm{Ma}$. After $38 \mathrm{Ma}, 1.6 \mathrm{~km}$ of right-lateral offset is apparent.

- In the Amphitheater Mountains area, the Wrangellia stratigraphic section has been duplicated by large-scale, south-vergent thrust faulting, likely during the Late Cretaceous. The base of the thrust panel is formed by serpentinized dunite of the Alpha (Fish Lake) and Beta (Tangle) ultramafic complexes.

- In the Clearwater and Amphitheater Mountains, a series of Cenozoic west-northwest-striking high-angle faults have dip-slip offsets and a mix of dip-slip and right-lateral kinematics. These faults suggest a localized transtensional environment developed near the junction of the Denali fault and the Talkeetna suture zone in response to regional right-lateral tectonics.

- Tholeiitic magmas of the Late Triassic Nikolai Greenstone magmatic province can be subdivided by geochemistry into low- $\mathrm{Ti}$, high- $\mathrm{Ti}$, and Rainy Creek series. The Rainy Creek picrites are closely similar to the high-Ti series melts in terms of REE and most HFSE ratios, and they appear to be primitive relatives of this series.

- Petrographic evidence suggests that Rainy Creek picrite volcanic rocks represent primitive melts rather than olivine cumulates.

- Detailed mapping and mineral geochemistry show that the Alpha (or Fish Lake) ultramafic complex is a multiphase sill complex and not a layered mafic intrusion.
- Concentrations of PGEs normalized to 100 percent sulfide are much lower than would be expected if the mineralization were formed according to the layered mafic intrusion (or “reef”) PGE-deposit model.

- The $\mathrm{Ni} / \mathrm{Cu}$ ratios of $\mathrm{Ni}-\mathrm{Cu}-\mathrm{Co}-\mathrm{PGE}$ sulfide mineralization in the study area are consistent with "class 1" Ni-Cu-Co-PGE deposits related to gabbroic magmas; however, $\mathrm{S} / \mathrm{Ni}$ ratios are ambiguous, and some samples are more similar to mineralization related to picrite or komatiite magmas ("class 2"; Barnes and Lightfoot, 2005).

- The association of $\mathrm{Ni}-\mathrm{Cu}-\mathrm{Co}-\mathrm{PGE}$ mineralization with a specific magma series is somewhat ambiguous. The mineralization sampled is not derived from the magmas of the regionally extensive and more evolved high-Ti series Nikolai Greenstone. Most mineralization has $\mathrm{Pt} / \mathrm{Pd}$ ratios similar to either the Rainy Creek picrite series or the low-Ti series, and where PGE-mineralized samples have measurable rare earth elements, their ratios are similar to those of the Rainy Creek picrites. However, evidence for hybridization between magma series may allow for sulfide derived from low-Ti series magmas to be incorporated by later Rainy Creek magmas or primitive high-Ti series magmas.

- The highest Ni-Cu-Co-PGE grades are associated with a minority of Late Triassic mafic to ultramafic intrusions that were emplaced into the deepest levels of the Wrangellia section, the Pennsylvanian granitic rocks.

- Progressive enrichment of Pd and Cu with fractionation indicates that the majority of Nikolai magmas evolved under sulfide-undersaturated conditions. This magmatic $\mathrm{Cu}$ enrichment in the high-Ti series Nikolai volcanic rocks likely played a role in the formation of the Kennecott and Caribou Dome sediment-hosted Cu deposits.

- Epigenetic $\mathrm{Cu}$ mineralization associated with Nikolai Greenstone shows a consistent paragenesis of pyrite-chalcopyrite-bornite-chalcocite; this pattern is consistent with interaction of saline, 
sulfide-poor (oxidized), copper-bearing hydrothermal fluids with a reduced or sulfide-rich trap.

- Available data for Caribou Dome are not inconsistent with an epigenetic origin for $\mathrm{Cu}$ mineralization, but we accept a syngenetic origin for the pyrite there. We suggest that the $\mathrm{Cu}$ mineralization is a distal, low-temperature expression of the mineral system similar to that which formed the Kennecott $\mathrm{Cu}-\mathrm{Ag}$ deposit and the K-M $\mathrm{Cu}-\mathrm{Ag}$ prospect.

- Sediment-hosted $\mathrm{Cu}$ mineralization at Caribou Dome is most likely hosted by pre-Nikolai-Greenstone Permian to Early Triassic sedimentary rocks, rather than by post-Nikolai Late Triassic sedimentary rocks.

- The Zackly Au-Cu skarn system apparently formed during the Early Cretaceous and is related to the Chisana magmatic arc developed on Wrangellia prior to full accretion with North America in the Late Cretaceous.

- Structurally controlled epigenetic mineral occurrences follow, and are apparently related to, the interaction of Eocene brittle deformation and concurrent magmatic activity in the central Talkeetna Mountains.

\section{ACKNOWLEDGMENTS}

This project would not have been possible without the field contributions of DGGS geologists David A. Reioux, Erik N. Bachmann, Amy L. Tuzzolino, and T. Colby Wright, and the geophysical contributions of Laurel E. Burns, Abraham M. Emond, and Gina R.C. Graham. Melanie B. Werdon, Trevor S. Waldien, and Sarah M. Roeske contributed with geologic discussions and technical reviews. Collaborative work with Jeff A. Benowitz and Paul W. Layer of the UAF Geochronology Lab, Paul O’Sullivan of GeoSep Services, and USGS researchers Erin Todd and James V. Jones III was invaluable to our understanding of the geology. John Hoppe helped us with the U.S. Bureau of Land Management (BLM) geochemical dataset. We thank Jeanine M. Schmidt and Sarah M. Roeske for constructive reviews of the final manuscript.

Geological discussions with Jeanine M. Schmidt, Melanie B. Werdon, Peter Oswald, and Ben Porterfield got us started in the central Talkeetna Mountains. Jon Findlay, Bill Ellis, Katherine Smuk, and Erik Scheel helped to orient us to the magmatic $\mathrm{Ni}-\mathrm{Cu}-\mathrm{Co}-\mathrm{PGE}$ systems of the region, and Ben Vallerine and Phil St. George guided our examination of prospects in the Clearwater Mountains. We thank Dave McPherson and Lisa Buchan of Galleon Gold Corp (formerly known as Pure Nickel Inc.) for core donations to the DGGS Geologic Materials Center and access to the Pure Nickel dataset, which helped to guide our work.

We acknowledge Cook Inlet Region Inc. (CIRI), Chickaloon Moose Creek Native Association, Knikatnu, Ninilchik Natives Association, Salamatof Native Association, Seldovia Native Association, and Tyonek Native Corporation for providing access to private lands in the study area. Brenda Becker of the BLM Glennallen field office assisted us with permitting on BLM-managed lands.

This project was funded by the Alaska Legislature as part of the State's Strategic and Critical Minerals Assessment project (part of the DGGS Airborne Geophysical/Geological Mineral Inventory [AGGMI] program). Fieldwork in summer 2014 in the Talkeetna Mountains was also partially funded by the USGS National Cooperative Geologic Mapping Program, STATEMAP component, under award number G14AC00167 for 2014. The views and conclusions contained in this document are those of the authors and should not be interpreted as necessarily representing the official policies, either expressed or implied, of the U.S. Government. 


\section{REFERENCES}

Allen, W.K., 2016, Miocene-Pliocene strike-slip basin development along the Denali fault system in the eastern Alaska Range: Chronostratigraphy and provenance of the McCallum formation and implications for displacement: West Lafayette, Indiana, Purdue University, M.S. thesis, 146 p.

Anderson, R.E., 1969, Preliminary geochemistry and geology, Little Falls Creek area, Talkeetna Mountains. Quadrangle, Alaska: Alaska Division of Mines and Geology Geochemical Report 19, 16 p., 1 sheet, scale 1:42,240. http://doi. org/10.14509/254

Arndt, N.T, 2011, Insights into the Geologic Setting and Origin of Ni-Cu-PGE Sulfide Deposits of the Norilsk-Talnakh Region, Siberia, in $\mathrm{Li}$, Chusi and Ripley, E.M., eds., Magmatic Ni-Cu and PGE Deposits: Geology, Geochemistry, and Genesis: Society of Economic Geologists Reviews in Economic Geology, v. 17, p. 199-215.

Arndt, N.T., Lesher, C.M., and Czamanske, G.K., 2005, Mantle-derived magmas and magmatic NiCu-(PGE) deposits, in, Hedenquist, J.W., Thompson, J.F.H., Goldfarb, R.J., and Richards, J.P., eds., Economic Geology 100th Anniversary Volume: Society of Economic Geologists, p. 5-23.

Athey, J.E., and Werdon, M.B., 2018, Alaska's mineral industry 2017: Alaska Division of Geological \& Geophysical Surveys Special Report 73, 92 p. http://doi.org/10.14509/30075

Balen, M.D., 1990, Geochemical sampling results from Bureau of Mines investigations in the Valdez Creek mining district, Alaska: U.S. Bureau of Mines Open-File Report 34-90, 218 p., 2 sheets, scale 1:63,360. http://dggs.alaska.gov/ pubs/id/21384

Barnes, S-J., and Lightfoot, P.C., 2005, Formation of magmatic nickel-sulfide ore deposits and processes affecting their copper and platinum-group element contents, in Hedenquist, J.W., Thompson, J.F.H., Goldfarb, R.J., and Richards, J.P., eds., Economic Geology 100th Anniversary Volume, p. 179-213.

Beard, J.S., and Barker, Fred, 1989, Petrology and tectonic significance of gabbros, tonalites, shosho- nites, and anorthosites in a late Paleozoic arc-root complex in the Wrangellia terrane, southern Alaska: Journal of Geology, v. 97, no. 6, p. 667-683. Benowitz, J.A., Layer, P.W., and Twelker, Evan, 2014, ${ }^{40} \mathrm{Ar} /{ }^{39} \mathrm{Ar}$ data from rocks collected in 2013 in the Wrangellia mineral assessment area, Gulkana, Healy, Mount Hayes, and Talkeetna Mountains quadrangles, Alaska: Alaska Division of Geological \& Geophysical Surveys Raw Data File 2014-18, 10 p. http://doi. org/10.14509/29119

Benowitz, J.A., Layer, P.W., Wypych, Alicja, and Twelker, Evan, 2015, ${ }^{40} \mathrm{Ar} /{ }^{39} \mathrm{Ar}$ data from the Talkeetna Mountains C-4 Quadrangle and adjoining areas, central Alaska: Alaska Division of Geological \& Geophysical Surveys Raw Data File 2015-10, 19 p. http://doi.org/10.14509/29454

$2017,{ }^{40} \mathrm{Ar} /{ }^{39} \mathrm{Ar}$ data from rocks collected in the 2015 Wrangellia mineral assessment project area, Mount Hayes A-5, Mount Hayes B-6, and Talkeetna Mountains D-2 quadrangles, Alaska: Alaska Division of Geological \& Geophysical Surveys Raw Data File 2017-1, 9 p. http://doi. org/10.14509/29699

Bittenbender, P.E., Bean, K.B., Kurtak, J.M., and Deininger, James, 2007, Mineral assessment of the Delta River Mining District area, east-central Alaska: U.S. Bureau of Land Management, BLM Alaska Technical Report 57, 697 p.

Burns, L.E., CGG, and Fugro GeoServices, Inc., 2014a, Wrangellia survey area: Airborne magnetic and electromagnetic data in line (point), grid, vector, and map formats, Talkeetna Mountains, Healy, and Mt. Hayes quadrangles, south-central Alaska: Alaska Division of Geological \& Geophysical Surveys Geophysical Report 20141, 56 sheets, scale 1:63,360, 1 DVD. http://doi. org/10.14509/27022

Burns, L.E., Fugro Airborne Surveys Corp., and Stevens Exploration Management Corp., 2004, Line, gridded, and vector data, and selected plot files of the airborne geophysical survey data of the Valdez Creek mining district, central Alaska: Alaska Division of Geological \& Geophysical Surveys Geophysical Report 2004-3, 1 DVD. http://doi.org/10.14509/3337 
Burns, L.E., Geoterrex-Dighem, WGM, Inc., Emond, A.M., and Graham, G.R.C., 2014b, Iron Creek airborne electromagnetic and magnetic geophysical survey data compilation: Alaska Division of Geological \& Geophysical Surveys Geophysical Report 2014-6. http://doi. org/10.14509/27360

Burns, L.E., U.S. Bureau of Land Management, Fugro Airborne Surveys, and Stevens Exploration Management Corp., 2003, Plot files of the airborne geophysical survey data of the southern Delta River area, east-central Alaska: Alaska Division of Geological \& Geophysical Surveys Geophysical Report 2003-5, 1 DVD. http://doi. org/10.14509/2904

Carr, M.J., and Gazel, Esteban, 2017, Igpet software for modeling igneous processes: examples of application using the open educational version: Mineralogy and Petrology, v. 111, p. 283-289.

Cawthorn, R.G., Barnes, S.J., Ballhaus, C., and Malitch, K.N., 2005, Platinum group element, chromium, and vanadium deposits in mafic and ultramafic rocks, in Hedenquist, J.W., Thompson, J.F.H., Goldfarb, R.J., and Richards, J.P., eds., Economic Geology 100th Anniversary Volume: Society of Economic Geologists, p. 215-249.

Clautice, K.H., Newberry, R.J., Blodgett, R.B., Bundtzen, T.K., Gage, B.G., Harris, E.E., Liss, S.A., Miller, M.L., Reifenstuhl, R.R., Clough, J.G., and Pinney, D.S., 2001, Bedrock geologic map of the Chulitna region, southcentral Alaska: Alaska Division of Geological \& Geophysical Surveys Report of Investigation 20011A, 31 p., 1 sheet, scale 1:63,360. http://doi. org $/ 10.14509 / 2768$

Clautice, K.H., Smith, T.E., Pessel, G.H., and Solie, D.N., 1989, Geology and mineral occurrences, upper Clearwater Creek area, Mt. Hayes A-6 Quadrangle, Alaska: Alaska Division of Geological \& Geophysical Surveys Public Data File 8918, 14 p., 2 sheets, scale 1:24,000. http://doi. org/10.14509/1421

Colpron, Maurice and Nelson, J.L., 2011, A digital atlas of terranes for the Northern Cordillera: British Columbia Ministry of Energy, Mines, and Petroleum Resources, GeoFile 2011-11. http://www.empr.gov.bc.ca/Mining/Geoscience/ PublicationsCatalogue/GeoFiles/Pages/2011-11.aspx Cox, D.P., and Singer, D.A., 1986, Mineral deposit models: U.S. Geological Survey Bulletin 1693, $398 \mathrm{p}$.

Csejtey, Bela, Jr., and Miller, R.J., 1978, Map and table describing metalliferous and selected nonmetalliferous mineral deposits, Talkeetna Mountains Quadrangle, Alaska: U.S. Geological Survey Open-File Report 78-558-B, 20 p., 1 sheet, scale 1:250,000.

Csejtey, Bela, Jr., Nelson, W.H., Jones, D.L., Silberling, N.J., Dean, R.M., Morris, M.S., Lanphere, M.A., Smith, J.G., and Silberman, M.L., 1978, Reconnaissance geologic map and geochronology, Talkeetna Mountains Quadrangle, northern part of Anchorage Quadrangle, and southwest corner of Healy Quadrangle, Alaska: U.S. Geological Survey Open-File Report 78-558-A, 60 p., 1 sheet, scale 1:250,000.

Davidson, Cameron, Hollister, L. S., and Schmid, S. M., 1992, Role of Melt in the Formation of a Deep-crustal Compressive Shear zone: The Maclaren Glacier Metamorphic Belt, south central Alaska: Tectonics, v. 11, p. 348-359.

Davidson, Cameron, and McPhillips, Devin, 2007, Along strike variations in metamorphism and deformation of the strata of the Kahiltna basin, south-central Alaska, in, Ridgway, K.D., Trop, J.M., Glen, J.M.G., and O’Neill, J.M., eds., Tectonic growth of a collisional continental margin: Crustal evolution of southern Alaska: Geological Society of America Special Paper 431, p. 439-454.

Dusel-Bacon, Cynthia, 1994, Metamorphic rocks of Alaska, in Plafker, George, and Berg, H.C., eds., The Geology of Alaska: Geological Society of America, 2 sheets, scale 1:2,500,000.

Ellis, W.T., 2000, Exploration Update Ni/Cu/ PGE Mineralization in the Triassic of Eastern Wrangellia, Central Alaska Range [abs.]: Alaska Miners Association Annual Convention, Anchorage, Alaska, October 30-November 4, 2000, p. 35. 
Ellis, W.T., Hawley, C.C., and Dashevsky, S.S., 2004, Alaska resource data file, Mount Hayes Quadrangle, Alaska: U.S. Geological Survey Open-File Report 2004-1266, 742 p.

Findlay, Jon, 2013, An overview of Pure Nickel Inc.'s MAN and Salt Chuck exploration projects in Alaska [abs.]: Alaska Miners Association Annual Convention, Anchorage, Alaska, November 4-10, 2013, p. 31.

Gale, Allison, Dalton, C.A., Langmuir, C.H., Su, Yongjun, and Schilling, J.G., 2013, The mean composition of ocean ridge basalts: Geochemistry, Geophysics, Geosystems, v. 14, p. 489-518. http://doi.org/10.1029/2012GC004334

Glen, J.M.G., Schmidt, J.M., and Connard, G.G., 2011, Three-dimensional model of an ultramafic feeder system to the Nikolai Greenstone mafic large igneous province, central Alaska Range: Geochemistry, Geophysics, Geosystems, v. 12, 24 p. http://doi.org/10.1029/2011GC003508

Glen, J.M.G., Schmidt, J., Pellerin, L., McPhee, D.K., and O'Neill, J.M., 2007, Crustal structure of Wrangellia and adjacent terranes inferred from geophysical studies along a transect through the northern Talkeetna Mountains, in Ridgway, K.D., Trop, J.M., Glen, J.M.G., and O'Neill, J.M., eds., Tectonic growth of a collisional continental margin: Crustal evolution of southern Alaska: Geological Society of America Special Paper 431, p. 21-42. http://doi. org/10.1130/2007.2431(02)

Graham, G.E., Goldfarb, R.J., Miller, Marti, Gibler, Kati, and Roberts, Mike, 2013, Tectonic evolution and Cretaceous gold metallogenesis of southwestern Alaska, in Colpron, Maurice, Bissig, Thomas, Rusk, B.G., and Thompson, J.F.H., Tectonics, Metallogeny, and Discovery: The North American Cordillera and Similar Accretionary Settings: Society of Economic Geologists Special Publication Number 17, p. 169-200.

Granitto, Matthew, Schmidt, J.M., Shew, N.B., Gamble, B.M., and Labay, K.A., 2013, Alaska Geochemical Database, Version 2.0 (AGDB2) including "best value" data compilations for rock, sediment, soil, mineral, and concentrate sample media: U.S. Geological Survey Data Series 759, 20 p., pamphlet and database, 1 DVD. https://pubs.usgs.gov/ds/759/

Greene, A.R., Scoates, J.S., and Weis, Dominique, 2008, Wrangellia flood basalts in Alaska-A record of plume-lithosphere interaction in a Late Triassic accreted oceanic plateau: Geochemistry, Geophysics, Geosystems, v. 9, no. 12, 32 p. http://doi.org/10.1029/2008GC002092

Greene, A.R., Scoates, J.S., and Weis, D., Katvala, E.C., Israel, S., and Nixon, G.T., 2010, The architecture of oceanic plateaus revealed by the volcanic stratigraphy of the accreted Wrangellia oceanic plateau: Geosphere, v. 6, no. 1, p. 47-73. Hampton, B.A., Ridgway, K.D., O’Neill, J.M., Gehrels, G.E., Schmidt, J.M and Blodgett, R.B., 2007, Pre-, syn-, and post-collisional stratigraphic framework and provenance of Upper Triassic-Upper Cretaceous strata in the northwestern Talkeetna Mountains, Alaska, in Ridgway, K.D., Trop, J.M., O’Neill, J.M., and Glen, J.M.G., eds., Tectonic growth of a collisional continental margin: Crustal evolution of southern Alaska: Geological Society of America Special Paper 431, p. 401438. http://doi.org/10.1130/2007.2431(16)

Hauri, E.H., Wagner, T.P., and Grove, T.L., 1994, Experimental and natural partitioning of Th, U, $\mathrm{Pb}$ and other trace elements between garnet, clinopyroxene and basaltic melts: Chemical Geology, v. 117 , p. 149-166.

Hitzman, M.W., Kirkham, Rodney, Broughton, David, Thorson, Jon, and Selley, David, 2005, The sediment-hosted stratiform copper ore system, in Hedenquist, J.W., Thompson, J.F.H., Goldfarb, R.J., and Richards, J.P., eds., Economic Geology 100th Anniversary Volume: Society of Economic Geologists, p. 609-642.

Hulbert, L.J., 1997, Geology and metallogeny of the Kluane mafic-ultramafic belt, Yukon Territory, Canada: eastern Wrangellia_-a new Ni-Cu-PGE Metallogenic terrane: Geological Survey of Canada Bulletin 506, 265 p.

Hulbert, L.J. and Stone, W., 2006, Eastern Wrangellia - A New Ni-Cu-PGE Metallogenic Terrane in North America. ASEG Extended Abstracts 2006: 18th Geophysical Conference: p. 1-7. 
Hults, C.P., Wilson, F.R., Donelick, R.A., and O'Sullivan, P.B., 2013, Two flysch belts having distinctly different provenance suggest no stratigraphic link between the Wrangellia composite terrane and the paleo-Alaskan margin: Lithosphere, v. 5, no. 6, p. 575-594.

Jaques, A.L., and Green, D.H., 1980, Anhydrous melting of peridotite at $0-15 \mathrm{~kb}$ pressure and the genesis of tholeiitic basalts: Contributions to Mineralogy and Petrology, v. 73, p. 287-310.

Jones, D.L., Silberling, N.J., Coney, P.J., and Plafker, George, 1987, Lithotectonic terrane map of Alaska (west of the 141st meridian): U.S. Geological Survey Miscellaneous Field Studies Map 1874-A, 1 sheet, scale 1:2,500,000.

Jones, J.V. III, Todd, Erin, Caine, J.S., Holm-Denoma, C.S., Ryan, J.J., and Benowitz, J.A., 2017, Late Permian (ca. 267-257 Ma) magmatism, deformation, and metamorphism and lithotectonic associations of the Ladue River unit in east-central Alaska: Geological Society of America Abstracts with Programs, v. 49, no. 6.

Kalkowski, Tomasz, 2012, Characterization of platinum group minerals from the MAN Ni$\mathrm{Cu}-\mathrm{PGE}$ project, Alaska: Ottawa, University of Ottawa, Ontario, Canada, M.Sc. thesis, 72 p.

Kurtak, J.M., Southworth, D.D., Balen, M.D., and Clautice, K.H., 1991, Mineral investigations in the Valdez Creek Mining District, south-central Alaska: U.S. Bureau of Mines Open-File Report 1-92, 658 p., 2 sheets, scale 1:250,000. http:// dggs.alaska.gov/pubs/id/21306

Lande, L.L., 2016, A petrological model for the emplacement of the ultramafic Ni-Cu-PGE Alpha Complex, Eastern Alaska Range: Fairbanks, University of Alaska, M.Sc. thesis, 144 p.

LeBas, M.J., 2000, IUGS reclassification of the high-Mg and picritic volcanic rocks: Journal of Petrology, v. 41, p. 1,467-1,470.

Le Maitre, R.W., 1976, Some problems of the projection of chemical data into mineralogical classifications: Contributions to Mineralogy and Petrology, v. 56, p. 181-189.

Le Maitre, R.W., Bateman, P., Dudek, A., Keller, J., Lameyre, J., Le Bas, M.J., Sabine, P., Schmid,
R., Sorensen, H., Streckeisen, A., Woolley, A., and Zanettin, B., 1989, A classification of igneous rocks and glossary of terms, in, Le Maitre, R.W., ed., Recommendations of the International Union of Geological Sciences Subcommission on the Systematics of igneous rocks: Oxford, Blackwell, 193 p.

MacKevett, E.M., Cox, D.P., Potter, R.W. II, and Silberman, M.L., 1997, Kennecott-type deposits in the Wrangell Mountains, Alaska: High-grade copper ores near a basalt-limestone contact, in, Goldfarb, R.J., and Miller, L.D., eds., Economic Geology Monograph 9, p. 66-89.

Makarenko, Michael, Eggert, John, Simpson, R.G., Levy, Michael, Darling, George, 2015, Preliminary Economic Assessment Technical Report, Wellgreen Project, Yukon Territory, Canada: NI43-101 Technical Report prepared for Wellgreen Platinum. Report Date March 18, 2015.

Myers, Russell, Brown, Chris, Bovee, Joe, and Stein, Holly, 2015, Two ages of porphyry copper mineralization in the Slana region [abs.]: Alaska Miners Association convention, Anchorage, Alaska, November 1-7, 2015, p. 31-33.

Mooney, P.R., 2010, Geology of the Clearwater Mountains and the Southern Boundary of the Alaska Range Suture Zone: Davis, California: University of California, Davis, M.Sc. thesis, 93 p.

Newberry, R.J., and Twelker, Evan, 2016, Metallogeny and origins of $\mathrm{Cu}$-rich prospects in and near Nikolai Greenstone, Central Alaska [abs.]: Alaska Miners Association Biennial Mining Conference, Fairbanks, Alaska, April 4-9, 2016, p. 24-27.

Nickel Creek Platinum Corp., 2017, Nickel Shäw Project Mineral Resources, June 2017: http://www.nickelcreekplatinum.com/projects/ nickel-shaw/resource-estimate/default.aspx (as of October 31, 2018)

Nikogosian, I.K., and Sobolev, A.V., 1997, Ion-microprobe analysis of melt Inclusions in olivine: experience in estimating the olivine-melt partition coefficients of trace elements: Geochemistry International, v. 35, p. 119-126. 
Nokleberg, W.J., Aleinikoff, J.N., Bond, G.C., Ferrians, O.J., Jr., Herzon, P.L., Lange, I.M., Miyaoka, R.T., Richter, D.H., Schwab, C.E., Silva, S.R., Smith, T.E., and Zehner, R.E., 2015, Geologic maps of the eastern Alaska Range, Alaska (44 quadrangles, 1:63,360 scale), with descriptions and interpretations of map units: Alaska Division of Geological \& Geophysical Surveys Report of Investigation 2015-6, 64 p., 45 sheets, scale 1:63,360. http://doi.org/10.14509/29444

Nokleberg, W.J., Aleinikoff, J.N., Lange, I.M., Silva, S.R., Miyaoka, R.T., Schwab, C.E., and Zehner, R.E., 1992, Preliminary geologic map of the Mount Hayes Quadrangle, eastern Alaska Range, Alaska: U.S. Geological Survey Open-File Report 92-594, 39 p., 1 sheet, scale 1:250,000.

Nokleberg, W.J., Jones, D.L., and Silberling, N.J., 1985, Origin and tectonic evolution of the Maclaren and Wrangellia terranes, eastern Alaska Range, Alaska: Geological Society of America Bulletin v. 96, no. 10, p. 1,251-1,270.

O’Neill, J.M., Schmidt, J.M., and Cole, R.B., 2005, Cenozoic Intraplate tectonics-lithospheric right-lateral bulk shear deformation in the northern Talkeetna Mountains, south-central Alaska [abs.]: Geological Society of America Abstracts with Programs, v. 37, n. 7, paper no. 31-7.

Oswald, P.J., 2006, Eocene volcanic rocks of the southern Talkeetna Mountains, Alaska: anomalous forearc volcanism in an extensional setting: MS. Thesis, University of Idaho, $40 \mathrm{p}$.

Pearce, J.A., 2008, Geochemical fingerprinting of oceanic basalts with applications to ophiolite classification and the search for Archean oceanic crust: Lithos, v. 100, p. 14-48.

Price, J.B., 2004, Structural controls and stable isotope geochemistry of mineralization and wallrock alteration at the Bonanza mine, Kennecott, Alaska: Golden, Colorado School of Mines, M.Sc thesis, 211 p., 8 plates.

Pure Nickel Inc., 2013, Pure Nickel Inc. confirms extensive $\mathrm{Ni}-\mathrm{Cu}-\mathrm{Co}-\mathrm{PGE}$ mineralization on the MAN property, Alaska: News Release October 29, 2013 http://www.purenickel.com/s/News Releases.asp?ReportID=609291 (accessed October 31, 2018) 2014a, Pure Nickel Reports Favorable Results for Nickel Deportment Study at MAN Property: News Release April 22, 2014. http:// www.purenickel.com/s/NewsReleases.asp?Re portID=648641 (accessed October 31, 2018)

2014b, MAN Project overview: http://www. purenickel.com/s/MAN_Project.asp (accessed July 9, 2014)

Rogers, R.K., and Schmidt, J.M., 2003, Alaska Resource Data File, Talkeetna Mountains Quadrangle, Alaska: U.S. Geological Survey Open-File Report 2003-457, 293 p.

Rollinson, H.R., 1993, Using Geochemical Data: Evaluation, Presentation, Interpretation: Harlow, Essex, England, Pearson Education Limited, 352 p.

Rose, A.W., 1966, Geological and geochemical investigations in the Eureka Creek and Rainy Creek areas, Mt. Hayes Quadrangle, Alaska: Alaska Division of Mines and Minerals Geologic Report 20, 41 p., 3 sheets. http://doi.org/10.14509/349

Schmidt, J.M., Oswald, P.J., and Snee, L.W., 2002, The Deadman and Clark Creek fields-Indicators of early Tertiary volcanism in an extensional tectonic setting in the northern Talkeetna Mountains, Alaska: Geological Society of America Abstracts with Programs, v.34, no. 5, p. A-101.

Schmidt, J.M., and Rogers, R.K., 2007, Metallogeny of the Nikolai large igneous province (LIP) in southern Alaska and its influence on the mineral potential of the Talkeetna Mountains, in Ridgway, K.D., Trop, J.M., Glen, J.M.G., and O'Neill, J.M., eds., Tectonic growth of a collisional continental margin: Crustal evolution of southern Alaska: Geological Society of America Special Paper 431, p. 623-648.

Seraphim, R.H., 1975, Denali-A Nonmetamorphosed Stratiform Sulfide Deposit: Economic Geology, v. 70, p. 949-959.

Sicard, K.R., Twelker, Evan, Wypych, Alicja, Reioux, David, Freeman, L.K., Newberry, R.J., and Lande, L.L., 2015, Newly recognized strike-slip fault, shear zones, and associated metalliferous deposits in the Talkeetna Mountains, Alaska [abs.]: Geological Society of America Cordilleran Section - 111th Annual Meeting, Anchorage, Alaska, May 11-13, 2015, p. 50. 
Silberling, N.J., Richter, D.H., Jones, D.L., and Coney, P.C., 1981, Geologic map of the bedrock part of the Healy A-1 Quadrangle south of the Talkeetna-Broxson Gulch fault system, Clearwater Mountains, Alaska: U.S. Geological Survey Open-File Report 81-1288, 1 sheet, scale 1:63,360.

Stevens, D.L., 1971, Geology and geochemistry of the Denali Prospect, Clearwater Mountains, Alaska: Fairbanks, University of Alaska, Ph.D. dissertation, 81 p., illust., maps (4 folded), photos.

Storm, L.W.., 1919, Report on the King and Queen Group and the Sinclair and Foster Group, Talkeetna Mining District, Alaska: Unpublished report for Kennecott Mining Company, 12 p.

Stout, J.H., 1976, Geology of the Eureka Creek area, east-central Alaska Range: Alaska Division of Geological \& Geophysical Surveys Geologic Report 46, 32 p., 1 sheet, scale 1:63,360. http:// doi.org/10.14509/374

Sun S.-s., and McDonough, W.F., 1989, Chemical and isotopic systematics of oceanic basalts: implications for mantle composition and processes, in Saunders, A.D., and Norry, M.J., eds., Magmatism in the Ocean Basins: Geological Society Special Publication 42, p. 313-345.

Todd, Erin, Kylander-Clark, Andrew, Wypych, Alicja, Twelker, Evan, and Sicard, K.R., 2017, $\mathrm{U}-\mathrm{Pb}$ and $\mathrm{Lu}-\mathrm{Hf}$ isotope, age, and trace-element data from zircons at four sites in the western Alaska Range and Talkeetna Mountains, Alaska: Alaska Division of Geological \& Geophysical Surveys Raw Data File 2017-2, 7 p. http://doi. org/10.14509/29717

Trop, J.M. and Ridgeway, K.D., 2007, Mesozoic and Cenozoic tectonic growth of southern Alaska: A sedimentary basin perspective, in Ridgway, K.D., Trop, J.M., Glen, J.M.G., and O'Neill, J.M., eds., Tectonic growth of a collisional continental margin: Crustal evolution of southern Alaska: Geological Society of America Special Paper 431, p. 55-94.

Twelker, Evan, Bachmann, E.N., Freeman, L.K., Newberry, R.J., Reioux, D.A., Sicard, K.R., Tuzzolino, A.L., Wright, T.C., and Wypych, Alicja, 2014, Major-oxide, minor-oxide, and trace-element geochemical data from rocks and stream sediments in the Wrangellia mineral assessment area, Gulkana, Healy, Mount Hayes, and Talkeetna Mountains quadrangles, Alaska: Alaska Division of Geological \& Geophysical Surveys Raw Data File 2014-3, 6 p. http://doi. org/10.14509/27181

Twelker, Evan, Hubbard, T.D., Wypych, Alicja, Sicard, K.R., Newberry, R.J., Reioux, D.A., Freeman, L.K., and Lande, L.L., 2015a, Geologic map of the Talkeetna Mountains C-4 Quadrangle and adjoining areas, central Alaska: Alaska Division of Geological \& Geophysical Surveys Preliminary Interpretive Report 20156, 16 p., 1 sheet, scale 1:50,000. http://doi. org/10.14509/29470

Twelker, Evan, Waldien, T.S., Newberry, R.J., Freeman, L.K., Sicard, K.R., Lande, L.L., Wypych, Alicja, Reioux, D.A., and Bachmann, E.N., 2020, Bedrock geologic map of the eastern Denali Highway area, Mount Hayes, Healy, and Talkeetna Mountains quadrangles, Alaska: Alaska Division of Geological \& Geophysical Surveys Report of Investigation 2020-7. http://doi.org/10.14509/30469

Twelker, Evan, Newberry, R.J., Wypych, Alicja, Sicard, K.R., Reioux, D.A., Freeman, L.K., Lande, L.L., Blodgett, R.B., and Benowitz, J.A., 2015b, New Geologic Mapping in Western Wrangellia, Talkeetna Mountains, Alaska [poster]: Geological Society of America Cordilleran Section 111th Annual Meeting, Anchorage, Alaska, May 11-13, 2015, p. 53.

Twelker, Evan, and O'Sullivan, P.B., 2016, U-Pb zircon age data from meta-igneous rocks in the Clearwater Mountains, Mount Hayes A-6 Quadrangle, Alaska: Alaska Division of Geological \& Geophysical Surveys Raw Data File 20168, 17 p. http://doi.org/10.14509/29663

U.S. Geological Survey, 2018, Alaska Resource Data File (ARDF). Online link (https://ardf. wr.usgs.gov; updated March 2018).

Van Wyck, Nicolas, 2007, Annual Report on the Golddigger area, Talkeetna Mountains, Alaska: Unpublished report for Full Metal Minerals (U.S.A), 50 p. 
Waldien, T.S., 2015, Evolution of a range-boundary thrust in a strike slip fault system: The late Miocene-Recent slip history of the McCallum Creek fault, Eastern Alaska Range, Alaska: Davis, University of California, Davis, M.S. thesis, 118 p.

Waldien, T.S., and Roeske, S.M., 2017. Geologic Map of Broxson Gulch, eastern Alaska Range, Alaska. Geological Society of America Abstracts with Programs, v. 49, n. 6.

Wen, Hanjie; Zhu, Chuanwei; Zhang, Yuxu; Cloquet, Christophe; Fan, Haifeng; Fu, Shaohong, 2016, $\mathrm{Zn} / \mathrm{Cd}$ ratios and cadmium isotope evidence for the classification of lead-zinc deposits: Scientific Reports, v. 6.

Werdon, M.B., Azain, J.S., and Granitto, Matthew, 2014, Reanalysis of historical U.S. Geological Survey sediment samples for geochemical data from the western part of the Wrangellia terrane, Anchorage, Gulkana, Healy, Mt. Hayes, Nabesna, and Talkeetna Mountains quadrangles, Alaska: Alaska Division of Geological \& Geophysical Surveys Raw Data File 2014-5, 6 p. http://doi.org/10.14509/27287

Werdon, M.B., Riehle, J.R., Schmidt, J.M., Newberry, R.J., and Pessel, G.H., 2002, Geologic map of the Iron Creek area, Talkeetna Mountains B-5 Quadrangle, Alaska: Alaska Division of Geological \& Geophysical Surveys Preliminary Interpretive Report 2002-4, 1 sheet, scale 1:63,360. http://doi.org/10.14509/7144

Wilson, F.H., Hults, C.P., Mull, C.G., and Karl, S.M., 2015, Geologic map of Alaska: U.S. Geological Survey Scientific Investigations Map 3340, 197 p., 2 sheets, scale 1:1,584,000.

Wypych, Alicja, Twelker, Evan, Freeman, L.K., Lande, Lauren, Newberry, R.J., Reioux, D.A., and Sicard, K.R., 2014, Major-oxide and trace-element geochemical data from rocks collected in 2014 in the Wrangellia mineral assessment area, Talkeetna Mountains C-4, C-3, and B-4 quadrangles, Alaska: Alaska Division of Geological \& Geophysical Surveys Raw Data File 2014-22, 4 p. http://doi.org/10.14509/29140

2015, Major-oxide and trace-element geochemical data from rocks collected in 2015 in the Wrangellia mineral assessment area, Alaska: Alaska Division of Geological \& Geophysical Surveys Raw Data File 2015-16, 4 p. http://doi. org/10.14509/29518 


\section{APPENDIX: DESCRIPTIONS OF MINERAL OCCURRENCES}

This section describes mineral occurrences investigated by DGGS during fieldwork in 2013, 2014, and 2015. It is not an exhaustive list of occurrences in the study area. Locations are given in WGS 84 datum and were determined by handheld GPS with an estimated accuracy of $10 \mathrm{~m}$, except where noted. Abbreviations used below include parts per million (ppm), parts per billion (ppb), kilometer(s) $(\mathrm{km})$, meter $(\mathrm{s})(\mathrm{m})$, centimeter $(\mathrm{s})(\mathrm{cm})$, feet $(\mathrm{ft})$, township $(\mathrm{T})$, range $(\mathrm{R})$, and section $(\mathrm{sec}$.$) .$

\section{Unnamed (south tributary to Fog Creek)}

ARDF no.: Not previously documented

Latitude and longitude: $62.7179 \mathrm{~N}, 148.6000 \mathrm{~W}$

Location: The site is at an abandoned stream-cut bank about $400 \mathrm{~m}$ west of the center of sec. 6, T 30

N, R 5 E, Seward Meridian.

Main commodities: $\mathrm{Cu}$

Other commodities: Au, In, Mo

Ore minerals: Pyrite, chalcopyrite

Gangue minerals: Quartz, epidote

Geologic description: An isolated stream cut along a southern tributary to Fog Creek exposes altered and quartz-veined dacite porphyry in an outcrop over a distance of about $25 \mathrm{~m}$. The exposure exhibits widespread but low-intensity iron oxide staining, as well as secondary malachite on fracture surfaces (fig. A1A).

Primary mineralization is hosted by a network of randomly oriented, thin (3- to 10-mm-wide) quartz veinlets containing epidote, pyrite, and chalcopyrite (fig. A1B). Veinlet-selvage mineralogy includes epidote, chlorite, and very fine-grained chalcopyrite. Apart from veinlets, altered porphyry contains disseminated mineralization, with approximately 1 percent pyrite and trace chalcopyrite.

A select sample of quartz-pyrite veining assayed 0.79 percent copper, 0.164 ppm gold, 9.09 ppm indium, and 98.1 ppm molybdenum (sample 14ET332; Wypych and others, 2014), while a grab sample of altered porphyry without significant veining assayed 722 ppm copper (sample 14ET331; Wypych and others, 2014).

Altered dacite porphyry is sea green, and plagioclase and hornblende phenocrysts are heavily replaced by a propylitic assemblage including abundant epidote and lesser chlorite (fig. A1C).

We infer the age of intrusion and mineralization to be latest Cretaceous to Paleocene, based on compositional and textural similarities to a dacite porphyry intrusion $32 \mathrm{~km}$ to the south, which yielded a $67.1 \pm$ 0.9 Ma, ${ }^{40} \mathrm{Ar} /{ }^{39} \mathrm{Ar}$ biotite plateau age (Benowitz and others, 2015; Twelker and others, 2015a). Granodiorite plutons $15 \mathrm{~km}$ to the west have ${ }^{40} \mathrm{Ar} /{ }^{39} \mathrm{Ar}$ plateau ages of $68.8 \pm 0.6 \mathrm{Ma}$ (hornblende) and $60.4 \pm 0.3 \mathrm{Ma}$ for biotite (Benowitz and others, 2015) and could represent the same intrusive suite but reflecting a greater depth of erosion. Based on correlation with its closest outcrops, and interpretation of airborne geophysical data (Burns and others, 2014a, b), the dacite porphyry hosting this mineral occurrence is inferred to intrude metasedimentary rocks of the Kahiltna assemblage (Twelker and others, 2015a).

Alteration of deposit: The occurrence is characterized by a propylitic assemblage of epidote, chlorite, and pyrite.

Mineral deposit model: Porphyry Cu-Mo(?) (Cox and Singer, 1986; model 21a)

Age of mineralization: Latest Cretaceous to Paleocene, based on correlation with dacite porphyry intrusions $32 \mathrm{~km}$ to the south $(67.1 \pm 0.9 \mathrm{Ma}$; biotite) and granodiorite plutons $15 \mathrm{~km}$ to the west (Benowitz and others, 2015).

Exploration history: Sampling by the Alaska Division of Geological \& Geophysical Surveys (Wypych and others, 2014). 

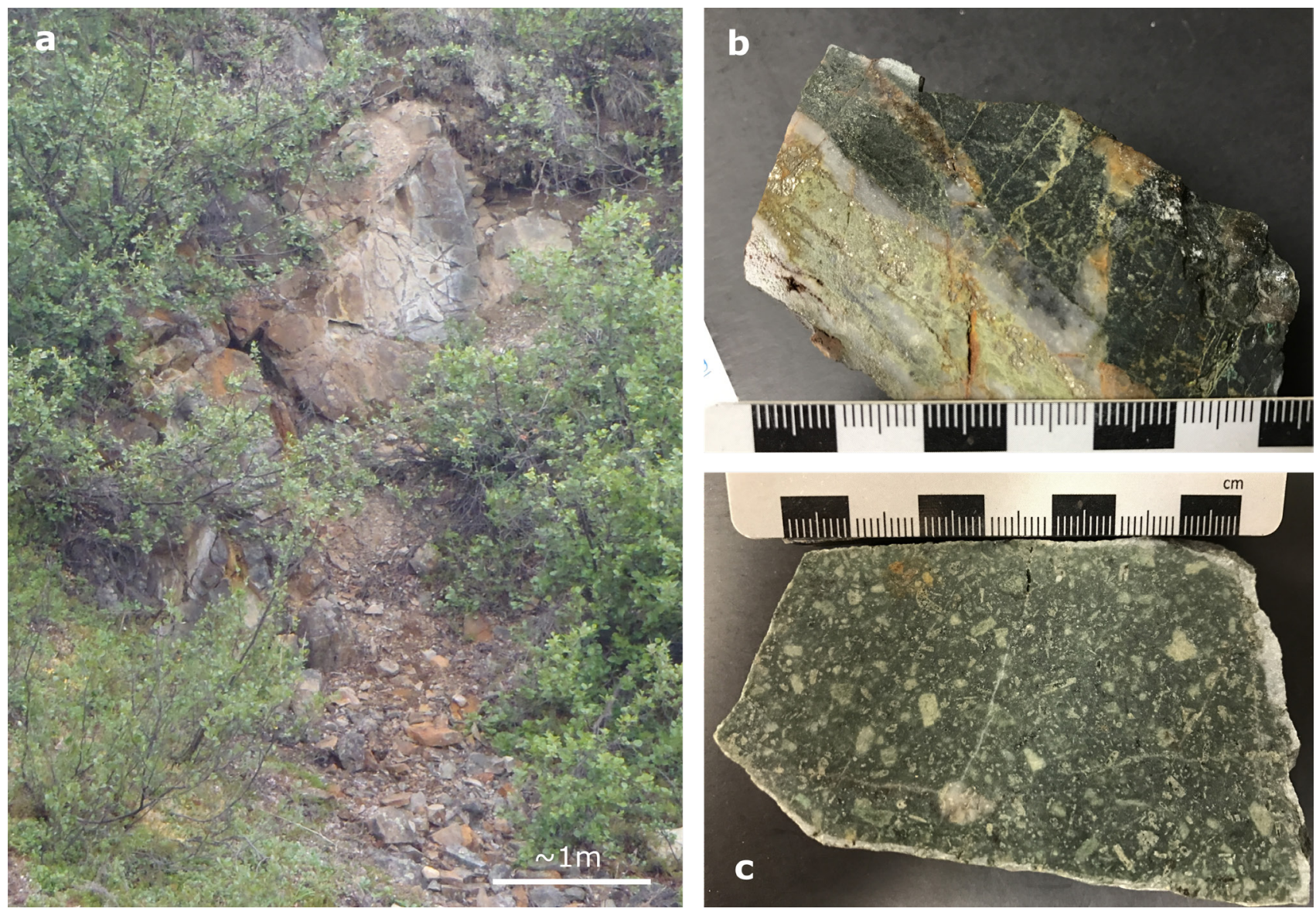

Figure A1. Mineralization at site 1 (Unnamed_south tributary to Fog Creek; see fig. 4). A. Oblique photo, looking west, of outcrop showing randomly oriented veinlets at center top, and iron staining at center left and in talus. B. quartz-epidotepyrite-chalcopyrite veinlet cutting altered dacite porphyry (14ET332). C. propylitic-altered dacite porphyry (14ET331). Major divisions of scale in $(\mathbf{B})$ and $(\mathbf{C})$ are in centimeters.

\section{Unnamed (north of Peak 6910)}

ARDF no.: Not previously documented

Latitude and longitude: $62.5922 \mathrm{~N}, 148.4972 \mathrm{~W}$

Location: The site is about 400 m north of the center of sec. 22, T 29 N, R 5 E, Seward Meridian, and $1.3 \mathrm{~km}$ west-northwest of Peak 6910 in the Talkeetna Mountains C-3 Quadrangle.

Main commodities: Au

Ore minerals: Iron sulfides (boxwork)

Gangue minerals: Quartz

Geologic description: A gold-bearing quartz vein up to 80 -cm thick is exposed over $10 \mathrm{~m}$ of glacially scoured outcrop (fig. A2); the vein strikes 141 degrees azimuth and dips 86 degrees towards the southwest. The vein comprises vitreous to milky quartz that is locally vuggy or druzy, with minor seams of chlorite and ferroan dolomite. About 1 percent iron oxide boxwork within the vein presumably reflects weathered iron sulfides. Greenstone country rock immediately adjacent to the vein contains about 1 percent disseminated pyrrhotite.

A select sample of rusty weathering, vuggy, and sheared vein material assayed $0.875 \mathrm{ppm}$ gold, with significantly anomalous W (54.6 ppm), Bi (23.3 ppm), and Te (15.8 ppm) (sample 14LF280A; Wypych and others, 2014). 
The vein is hosted by Late Triassic Nikolai Greenstone (Twelker and others, 2015a) and could be related to any one of several Jurassic through Paleogene intrusive, structural, or metamorphic events.

Alteration of deposit: Chlorite and ferroan dolomite

Mineral deposit model: Low-sulfide Au-quartz vein (Cox and Singer, 1986; model 36a)

Age of mineralization: Post-Late Triassic Exploration history: Sampling by the Alaska Division of Geological \& Geophysical Surveys (Wypych and others, 2014).

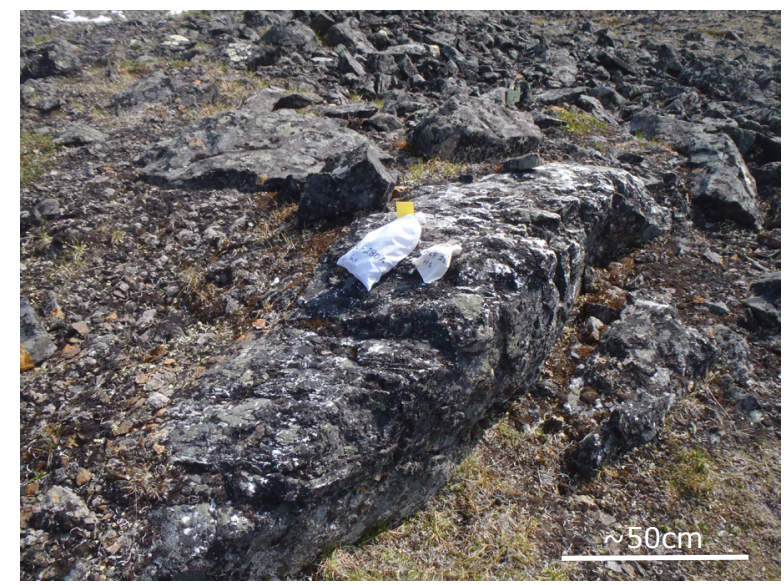

Figure A2. Outcrop exposure of the quartz vein occurrence at site 2 (Unnamed — north of Peak 6910; fig. 4). The maximum horizontal width of the vein is $80 \mathrm{~cm}$.

\section{Unnamed (north of Peak 6545)}

ARDF no.: Not previously documented Latitude and longitude: $62.5690 \mathrm{~N}, 148.5275 \mathrm{~W}$

Location: The site is approximately $1.1 \mathrm{~km}$ north of Peak 6545 in the Talkeetna Mountains C-4 Quadrangle, on the ridgeline at an elevation of 5,600 ft. It lies approximately $0.6 \mathrm{~km}$ south-southwest of the center of sec. 28, T 29 N, R 5 E, Seward Meridian.

Main commodities: $\mathrm{Cu}$

Other commodities: $\mathrm{Au}, \mathrm{Ag}$

Ore minerals: Chalcopyrite, pyrite, bornite

Gangue minerals: Clinopyroxene, garnet, amphibole

Geologic description: A pyrite-rich, amphibole-altered sedimentary layer is about $1 \mathrm{~m}$ thick, and continues across the outcrop for at least $4 \mathrm{~m}$. A second layer, also about $1 \mathrm{~m}$ thick, consists of fine-grained, pale-green, skarn-like calc-silicate rock with minor garnet. The remainder, about 80 percent of the exposure, is unaltered gabbro.

A sample of the pyrite-rich layer assayed 3.82 percent copper, 1.29 ppm gold, and 24.2 ppm silver, while a sample of the skarn-like layer assayed 1.03 percent copper, $0.595 \mathrm{ppm}$ gold, and $17.55 \mathrm{ppm}$ silver (samples 13RN503A and 13RN503B, respectively; Twelker and others, 2014a).

This mineral occurrence is hosted by interlayered metasedimentary rocks and gabbro, hornblendite, and diorite intrusions near the margin of a Middle Jurassic granodiorite pluton (fig. 4; Twelker and others, 2015a). We interpret the age of the occurrence to be Middle Jurassic based on its close proximity to the granodiorite pluton, as well as an ${ }^{40} \mathrm{Ar} /{ }^{39} \mathrm{Ar}$ age of $165.2 \pm 2.1 \mathrm{Ma}$ for alteration-related calcic clinoamphibole collected at this occurrence (Benowitz and others, 2014).

Mineral deposit model: Possible Cu skarn of Cox and Singer (1986; model 18b)

Alteration of deposit: Calc-silicate minerals, including amphibole and garnet Age of mineralization: Middle Jurassic, based on proximity to the nearby pluton of that age, as well as on an ${ }^{40} \mathrm{Ar} /{ }^{39} \mathrm{Ar}$ age of $165.2 \pm 2.1 \mathrm{Ma}$ for alteration-related amphibole collected at this occurrence (Benowitz and others, 2014).

Exploration history: Sampling by the Alaska Division of Geological \& Geophysical Surveys (Twelker and others, 2014a). 


\section{Unnamed (southwest of Peak 6086)}

ARDF no.: Not previously documented

Latitude and longitude: $62.5583 \mathrm{~N}, 148.6275 \mathrm{~W}$

Location: The site is approximately $1.6 \mathrm{~km}$ south-southwest of Peak 6086 in the Talkeetna Mountains C-4 Quadrangle, near the center of sec. 36, T 29 N, R 4 E, Seward Meridian.

Main commodities: $\mathrm{Cu}$

Other commodities: Au

Ore minerals: Chalcopyrite, magnetite

Gangue minerals: Garnet(?), tremolite

Geologic description: Skarn mineralization occurs locally in float along the contact between a granodiorite pluton and marble (fig. 4) over a distance of about $300 \mathrm{~m}$. The skarn consists of bands of fine- to coarsegrained (up to $1.5 \mathrm{~cm}$ long) tremolite, up to 80 percent magnetite, minor garnet(?), and disseminated chalcopyrite. Malachite coats fractures. Assays of select samples carried 0.66 percent copper and $0.133 \mathrm{ppm}$ gold (14LF038), and 0.745 percent copper and 0.76 ppm gold (14LF035; Wypych and others, 2014).

We interpret the mineralization to be of Jurassic age based on its spatial proximity to the Jurassic granodiorite. The host marble is tentatively assigned to be Late Triassic based on its contact relationships with the Nikolai Greenstone (Twelker and others, 2015a).

Alteration of deposit: Calc-silicate skarn mineralogy, including tremolite and possible garnet Mineral deposit model: Possibly Cu skarn of Cox and Singer (1986; model 18b)

Age of mineralization: Middle Jurassic, ca. $168 \mathrm{Ma}$, based on ${ }^{40} \mathrm{Ar} /{ }^{39} \mathrm{Ar}$ dating reported for the pluton by Benowitz and others (2015).

Exploration history: Sampling by the Alaska Division of Geological \& Geophysical Surveys (Wypych and others, 2014).

\section{Unnamed (at Peak 6045)}

ARDF no.: Not previously documented

Latitude and longitude: $62.5553 \mathrm{~N}, 148.5740 \mathrm{~W}$

Location: The site is at an elevation of approximately 6,200 ft, $900 \mathrm{~m}$ north of Peak 6045 in the Talkeetna Mountains C-4 Quadrangle. It is in the SW11/4 of sec. 32, T 29 N, R 5 E, Seward Meridian.

Main commodities: Mo

Other commodities: $\mathrm{Cu}$

Ore minerals: Chalcopyrite, molybdenite, pyrite

Gangue minerals: Quartz

Geologic description: A northeast-trending zone of sheeted quartz veins and iron oxide staining is exposed over a thickness of approximately $10 \mathrm{~m}$ and a strike length of $100 \mathrm{~m}$ (fig. A3A). Helicopter reconnaissance suggests the iron staining may continue an additional $300 \mathrm{~m}$ along trend to the northeast.

Within the iron-oxide-stained zone, a series of parallel quartz veinlets 1 to $5 \mathrm{~cm}$ thick cut granodiorite. Faulting and shearing are also evident within the zone; both veins and fault surfaces have northeasterly strikes and subvertical dips (fig. A3B). Vein quartz is fine grained, milky white to gray, and contains minor pyrite and trace chalcopyrite and molybdenite. Veinlet margins contain disseminated pyrite and exhibit selective alteration of plagioclase to K-feldspar; hornblende is moderately chloritized.

Select sampling of vein material yielded 1,090 ppm molybdenum and 198 ppm copper (14ET032; Wypych and others, 2014); a wallrock-rich sample yielded $63.2 \mathrm{ppm}$ molybdenum and 527 ppm copper (14ET033; Wypych and others, 2014). 
This occurrence is hosted by Jurassic granodiorite (fig. 4; Twelker and others, 2015a). The age of mineralization may be Middle Jurassic if it is of magmatic origin. However, due to the structural nature of the occurrence and its parallelism and proximity to the Central Raingellia fault zone $(1 \mathrm{~km}$ to the northwest; Twelker and others, 2015a), it may be more likely that the mineralization occurred with major fault activity during the Paleogene.

Alteration of deposit: Weak potassic alteration surrounds veinlets.

Mineral deposit model: Unknown

Age of mineralization: Likely Paleogene, based on probable association with nearby faulting; possibly Middle Jurassic.

Exploration history: Sampling by the Alaska Division of Geological \& Geophysical Surveys (Wypych and others, 2014).
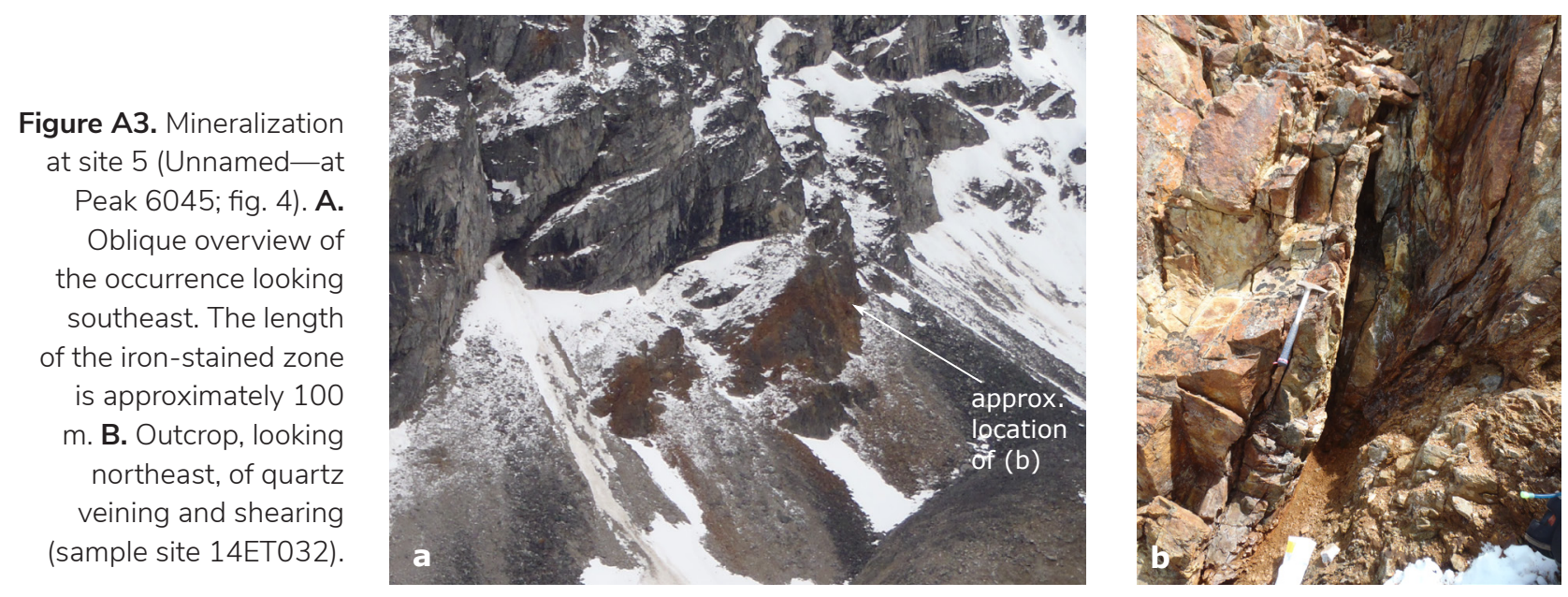

\section{Unnamed (north of Talkeetna River) (TK053)}

This record is a revision of TK053.

ARDF no.: TK053

Latitude and longitude: $62.5040 \mathrm{~N}, 148.7154 \mathrm{~W}$

Location: The site is at an elevation of about $2,800 \mathrm{ft}, 1.6 \mathrm{~km}$ north of the Talkeetna River, near the center of the NE1/4 of sec. 21, T 28 N, R 4 E, Seward Meridian. This is locality 45 of Csejtey and Miller, 1978.

Main commodities: $\mathrm{Cu}$

Other commodities: Ag

Ore minerals: Bornite, chalcocite, malachite

Geologic description: This occurrence consists of a small brecciated shear zone cutting Late Triassic Nikolai Greenstone (upper member; Twelker and others, 2015a). The occurrence is approximately $1 \mathrm{~m}$ thick and is exposed over an outcrop length of approximately $10 \mathrm{~m}$. Veinlets of presumably hypogene bornite less than $1 \mathrm{~cm}$ thick infill some shear surfaces, and supergene deposits of malachite, chalcocite, and limonite coat parts of the outcrop (fig. A4). Measured shear surfaces are subvertical and have an average strike of 32 degrees azimuth.

Selective samples of mineralization at this occurrence assayed 19.65 percent copper and $41.7 \mathrm{ppm}$ silver (14ET178), and 13.5 percent copper and 48.4 ppm silver (14AW109; Wypych and others, 2014).

The occurrence is hosted by the Late Triassic Nikolai Greenstone (upper member, kn2), and is proximal and subparallel to strands of the Central Raingellia fault of Twelker and others (2015a). Crosscutting 
relationships with Paleogene volcanic rocks to the south indicate that most activity on this structure occurred during the Eocene; on this basis, we infer that mineralization occurred during Eocene tectonics and regional magmatism.

Mineral deposit model: Basaltic $\mathrm{Cu}(?)$ (Cox and Singer, 1986; model 23?)

Age of mineralization: Mineralization is likely Eocene, based on its association with the nearby Raingellia fault of Twelker and others (2015a).

Exploration history: The U.S. Geological Survey and the Alaska Division of Geological \& Geophysical Surveys have sampled the occurrence (Csejtey and Miller, 1978; Wypych and others, 2014).

Figure A4. Malachite-stained shear surfaces cutting metabasalt at site 6 (Unnamed-north of Talkeetna River; fig. 4). Bright orange lichen coats the outcrop in the vicinity of copper mineralization. Hammer is $40 \mathrm{~cm}$ long.

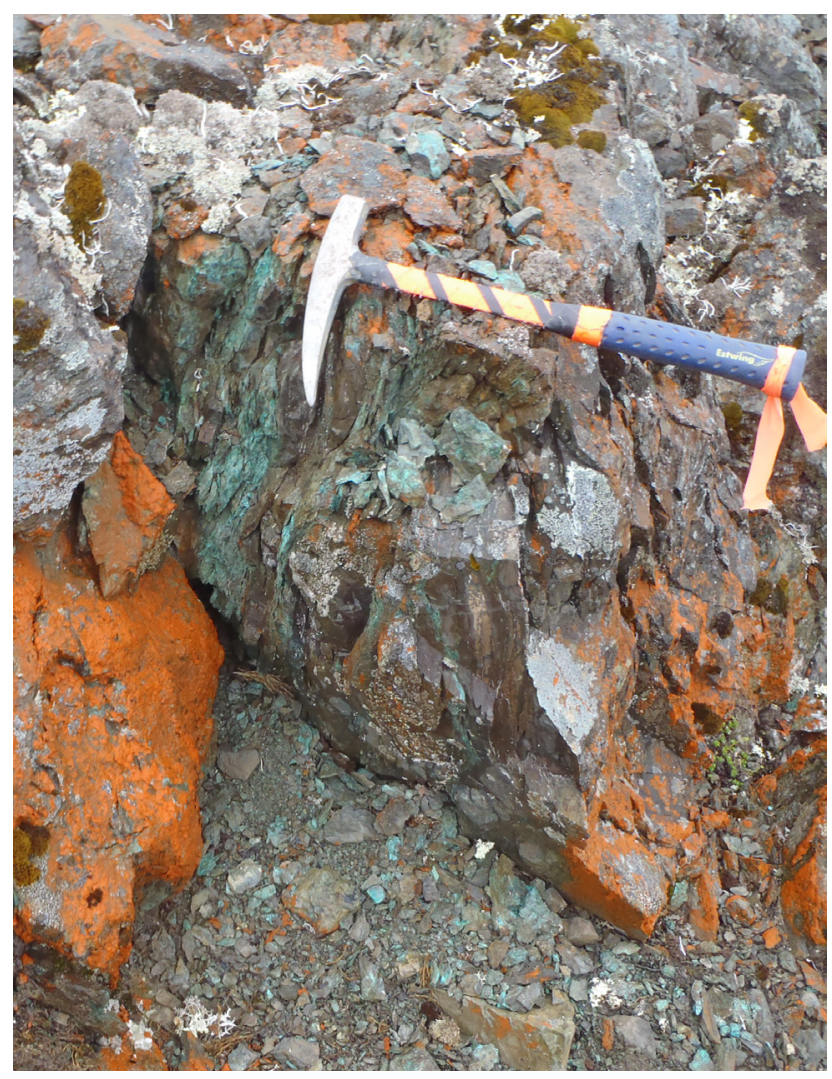

\section{Red Ridge (TK091)}

ARDF no.: TK091

Latitude and longitude: $62.5063 \mathrm{~N}, 148.5885 \mathrm{~W}$

Location: The prospect is located in the NE1/4 of sec. 19, T 28 N, R 5 E, Seward Meridian. This location is of an altered and weakly mineralized outcrop near the center of the 5-km-long iron-stained zone.

Main commodities: Au

Other commodities: $\mathrm{Cu}, \mathrm{Zn}$

Ore minerals: Pyrite, chalcopyrite

Gangue minerals: Sericite

Geologic description: This occurrence has several styles of mineralization that are likely unrelated. The name "Red Ridge" presumably refers to the prominent 5-km-long, 500-m-wide iron oxide color anomaly, which trends northeast across several ridges in the vicinity of this occurrence (fig. A5). The source of the color anomaly is albite-epidote-quartz-white mica schist, which typically contains 2-5 percent disseminated pyrite and trace chalcopyrite. Fourteen samples collected by the Alaska Division of Geological \& Geophysical Surveys (DGGS) in 2014 contain maximum values of 331 ppm copper, 483 ppm zinc, and $59 \mathrm{ppb}$ gold. However, selenium averaged $13 \mathrm{ppm}$, with a maximum value of $74 \mathrm{ppm}$, and rhenium averaged $65 \mathrm{ppb}$, with a maximum value of $326 \mathrm{ppb}$ (Wypych and others, 2014). Anderson (1969) reported values of up to $1.26 \mathrm{ppm}$ gold and $9.5 \mathrm{ppm}$ silver in greenstone, and $0.44 \mathrm{ppm}$ gold in siltstone along part of the iron-stained trend; DGGS did not revisit these locations during 2014.

Despite high silica values and light color, concentrations of $\mathrm{TiO}_{2}$ and $\mathrm{Zr}$ indicate the protolith of the host rock for this mineral occurrence is chemically more similar to mafic- to intermediate-metavolcanic rocks or metasedimentary rocks than to felsic metavolcanic rocks in the area. Locally observed Cr-bearing mica, and gradational transitions between this unit and mafic metavolcanic rocks, support the interpre- 


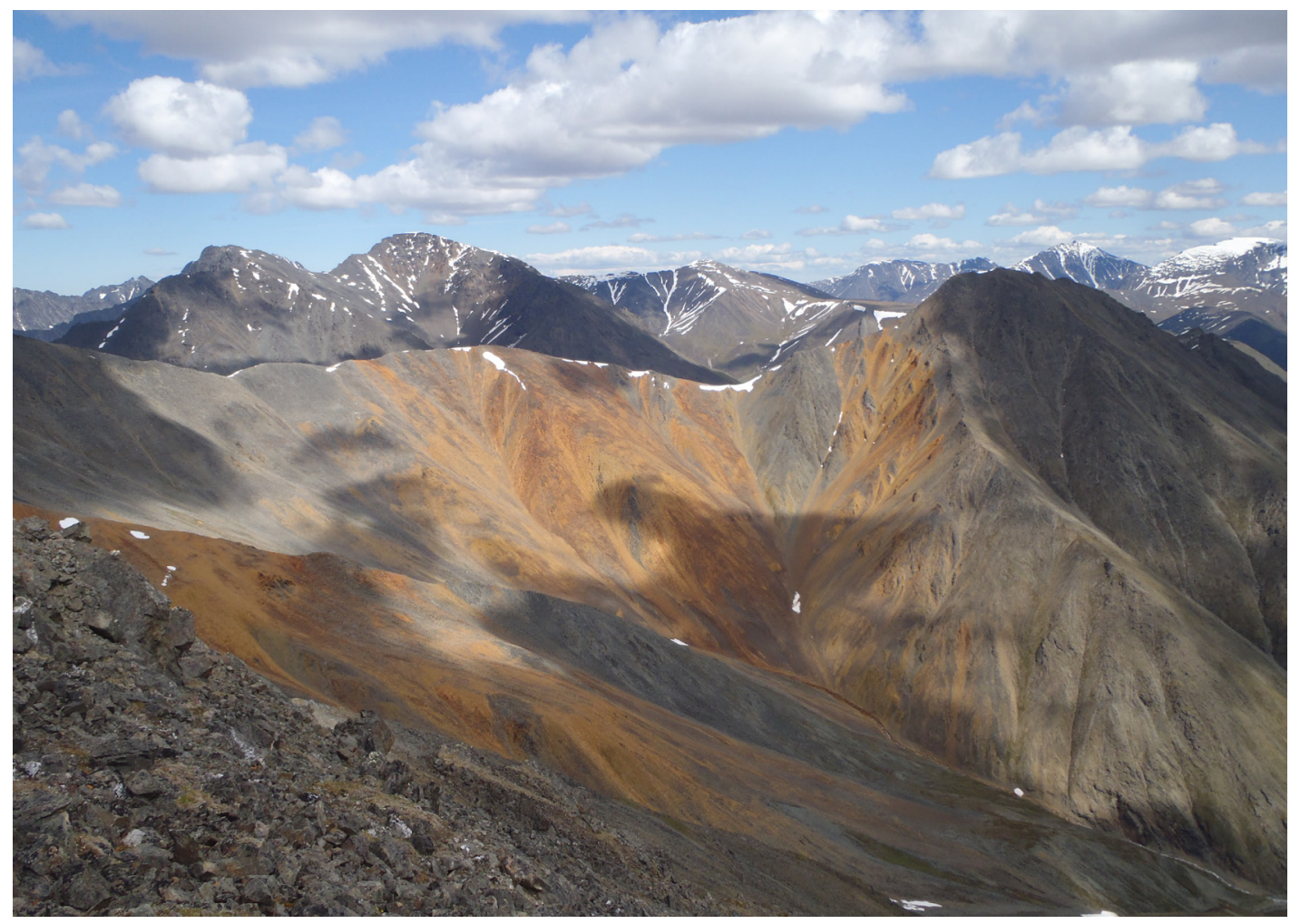

Figure A5. North-facing oblique view of part of the Red Ridge occurrence (site 7; fig. 4). VABM Jaina is just out of view at left; Peak 5833 is seen at the right side of the photo.

tation that this unit represents a quartz-sericite-pyrite-style alteration product of mafic rocks (Twelker and others, 2015a). White micas form a metamorphic fabric, and ${ }^{40} \mathrm{Ar} /{ }^{39} \mathrm{Ar}$ dating yielded a plateau age of $186.3 \pm 0.8 \mathrm{Ma}$ that is similar to the $195 \mathrm{Ma}$ metamorphic cooling age of nearby amphibolite (Benowitz and others, 2015). We interpret the quartz-sericite-pyrite alteration and accompanying geochemical anomalies to have formed in a pre- to syn-metamorphic setting, probably either accompanying Pennsylvanian to Permian volcanism or plutonic activity during the Early Jurassic.

Structurally controlled mineralization, interpreted to be later and post-metamorphic, also occurs in the Red Ridge area. This mineralization is adjacent to, and possibly associated with, a Paleogene porphyry dike; a chalcopyrite-bearing quartz vein 30 to $40 \mathrm{~cm}$ thick assayed $893 \mathrm{ppm}$ copper (sample 14ET098; Wypych and others, 2014). Anderson (1969) reports quartz vein material grading $0.44 \mathrm{ppm}$ gold, and fault-gouge material containing 1,600 ppm copper.

Mineral deposit model: Metamorphosed quartz-sericite-pyrite alteration zone crosscut by postmetamorphism polymetallic veins

Alteration of deposit: The occurrence is characterized by widespread pre-metamorphic quartzsericite-pyrite-type alteration.

Age of mineralization: Alteration zone is pre-metamorphism (Pennsylvanian to Early Jurassic); polymetallic veinlets may be Paleogene.

Exploration history: In the 1970's, the Red Ridge 1 to 82 lode claims were staked by Cities Service Minerals Company. Exploration by Cities Service Minerals Company included ground magnetics, EM and IP geophysical surveys, and excavation of two trenches (Don Stevens, written commun., 1992; cited by Rogers and Schmidt, 2003). MMG USA Exploration LLC staked the occurrence during a regional nickel-focused reconnaissance program in 2013; as of January 2017, no valid claims were present. 


\section{King and Queen}

\section{ARDF no.: TK088}

Latitude and longitude: $62.4792 \mathrm{~N}, 148.7885 \mathrm{~W}$

Location: The King and Queen prospect is at an elevation of about 3,900 ft on a light-colored, domelike hill; it is about $3.2 \mathrm{~km}$ south of the Talkeetna River and about $0.6 \mathrm{~km}$ north of the center of sec. 31 , T 28 N, R 4 E, Seward Meridian. This location is of a trench in the central prospect area.

Main commodities: Au

Other commodities: Ag, $\mathrm{Hg}$

Geologic description: The following is adapted from Ben Porterfield (written commun., 2013):

The prospect is hosted by a sequence of Eocene volcanic rocks including lower basaltic and andesitic flows and an upper sequence of alternating andesitic flows, pyroclastic rocks, and felsic tuffs and flows. These rocks are intruded by rhyolite and dacite dikes, sills, and small domes and by minor basaltic dikes.

Low sulfidation-type gold and silver mineralization is hosted by devitrified and illite-altered volcanic rocks, primarily pyroclastic rocks and felsic tuffs and flows. No significant quartz veining or silicification has been observed, and only minor disseminated pyrite is found in mineralized rocks. Base metals and all trace elements except mercury are not significantly anomalous.

The historic, high-grade gold and silver assays came from "seams" exposed in prospect trenches, indicating the mineralization is hosted by altered fracture zones and not by veins or silicification. Kennecott geologist L.W. Storm, who visited the property in 1919, took samples from prospect trenches, which included 25 feet grading 0.08 ounce of gold per ton and 2.9 ounces of silver per ton. Modern shallow trenches in clay rich colluvium on top of the hill include a 58-ft-long trench, which assayed an average of 0.053 ounce of gold per ton. Samples from the margins of the dome contained up to 12 parts per million mercury.

Grab samples of altered and brecciated material collected by the Alaska Division of Geological \& Geophysical Surveys range from 0.022 to 0.625 ppm gold, with insignificant silver and base metals (Wypych and others, 2014); "seam"-type mineralization was not sampled.

The prospect lies near strands of the Central Raingellia fault of Twelker and others (2015a). That, as well as association of gold with structures ("seams") at this prospect, suggests a possible age and genetic association with this Eocene structure.

Mineral deposit model: Epithermal gold

Alteration of deposit: Low-intensity illite and calcite alteration of volcanic rocks; chalcedonic quartz and propylitic alteration

Age of mineralization: Eocene, based on the age of the host volcanic rocks, associated intrusions, and activity on nearby structures (Twelker and others, 2015a).

Exploration history: Prospectors Sinclair and Foster staked the King and Queen group claims, which were evaluated by Kennecott geologist L.W. Storm in 1919. A shallow, timber-cribbed shaft, hand trenches, and a cabin existed at the time of Storm's evaluation. Full Metal Minerals Inc. mapped and sampled the prospect area under option from Ben Porterfield during 2006. 


\section{Sinclair and Foster (Little Vein, Canyon)}

This site was described by Storm (1919) and Van Wyck (2007); it was not directly investigated by DGGS during this program. It was previously incorporated into the ARDF record for King and Queen (TK088).

ARDF no.: Not previously documented Latitude and longitude: $62.4493 \mathrm{~N}, 148.7017 \mathrm{~W}$

Location: The site is in a small canyon in the NW1/4 of sec. 10, T 27 N, R 4 E, Seward Meridian. The site location was determined by handheld GPS.

Main commodities: Au

Ore minerals: Pyrite

Geologic description: Kennecott geologist L.W. Storm first reported on this occurrence, which was submitted by two prospectors named Sinclair and Foster. An irregular mass of porphyry or similar rocks is exposed along a length of $350 \mathrm{ft}$ in the canyon of Gold Creek; the rocks in this area are cut by small seams or crevices 0.5 to 6 inches in width. Careful scraping of these seams yielded material with assays ranging from trace to 6.8 ounces of gold per ton and 15.9 ounces of silver per ton. A broader, 22-ft-long interval between seams yielded 0.02 ounce of gold per ton and trace silver (Storm, 1919). The high silver assays indicate the gold values are not related to placer contamination (Ben Porterfield, written commun., 2013).

Geologist Nicholas Van Wyck and Full Metal Minerals Inc. relocated the prospect in 2006 and confirmed Storm's description of gold-bearing, clay-bearing seams. Petrographic work shows the country rock is quartz-sericite-pyrite-calcite-altered Eocene lithic tuff and carries anomalous gold. Grid sampling by Full Metal over a 60-m length of the canyon resulted in a roughly 20-m-wide zone (5 samples) assaying greater than $0.1 \mathrm{ppm}$ gold, with a maximum value of $0.292 \mathrm{ppm}$ gold and $5.7 \mathrm{ppm}$ silver (Van Wyck, 2007).

The site lies $1 \mathrm{~km}$ northwest of a major northeast-trending high-angle structure that juxtaposes Eocene volcanic rocks against Paleozoic mafic metavolcanic rocks (Twelker and others, 2015a).

Mineral deposit model: Epithermal gold Alteration of deposit: Quartz-sericite-pyrite alteration of volcaniclastic host rocks Age of mineralization: Likely Eocene, based on associated volcanic rocks, intrusions, and regional tectonic activity.

Exploration history: Prospectors Sinclair and Foster staked two claims at this occurrence ("Sinclair" and "Foster"). Kennecott geologist L.W. Storm examined the claims in 1919 during his evaluation of Sinclair and Foster's other property, King and Queen. A cabin existed near King and Queen, where shallow trenches were dug prior to the 1919 evaluation. The prospect was later relocated by Full Metal Minerals Inc. in 2006. 


\section{Unnamed (at Peak 5380)}

ARDF no.: Not previously documented

Latitude and longitude: $62.3535 \mathrm{~N}, 148.9800 \mathrm{~W}$

Location: The site is in the SW1/4 of sec. 7, T 26 N, R 3 E, Seward Meridian, about 300 m eastnortheast of Peak 5380 in the Talkeetna Mountains B-4 Quadrangle.

Main commodities: $\mathrm{Sb}$, As

Ore minerals: Pyrite, stibnite(?), arsenopyrite(?)

Gangue minerals: Quartz

Geologic description: Silicified and mineralized tectonic breccia is exposed within the deformation zone of the Central Raingellia fault of Twelker and others (2015a). Breccia clasts are chiefly siliceous mylonite, angular, and range from rock flour to cobble size. The breccia is mostly clast-supported, or clasts are supported in silicified rock flour. Breccia matrix contains about 5 percent very fine grained (0.1-mm-diameter) pyrite; samples assayed 186-250 ppm antimony and 1,020-2,070 ppm arsenic, but no anomalous gold (samples 14LF218 and 14LF219; Wypych and others, 2014). The breccia is exposed in two outcrops that indicate minimum thicknesses of $1-2 \mathrm{~m}$ and $6 \mathrm{~m}$. Brecciated mylonite borders the occurrence immediately to the northwest.

Mineral deposit model: Antimony-arsenic-mineralized tectonic breccia

Alteration of deposit: Silicification

Age of mineralization: Possibly Eocene, based on the age of major activity on the Central Raingellia fault (Twelker and others, 2015a).

Exploration history: Sampling by the Alaska Division of Geological \& Geophysical Surveys (Wypych and others, 2014).

\section{Butte Creek intrusive complex (Peak 5532 lode occurrence)}

\section{ARDF no.: HE159}

Latitude and longitude: $63.0066 \mathrm{~N}, 147.7523 \mathrm{~W}$

Location: The occurrence is located on the ridge and slope west and north of Peak 5532 in the Healy A-2 Quadrangle, near the center of sec. 16, T 22 S, R 1 W, Fairbanks Meridian.

Main commodities: $\mathrm{Cu}, \mathrm{Ni}, \mathrm{Pt}, \mathrm{Pd}$

Other commodities: $\mathrm{Cr}$

Ore minerals: Chalcopyrite, pentlandite, pyrrhotite, chromite

Geologic description: A multiphase gabbroic to ultramafic sill complex (Butte Creek intrusive complex [BCI]) intrudes hornfelsed Permian to Triassic sedimentary rocks of the Wrangellia terrane. The northeaststriking sill complex is approximately $23 \mathrm{~km}$ long, and at Peak 5532 at least $700 \mathrm{~m}$ thick. Hornfels bedding dips 35-45 degrees to the southeast; igneous layering is subparallel, dipping 30-35 degrees to the southeast.

At the Peak 5532 location, the Butte Creek intrusive complex consists of an uppermost series of sills of cliff-forming gabbronorite approximately $350 \mathrm{~m}$ thick, which caps the hill (figs. A6, A7). Below this, the complex comprises olivine cumulates (olivine gabbro, troctolite, and plagioclase wehrlite) with a total thickness of approximately $350 \mathrm{~m}$, excluding a hornfels layer near the base. Modal olivine generally increases towards the center of this body, ranging from about 5 percent near the top and base, up to 75 percent near the center (fig. A7). It is unclear whether this variation occurs gradationally or across multiple unrecognized internal sill contacts. Intercumulus phlogopite occurs as a minor phase in some of the ultramafic rocks; dating of phlogopite indicates a Late Triassic magmatic age of $225.8 \pm 1.1 \mathrm{Ma}\left({ }^{40} \mathrm{Ar} /{ }^{39} \mathrm{Ar}\right.$ plateau age; Benowitz and others, 2014).

Numerous thin bodies of leucogabbro occur within this unit, visible as white bands in figure A6. Many 
of these are subparallel to sill contacts and give the impression of magmatic layering; however, others show crosscutting relationships (fig. A6, insets A, B), suggesting they are a late-forming dike-sill system.

Olivine compositions from the olivine-rich troctolite fall into two groups. The bulk of the complex has forsterite (Fo) 77.6 to 82.1 with 742 to $1,397 \mathrm{ppm}$ nickel. A more primitive sample, likely a separate sill, has olivine averaging $\mathrm{Fo}_{84}$ and 2,870 ppm nickel (see table 1). Clinopyroxenes are diopside, with $\mathrm{Mg}$ numbers (100 $\mathrm{x}$ molar magnesium / [magnesium + iron]) ranging from 84.8 to 90.1 (table 2). Both olivine and clinopyroxene values are consistent with crystallization from a normal basaltic magma such as the Nikolai Greenstone.

Microprobe examination of samples from the olivine-rich troctolite unit shows magmatic sulfide grains consisting of intergrown pyrrhotite, pentlandite, and, locally, chalcopyrite occurring at grain boundaries (fig. A8A). Additionally, spherical inclusions of intergrown pyrrhotite and pentlandite within olivine (fig. A8B, inset) apparently represent magmatic sulfide melt inclusions. Both observations indicate that a magmatic sulfide melt separated from silicate melt prior to full crystallization of cumulate olivine in the intrusion, and that at least some of the nickel reported in assays occurs as sulfide rather than nickel held within silicate minerals.

Samples taken from the Butte Creek intrusive complex contain anomalous but low concentrations of copper, nickel, platinum, and palladium associated with both the mafic cumulates (troctolite, olivine gabbro, plagioclase wehrlite) and the crosscutting gabbroic sills and dikes. The U.S. Bureau of Mines (Balen, 1990; Kurtak and others, 1991) sampled troctolite containing 501 ppm nickel, 219 ppm copper, 140 ppb platinum, and $16 \mathrm{ppb}$ palladium, as well as altered diorite assaying 1,465 ppm copper and $312 \mathrm{ppm}$ nickel. The DGGS sampled a sulfide-bearing gabbro layer within the troctolite assaying $363 \mathrm{ppm}$ nickel, 444 ppm copper, $26 \mathrm{ppb}$ platinum, and 13 ppb palladium (13RN420A; Twelker and others, 2014a). A dike of leucogabbro cutting hornfels contained the most magmatic sulfide (approximately 7 percent pyrrhotite) and assayed 569 ppm copper, but contained only background concentrations of nickel, platinum, and palladium (13RN426B; Twelker and others, 2014a).

Mineral deposit model: Disseminated magmatic sulfides, possibly Norilsk-type Ni-Cu-Co-PGE (Cox and Singer, 1986; model 5b)

Alteration of deposit: Moderate serpentinization of olivine

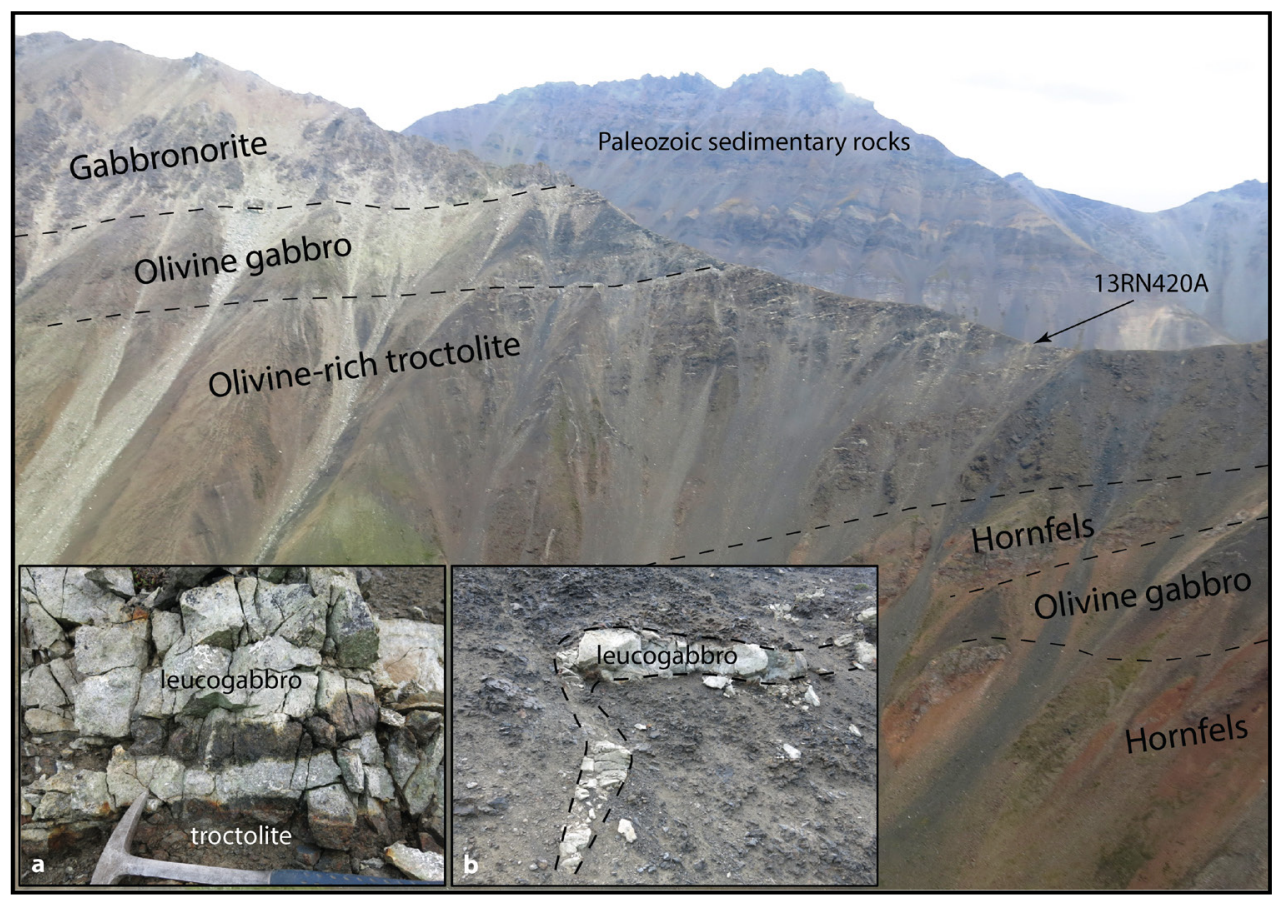

Figure A6. Oblique aerial photo of the Butte Creek intrusive complex looking southeast (see fig. 2 for location). A. (Inset) Interlayered leucogabbro and olivine-rich troctolite in the vicinity of sample 13RN420A. B. (Inset) From the same area, illustrates the dike-and-sill aspect of these bodies, which shows they are crosscutting intrusions rather than magmatic layers. 


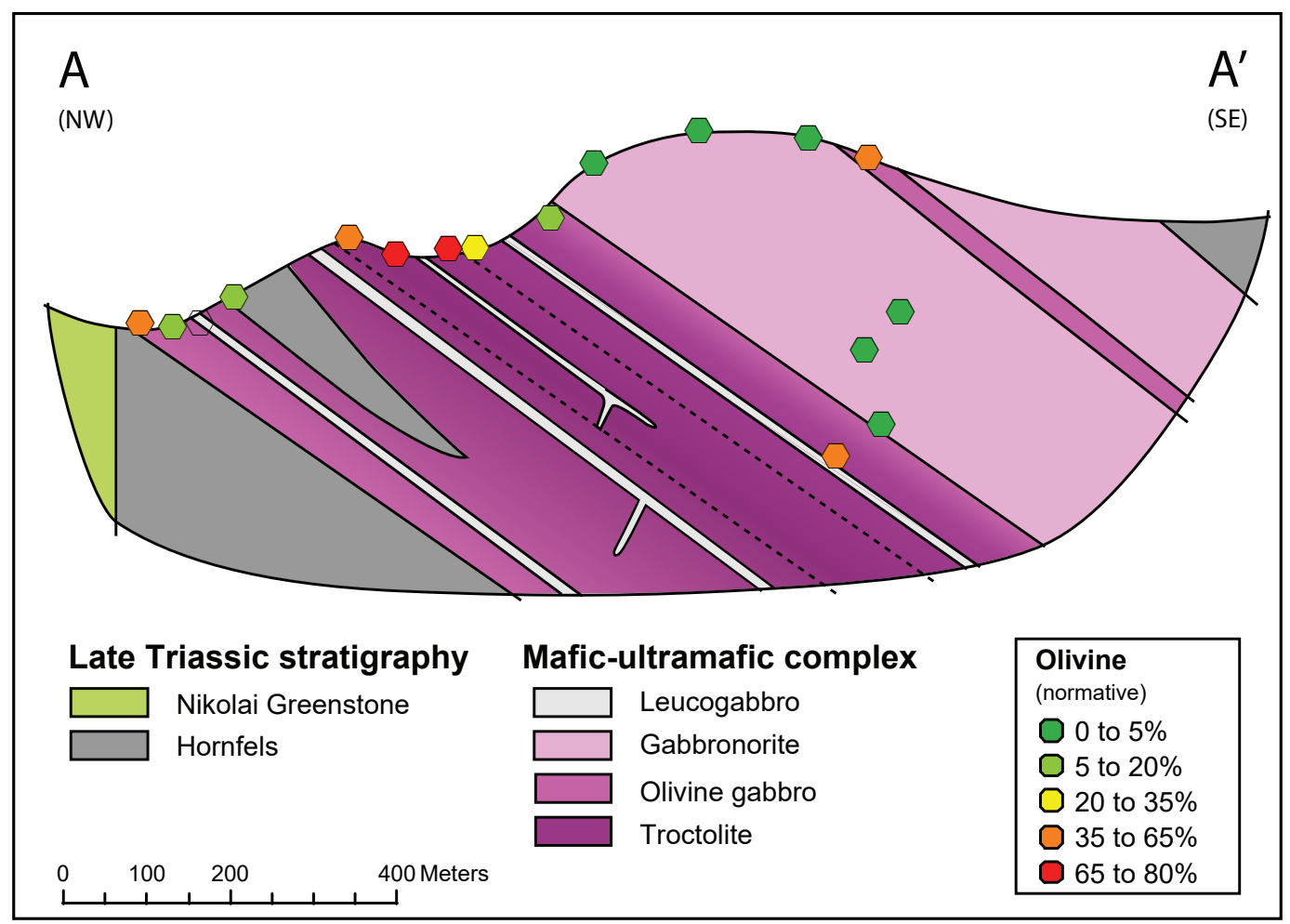

Figure A7. Schematic cross section of the Butte Creek intrusive complex at Peak 5532 (see fig. 2 for location); view to the northeast (Twelker and others, 2014b). Location of complex is shown in figure 1. Colored symbols represent samples collected on two traverses and projected to section; normative olivine was determined using XRF analysis of 37-mm-diameter rock slabs under vacuum at the University of Alaska Fairbanks.

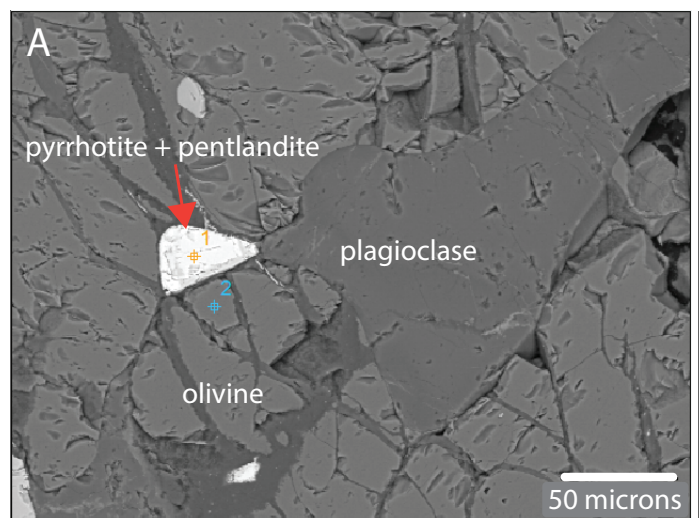

Figure A8. Backscattered electron images of magmatic sulfide grains in sample 13RN423A. A. Intergrown pyrrhotite and pentlandite at grain boundaries in olivine cumulate troctolite near the center of the Butte Creek complex. B. Spherical grain of intergrown pyrrhotite and pentlandite within cumulate olivine that we interpret as a magmatic sulfide melt inclusion. The magnetite is likely the result of alteration (Twelker and others, 2014b). See fig. 2 for the Butte Creek prospect location.
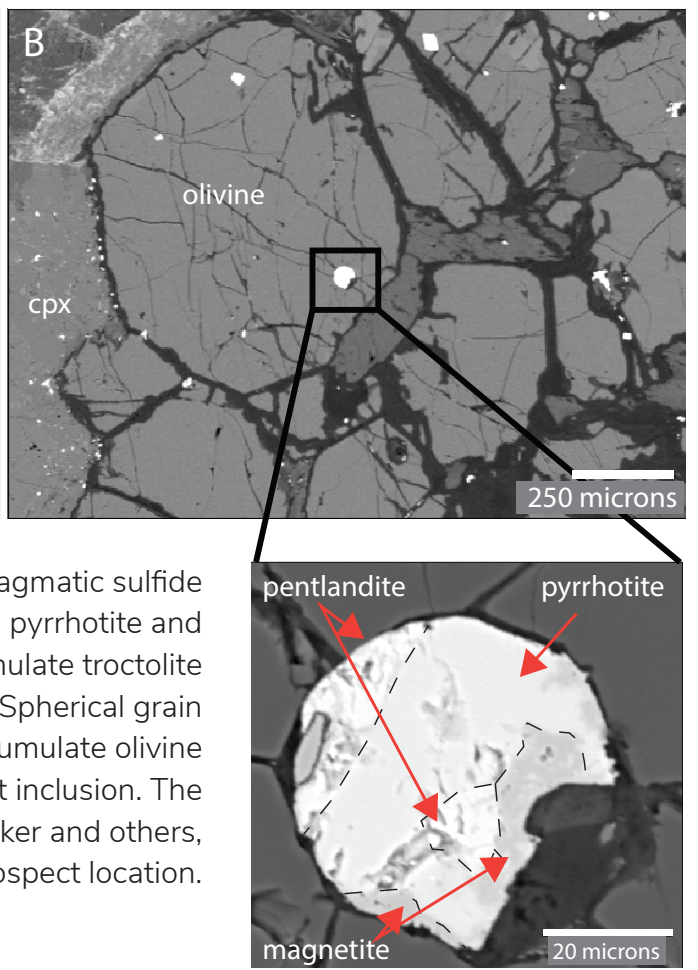
Age of mineralization: Late Triassic, based on an ${ }^{40} \mathrm{Ar} /{ }^{39} \mathrm{Ar}$ plateau age of $225.8 \pm 1.1 \mathrm{Ma}$ determined for magmatic phlogopite (Benowitz and others, 2014).

Exploration history: The occurrence was first documented during regional reconnaissance by the U.S. Bureau of Mines in the late 1980's (Balen, 1990; Kurtak and others, 1991).

In 2011, MMG USA Exploration LLC staked the Butte Creek intrusive complex and conducted exploration through 2014, after which the claims were allowed to lapse. Exploration work included geologic mapping, sampling, a helicopter-borne time-domain electromagnetic and magnetic geophysical survey, and several diamond drill holes. These holes were drilled within the broader claim block and not necessarily at the specific location of this occurrence.

\section{Eureka zone (Alpha complex)}

\section{ARDF no.: $\mathrm{MH} 388$}

Latitude and longitude: $63.2569 \mathrm{~N}, 146.2103 \mathrm{~W}$

Location: The prospect is a northwest-trending zone approximately $15 \mathrm{~km}$ long and $200 \mathrm{~m}$ thick, extending from the end moraine of the Eureka Glacier to VABM Wild in the Mount Hayes B-5 and A-5 quadrangles. The approximate midpoint is in the NE1/4 of sec. 22, T 19 S, R 8 E, Fairbanks Meridian. The latitude and longitude coordinates are the collar location of centrally located drill hole PNI-12-063.

Main commodities: $\mathrm{Ni}, \mathrm{Cu}, \mathrm{Pd}, \mathrm{Pt}$

Other commodities: $\mathrm{Co}, \mathrm{Au}, \mathrm{Ag}$

Ore minerals: Pyrrhotite, pentlandite, chalcopyrite, chromite

Geologic description: The Eureka zone is a 15-km-long, 200-m-thick zone of disseminated magmatic sulfide mineralization within the 33-km-long, 3-km-thick Alpha (or Fish Lake) mafic-ultramafic intrusive complex. The Eureka zone occurs near the middle of the intrusive complex and runs subparallel to its contacts; the average dip of the zone determined from drilling is 46 degrees towards the southwest.

The geology of the intrusive complex has previously been shown as a cyclically alternating series of ultramafic rocks and gabbros (for example, mapping of Nevada Star Resource Company and Geological Survey of Canada staff, generalized in Schmidt and Rogers, 2007); however, this interpretation is apparently based on geophysical interpretation and does not bear out in the field or in drilling.

Lande (2016) completed detailed mapping (figs. 12, A9) and analytical work on the Alpha complex, focusing on a well-exposed area around VABM Wild, located $2 \mathrm{~km}$ west of Fish Lake and $5 \mathrm{~km}$ east of the main area of the Eureka zone. Lande (2016) divides the intrusive complex into three main units: a basal ultramafic unit comprising dunite with a prominent wehrlite layer, a central feldspathic dunite unit, and an upper ultramafic unit consisting of dunite with lesser thin layers of wehrlite. Thin gabbroic dikes crosscut the ultramafic complex. Serpentinization of olivine is pervasive near the base of the complex but decreases up-dip.

Microprobe data collected along a detailed traverse through the complex (fig. A9) indicate that olivine compositions vary in concentrically zoned patterns, with olivine becoming more evolved (Fe rich) toward the center of each zone. Clinopyroxene content increases towards the center of each zone, and some of the zones are cored by wehrlite or clinopyroxenite. Lande (2016) interprets these patterns to indicate the complex is a series of individual, inwardly crystallizing sills.

The titanium ( $\mathrm{Ti}$ ) content of clinopyroxene and the $\mathrm{Mg}$, Fe, and $\mathrm{Ni}$ contents of olivine suggest that the upper ultramafic unit could have crystallized from a primitive basaltic magma similar to the low-Ti member of the Nikolai Greenstone. Mineral compositions from the feldspathic dunite unit are consistent with crystallization from a magma similar to the stratigraphically overlying high-Ti member of the Nikolai Greenstone. The basal ultramafic unit shows evidence of hybridization between the two magmas (Lande, 2016). 
A thin sliver of amphibolite-grade schist, mapped by Lande (2016) within the upper ultramafic unit (fig. 12), yielded a biotite cooling age of $33.2 \pm 0.2$ (Benowitz and others, 2017) and likely represents faultbound Maclaren schist. This observation points to additional structural complications within the Alpha complex that have not yet been sufficiently investigated.

Mineralization in the Alpha complex consists of a broad zone of approximately 2 percent disseminated sulfides occurring as irregular-shaped grains in the interstices between cumulate olivine and clinopyroxene (fig. A10A, B).

Where the zone has been altered by serpentinization, magmatic sulfide grains are surrounded and partially replaced by magnetite. Metallurgical studies indicate that a $\mathrm{Ni}$-Fe alloy, possibly awaruite, is also present as an alteration product of ore minerals (Pure Nickel Inc., 2014a).

The mineralogy of platinum-group element (PGE) mineralization in the Eureka zone is unknown; however, Kalkowski (2012) identified merenskyite, moncheite, kotulskite, sperrylite, irarsite, sobelevskite,

Figure A9. Enlargement of detailed geologic map of Lande (2016) at the Alpha ultramafic complex at the eastern end of the Eureka Zone. Points labeled

in black show microprobe olivine compositions in terms of forsterite component (Fo); dashed contour lines outline a concentric zoning pattern where individual sills are cored by more evolved (lower Fo) olivine. See figures 11 and 12 for map location and geologic legend.
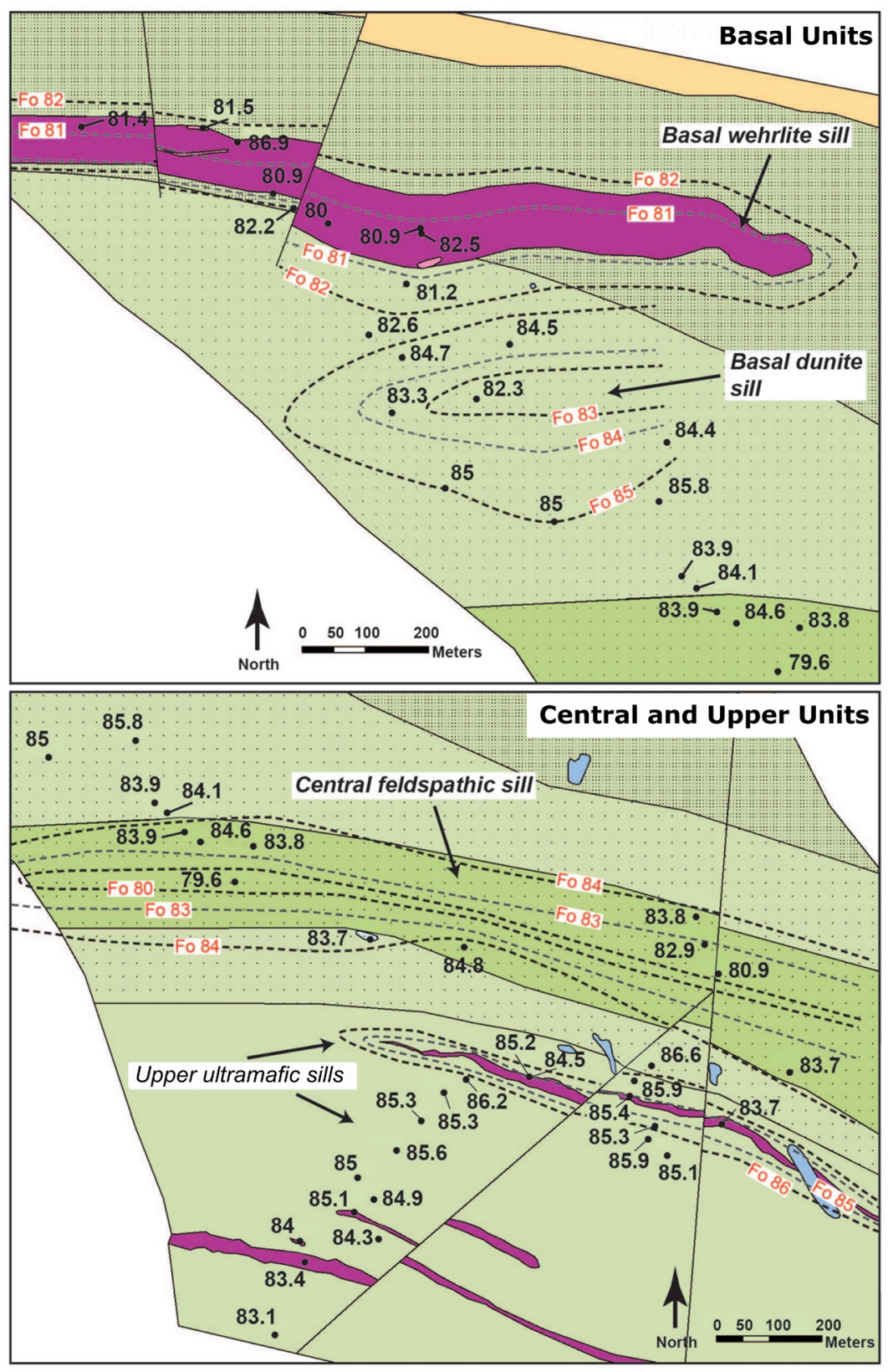
froodite, cabriite, Pt- and Pd-bearing auricupride, and tetra-auricupride in samples from other prospects in the area. Based on textural evidence and associations, he interprets the As-bearing phases (irarsite and sperrylite) to have formed during magmatic sulfide crystallization, and the $\mathrm{Sn}$-, Te-, and Bi-bearing phases to be possibly the result of post-magmatic hydrothermal processes.

The highest-grade intercept, from drill hole PNI-12-063, averaged 0.24 percent $\mathrm{Ni}, 0.15$ percent $\mathrm{Cu}$, 0.018 percent Co, $97 \mathrm{ppb}$ Pt, 156 ppb Pd, $31 \mathrm{ppb} \mathrm{Au}$, and $1.11 \mathrm{ppm}$ Ag over an estimated true thickness of $94.8 \mathrm{~m}$ (Pure Nickel Inc., 2013). A 5.7-km-long central portion of the Eureka zone, with 21 drill hole intersections, has an average thickness of approximately $200 \mathrm{~m}$, and a weighted average grade of 0.23 percent Ni, 0.08 percent $\mathrm{Cu}, 0.02$ percent $\mathrm{Co}, 170 \mathrm{ppb}$ total combined $\mathrm{Au}, \mathrm{Pt}$, and $\mathrm{Pd}$, and $0.51 \mathrm{ppm} \mathrm{Ag}$ (Pure Nickel Inc., 2014a). The average Pt/Pd ratio for Eureka zone intercepts is consistently around 0.5 (range 0.42-0.62), except for three westernmost holes, which average a Pt/Pd ratio of 1.5.

A 2013 nickel deportment study contracted by Pure Nickel to SGS Minerals Services indicates that 63 percent of total $\mathrm{Ni}$ occurs as $\mathrm{Ni}$-Fe sulfides, with 12.3 percent occurring as $\mathrm{Ni}$-Fe alloys. Twenty percent of the Ni occurs in the silicate minerals olivine and serpentine. The study was based on scanning electron microscopy (QEMSCAN) and other analyses of coarse reject material from a 134-m-long partial intersection of the Eureka zone in hole PNI-13-069 (Pure Nickel Inc., 2014a).

Mineral deposit model: Disseminated magmatic sulfides, possibly Norilsk-type Ni-Cu-Co-PGE (Cox and Singer, 1986; model 5b)

Alteration of deposit: The prospect is variably serpentinized, resulting in partial to pervasive serpentinization of olivine and partial replacement of iron and nickel sulfides by magnetite and ironnickel alloy.

Age of mineralization: The host rocks of this occurrence are cogenetic with the Nikolai Greenstone magmatic episode that formed between 230 and $225 \mathrm{Ma}$ (Greene and others, 2010).

Exploration history: Adapted from Alaska Resource Data File record by V.C. Zinno, Alaska Earth Sciences Inc.:

From 1991 to 1997, this area was explored by American Copper and Nickel Company (ACNC) working with Fort Knox Gold Resources, Inc. Their work included drilling, surface-based time-domain electromagnetic (EM) surveys (UTEM method), and borehole-based EM on three holes. From 1997 to 2003, the area was explored by Nevada Star Resource Corp. (US), whose work included a geological mapping program in addition to an airborne EM survey over the northern and southern portions of the MAN Project area. From 2004 to 2005, the area was briefly explored by Anglo American Exploration (USA). Their work included geological mapping, prospecting, and a soil geochemical sampling survey (Pure Nickel Inc., 2014b).

In 2005, Nevada Star Resource Corp. resumed work and completed a 35-line-km time-domain EM (TEM) survey over four loop areas, a 177-line-km ground magnetometer survey, and 1,057 soil samples over the general MAN Project area, including eight diamond drill holes in the Alpha complex, which is in the central part of the property. Alpha is a prospect area within the MAN Project area (Pure Nickel Inc., 2014b).

In 2007, Pure Nickel gained control of the claims and explored under a joint venture partnership with ITOCHU Corp. of Japan from 2008 to 2013. During this partnership, approximately 23.5 million U.S. dollars were spent on exploration at the general MAN Project area (Pure Nickel Inc., 2014b).

In 2011, Pure Nickel completed exploration work focused on the Alph a complex. Evaluation of the Alpha complex focused on its potential to host "reef"-type PGE mineralization typical of layered mafic intrusive complexes (e.g., Merensky Reef PGE; Cox and Singer, 1986); this exploration model is consistent with the geologic model for the Alph a complex developed by industry and described in Schmidt and Rogers (2007). 
The possible presence of this type of mineralization was inferred from the occurrence of highly anomalous $P G E$ values associated with a distinctive gabbro/pyroxenite sequence interpreted as discrete layers in the complex. Three holes targeting the potential "reef" successfully intersected the correct lithological sequence, but assay results did not confirm the presence of economic concentrations of PGE (Findlay, 2013).

In 2012, Pure Nickel completed detailed mapping, and soil and IP surveys at the Alpha complex. Follow-up drilling tested the soil and IP anomalies and resulted in the recognition of the Eureka zone in hole PNI-12063 (Findlay, 2013).

In 2013, Pure Nickel completed an exploration program that included an eight-hole, 2,991-m drill program primarily targeting the Eureka zone in the central part of the Alpha mafic-ultramafic complex. The drill program successfully intersected the Eureka zone with six of the holes from 2013 (Pure Nickel Inc., 2014b).
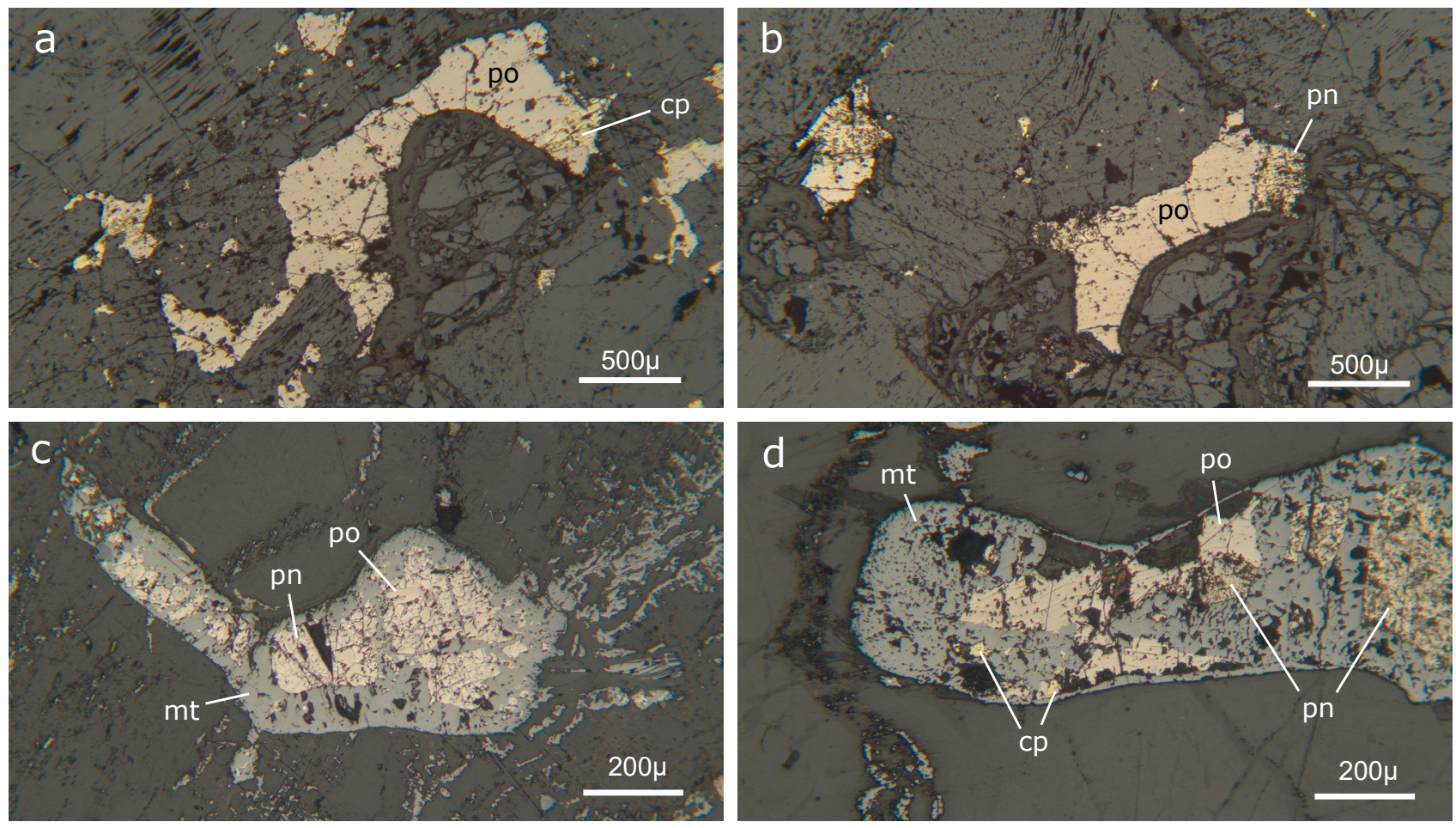

Figure A10. Photomicrographs (reflected light) of mineralization at the Eureka zone of the Alpha complex. A, B. Magmatic sulfide (pyrrhotite [po], pentlandite [pn], minor chalcopyrite [cp]) aggregates at grain boundaries between cumulate olivine and clinopyroxene (drill hole PNI-12-63 at $123.51 \mathrm{~m}$ ). C. Magmatic sulfide partially replaced by magnetite (mt) in serpentinized dunite (drill hole PNI-12-63 at 154.19 m). D. Magmatic pyrrhotite, pentlandite, and chalcopyrite partially replaced by magnetite (drill hole PNI-12-63 at 214.59 m). See figures 2 and 31 for the Eureka zone location. 